\title{
Evaluation of Sites for Advanced Reactor Demonstrations at Idaho National Laboratory
}

\section{March 2020}

\begin{abstract}
Alison Conner - Systems Methods \& Analysis George Griffith - Systems Integration Mike W. Patterson - Fuel Cycle Science \& Technology

Contributors

Jason Andrus - Advanced Nuclear Facility Safety Engineering Louis Guillen - Facility Design \& Project Engineering Helen Guymon - Project Management Office Project Managers Randy Lee - Office of Campus Planning \& Space Management Sal Mascarenas - Project Management Office Project Managers Troy Reiss - Advanced Nuclear Facility Safety Engineering
\end{abstract}

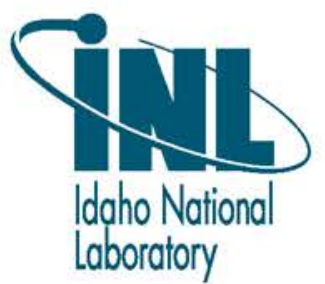




\section{DISCLAIMER}

This information was prepared as an account of work sponsored by an agency of the U.S. Government. Neither the U.S. Government nor any agency thereof, nor any of their employees, makes any warranty, expressed or implied, or assumes any legal liability or responsibility for the accuracy, completeness, or usefulness, of any information, apparatus, product, or process disclosed, or represents that its use would not infringe privately owned rights. References herein to any specific commercial product, process, or service by trade name, trademark, manufacturer, or otherwise, does not necessarily constitute or imply its endorsement, recommendation, or favoring by the U.S. Government or any agency thereof. The views and opinions of authors expressed herein do not necessarily state or reflect those of the U.S. Government or any agency thereof. 


\title{
Evaluation of Sites for Advanced Reactor Demonstrations at Idaho National Laboratory
}

\author{
Alison Conner - Systems Methods \& Analysis \\ George Griffith - Systems Integration \\ Mike W. Patterson - Fuel Cycle Science \& Technology
}

Contributors

Jason Andrus - Advanced Nuclear Facility Safety Engineering

Louis Guillen - Facility Design \& Project Engineering

Helen Guymon - Project Management Office Project Managers Randy Lee - Office of Campus Planning \& Space Management Sal Mascarenas - Project Management Office Project Managers

Troy Reiss - Advanced Nuclear Facility Safety Engineering

March 2020

Idaho National Laboratory

Idaho Falls, Idaho 83415

http://www.inl.gov

Prepared for the

U.S. Department of Energy

Office of Nuclear Energy

Under DOE Idaho Operations Office

Contract DE-AC07-05ID14517 
Page intentionally left blank 


\section{SUMMARY}

The development, demonstration and deployment of advanced reactors are becoming of increasing interest in the U.S. to provide a clean, reliable, and safe source of energy. In general, advanced reactors are those reactors that are based on technologies that are not currently deployed commercially and includes a range of reactor concepts and sizes. Of particular interest in the near term are demonstrations of microreactors, which are small reactor with power levels less than $20 \mathrm{MW}$ and are targeted for nonconventional nuclear markets including defense sites, remote communities, mining sites, and back-up generators for nuclear power plants and other sites. Such applications face economic and energy security challenges that can be uniquely addressed with these innovative nuclear reactors. Generally, advanced reactors are differentiated from other classes of reactors by features such as factory manufacturability; transportability by truck, rail or aircraft; and simplicity of design features, particularly those related to reactor control and safety.

On August 15, 2019, DOE announced the launch of the National Reactor Innovation Center (NRIC). NRIC, led by INL, is authorized by the Nuclear Energy Innovation Capabilities Act (NEICA) to provide private sector technology developers access to the strategic infrastructures and assets of the national laboratories. NRIC plans to support demonstrations of microreactor concepts within the next five years.

This evaluation of reactor demonstration sites identifies a list of candidate site locations or areas within INL boundaries for onsite demonstration of advanced reactors. A comparison of suitable advanced reactor sites is provided and includes evaluation of existing buildings, previously disturbed, and undisturbed locations across the INL Site.

A six-step robust process that considers the National Environmental Policy Act of 1969 (NEPA), NRC licensing, and DOE regulations was utilized to evaluate potential sites and is defined as follows:

1. Identify siting criteria (both "Must" and "Want")

2. Identify candidate sites

3. Apply "Must" screening criteria to all candidate sites

4. Evaluate remaining candidate sites against "Want" criteria

5. Rank candidate sites

6. Recommend the most suitable site(s).

Thirty-two candidate sites across INL were included in this analysis. Nine of the 32 sites failed the "Must" criteria screening step, leaving 23 sites to evaluate.

Based on this analysis, it is recommended that advanced reactor demonstrations at INL consider utilizing one of the following preferred locations, listed from highest to lowest evaluation score supplemented with consideration of the specific characteristics of the demonstration, such as preferences for use of existing facilities, undeveloped sites, etc.:

- $\quad$ Site \#2 - MFC-767 (EBR-II) 
- $\quad$ Site \#3 - MFC-775/776 (ZPPR)

- $\quad$ Site \#1 - CPP-691 (FPR)

- Site \#10 - Undeveloped area north of MFC

- $\quad$ Site \#9 - Undeveloped area west of MFC

- Site \#11 - Undeveloped area east of MFC

- Site \#8 - Undeveloped area west of the ATR Complex

- Site \#6 - Previously developed area west of CFA

- Site \#32 - Previously developed area east of CFA.

One option to consider to streamline adoption of these sites is to obtain an NRC Early Site Permit (ESP). An ESP requires Senior Seismic Hazard Analysis Committee (SSHAC) Level 3 compliant site-characterization data, which currently exists for some of these candidate sites. However, an ESP can be expeditiously developed for one or more of these sites with existing data. Additional sites could be added if identified and seismic characterization is funded by Spring 2020. The next opportunity for including additional undeveloped sites to the list of preferred siting options will occur after the completion of the current SSHAC Level 3 analysis, tentatively planned to complete in February 2022.

The preferred sites listed above, and available site characterization data will be made available to developers granted INL use permits by DOE. Final selection of a reactor demonstration site for a specific advanced reactor will be made in consultation with DOE and in accordance with the site selection process established in the applicable authorized INL use agreement. 
Page intentionally left blank 


\section{CONTENTS}

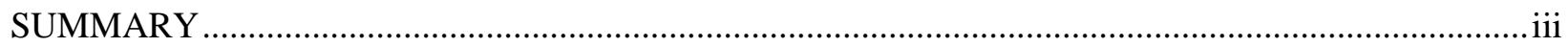

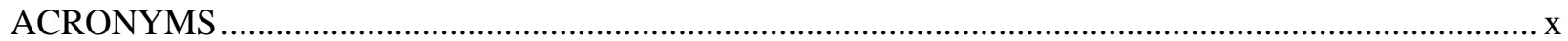

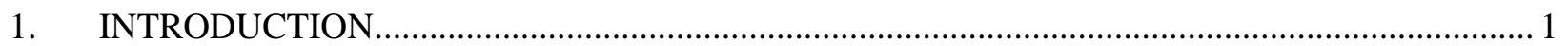

1.1 Purpose

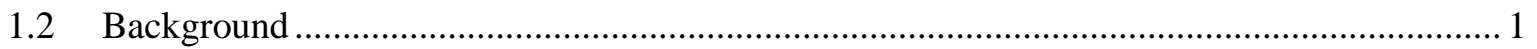

1.3 Senior Seismic Hazard Analysis Committee (SSHAC) Level 3 Analysis ............................... 3

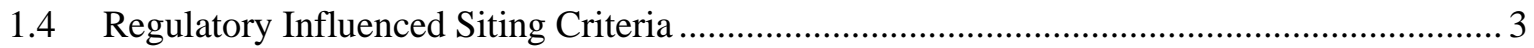

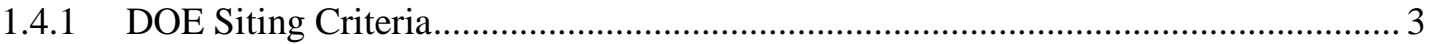

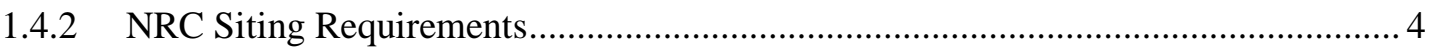

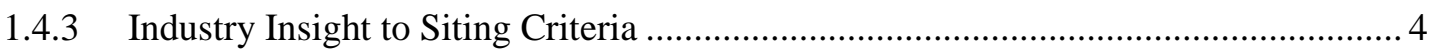

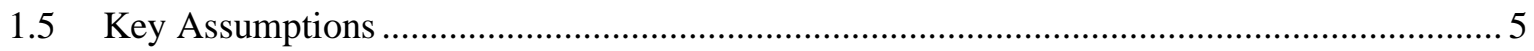

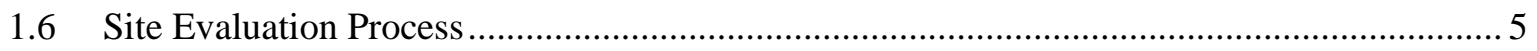

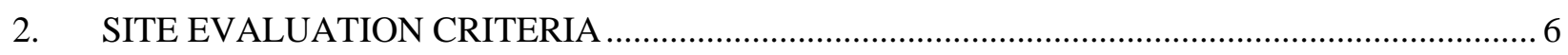

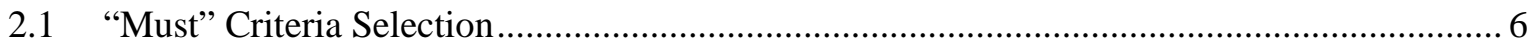

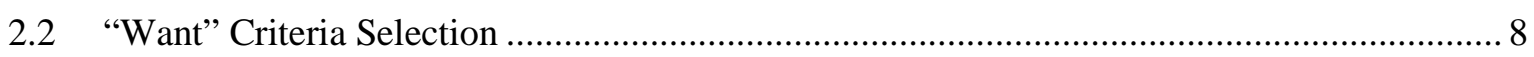

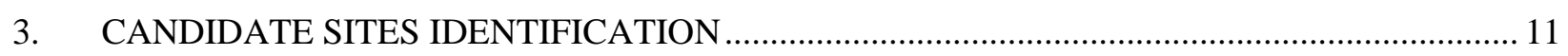

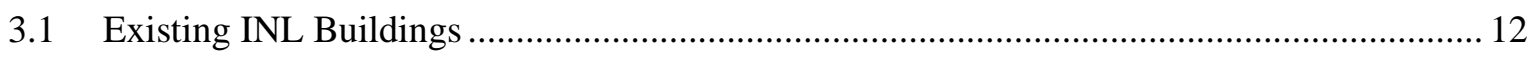

3.1.1 CPP-691 Fuel Process Restoration (FPR) Project Facility (Location 1) .................. 12

3.1.2 MFC-767 (EBR-II) Plant Building (Location 2) ................................................... 12

3.1.3 MFC-775 and MFC-776 (ZPPR) Reactor Buildings (Location 3) ........................... 13

3.1.4 PBF-612 (CITRC) Control System Research Facility (Location 4) ........................... 14

3.1.5 PBF-613 (CITRC) Communications Research Facility (Location 5) ........................ 14

3.2 Previously Developed Sites.......................................................................................... 15

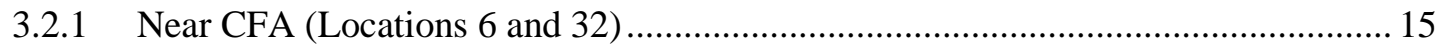

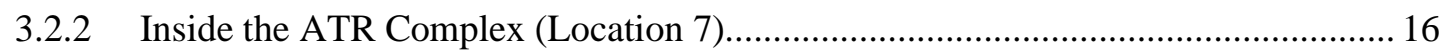

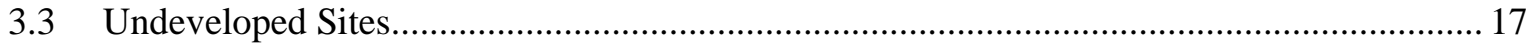

3.3.1 Near the ATR Complex (Location 8)..................................................................... 18

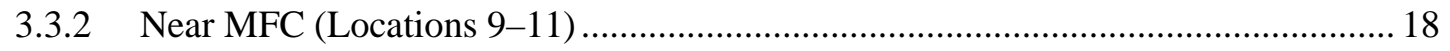

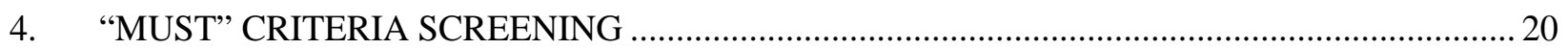

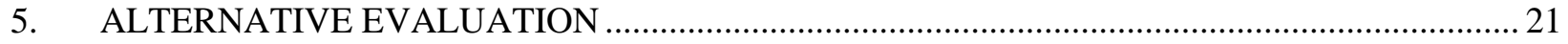

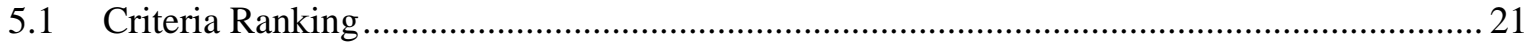

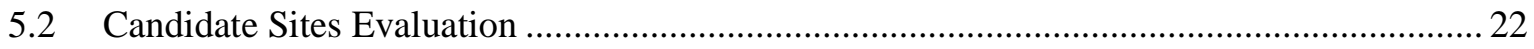

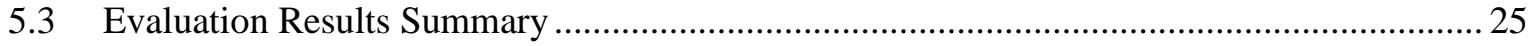

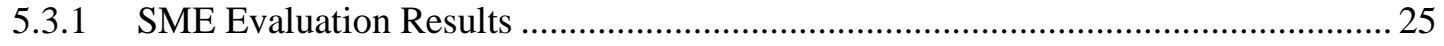

5.3.2 Noted Structural Challenges with Existing Building Preferred Sites ........................ 25 


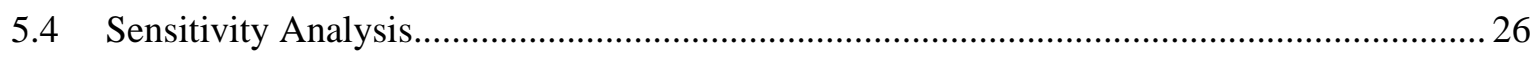

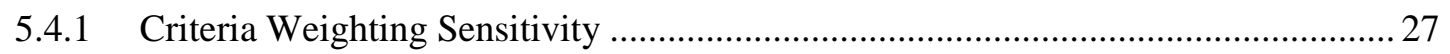

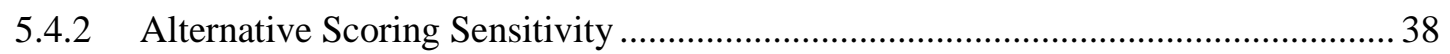

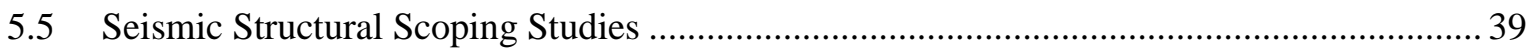

5.5.1 CPP-691 (FPR) Seismic Structural Scoping Study.................................................... 40

5.5.2 MFC-767 (EBR-II) Seismic Structural Scoping Study .............................................. 40

5.5.3 MFC-775/776 (ZPPR) Seismic Structural Scoping Study ........................................ 41

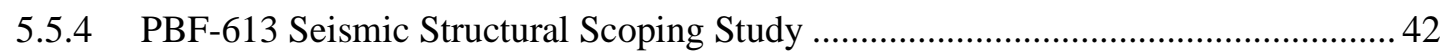

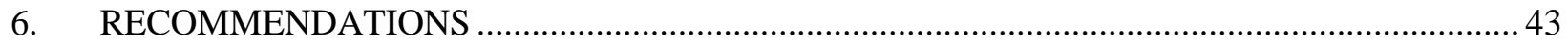

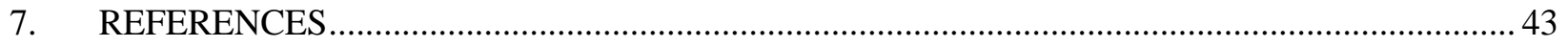

Appendix A Candidate Site Descriptions and Scoring Explanations ..................................................... 47

Appendix B SME Evaluation Meetings - Documentation .................................................................... 54

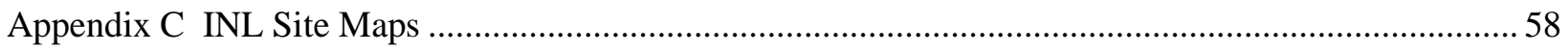

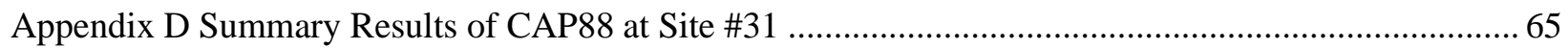

\section{FIGURES}

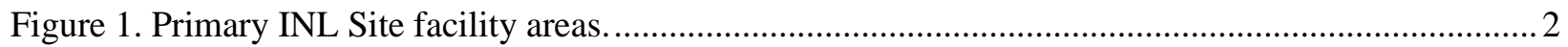

Figure 2. INL institutionally controlled areas................................................................................... 8

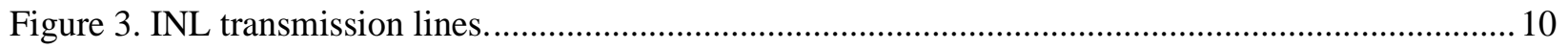

Figure 4. Candidate advanced reactor site locations................................................................................ 11

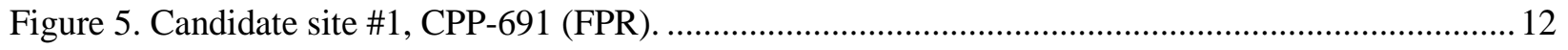

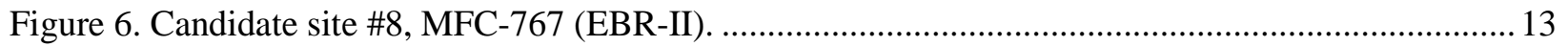

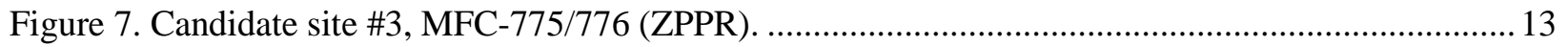

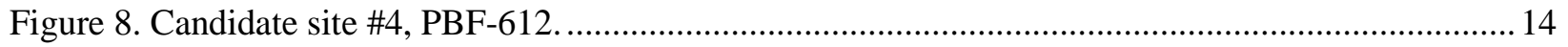

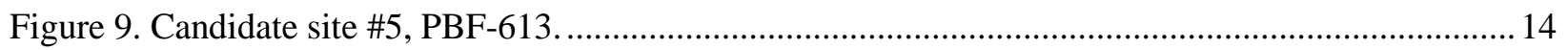

Figure 10. Proposed previously developed sites near CFA. …............................................................... 15

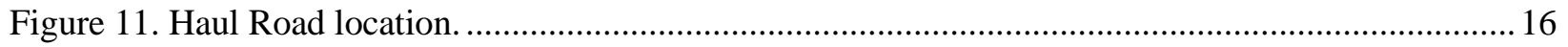

Figure 12. Proposed previously developed site inside the ATR Complex................................................. 17

Figure 13. Proposed undeveloped site adjacent to the ATR Complex..................................................... 18

Figure 14. Proposed undeveloped sites around MFC (siting locations \#9, \#10, and \#11) in reference to proposed existing building sites (siting locations \#2 and \#3)............................... 19

Figure 15. Remaining candidate advanced reactor sites......................................................................... 21

Figure 16. “Avoid areas of surface water flooding/ponding” criterion weight sensitivity with transition points identified relative to assigned weight setting. 28

Figure 17. "Maximize proximity to suitable sources of cooling water" criterion weight sensitivity with transition points identified relative to assigned weight setting. 
Figure 18. "Minimize disturbance of critical habitat of protected species" criterion weight sensitivity with transition points identified relative to assigned weight setting.

Figure 19. "Avoid areas of high predictive archaeology zones” criterion weight sensitivity with transition points identified relative to assigned weight setting.

Figure 20. "Minimize potential adverse interactions with existing programs" criterion weight sensitivity with transition points identified relative to assigned weight setting.

Figure 21. "Ensure appropriate security controls are available” criterion weight sensitivity with transition points identified relative to assigned weight setting.

Figure 22. "Minimize distance from transportation routes" criterion weight sensitivity with transition points identified relative to assigned weight setting.

Figure 23. "Minimize distance to transmission lines" criterion weight sensitivity with transition points identified relative to assigned weight setting. 35

Figure 24. "Optimize use of Land Use planning zones" criterion weight sensitivity with transition points identified relative to assigned weight setting.

Figure 25. "Maximize use of updated seismic hazard analysis and site-specific characterization data" criterion weight sensitivity with transition points identified relative to assigned weight setting. 37

Figure 26. "Minimize proximity to faults and building on soil sites" criterion weight sensitivity with transition points identified relative to assigned weight setting. 38

Figure 27. Alternative scoring sensitivity analysis.

\section{TABLES}

Table 1. Scoring criteria category definitions................................................................................... 5

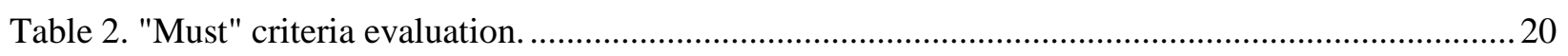

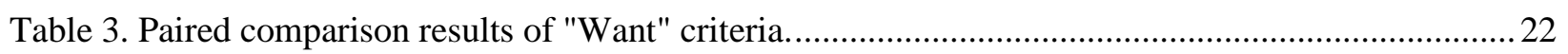

Table 4. Summary evaluation matrix of preferred candidate sites - existing buildings............................. 23

Table 5. Summary evaluation matrix of preferred candidate sites - undeveloped sites.............................24

Table 6. Summary evaluation matrix of preferred candidate sites - previously developed sites................24

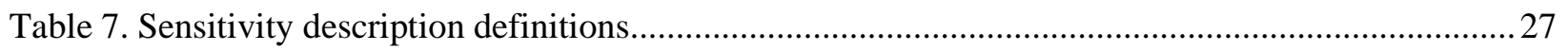


Page intentionally left blank 


\section{ACRONYMS}

ATR Advanced Test Reactor

BEA Battelle Energy Alliance, LLC

CAP88 Clean Air Act Assessment Package-88

CERCLA Comprehensive Environmental Response, Compensation, and Liability Act

CFA Central Facilities Area

CFPP Carbon Free Power Project

CITRC Critical Infrastructure Test Range Complex

CPP Chemical Processing Plant (formerly ICPP, now INTEC)

DBT Design Basis Threat

DCR Demand/Capacity Ratio

DNFSB Defense Nuclear Facilities Safety Board

DOE Department of Energy

DOE-EM Department of Energy Office of Environmental Management

DOE-ID Department of Energy Idaho Operations Office

DOE-NE Department of Energy Office of Nuclear Energy

EBR-II Experimental Breeder Reactor II

EPA Environmental Protection Agency

EPRI Electric Power Research Institute

ESP Early Site Permit

FPR Fuel Processing Restoration

GDC general design criteria

HALEU high-assay low-enriched uranium ( $>5 \%$ and $<20 \%$ 235U)

INL Idaho National Laboratory

INTEC Idaho Nuclear Technology and Engineering Center (formerly ICPP)

MFC Materials and Fuels Complex

NEICA Nuclear Energy Innovation Capabilities Act

NEPA National Environmental Policy Act of 1969

$\mathrm{NPH}$ natural phenomena hazard

NQA Nuclear Quality Assurance

NRC Nuclear Regulatory Commission

NRIC National Reactor Innovation Center

NRF Naval Reactors Facility 


$\begin{array}{ll}\text { PaR } & \text { PaR Systems Corporation (remote equipment) } \\ \text { PBF } & \text { Power Burst Facility } \\ \text { PC } & \text { performance category } \\ \text { PSHA } & \text { probabilistic seismic hazard analysis } \\ \text { RWMC } & \text { Radioactive Waste Management Complex } \\ \text { SGH } & \text { Simpson Gumpertz \& Heger, Inc. } \\ \text { SMC } & \text { Specific Manufacturing Capability } \\ \text { SME } & \text { subject matter expert } \\ \text { SNM } & \text { special nuclear material } \\ \text { SPERT } & \text { Special Power Excursion Reactor Tests } \\ \text { SSCs } & \text { structures, systems, or components } \\ \text { SSHAC } & \text { Senior Seismic Hazard Analysis Committee } \\ \text { TAN } & \text { Test Area North } \\ \text { UAMPS } & \text { Utah Associated Municipal Power Systems } \\ \text { USGS } & \text { U.S. Geological Survey } \\ \text { ZPPR } & \text { Zero Power Physics Reactor }\end{array}$


Page intentionally left blank 


\section{Evaluation of Sites for Advanced Reactor Demonstrations at Idaho National Laboratory \\ 1. INTRODUCTION}

The development, demonstration and deployment of advanced reactors are becoming of increasing interest in the U.S. to provide a clean, reliable, and safe source of energy. In general, advanced reactors are those reactors that are based on technologies that are not currently deployed commercially and includes a range of reactor concepts and sizes. Of particular interest in the near term are demonstrations of microreactors, which are small reactor with power levels less than $20 \mathrm{MW}$ and are targeted for nonconventional nuclear markets including defense sites, remote communities, mining sites, and back-up generators for nuclear power plants and other sites. Such applications face economic and energy security challenges that can be uniquely addressed with these innovative nuclear reactors. Generally, advanced reactors are differentiated from other classes of reactors by features such as factory manufacturability; transportability by truck, rail or aircraft; and simplicity of design features, particularly those related to reactor control and safety.

On August 15, 2019, DOE announced the launch of the National Reactor Innovation Center (NRIC). NRIC, led by INL, is authorized by the Nuclear Energy Innovation Capabilities Act (NEICA) to provide private sector technology developers access to the strategic infrastructures and assets of the national laboratories. NRIC plans to support demonstrations of microreactor concepts within the next five years. (Office of Nuclear Energy 2019).

\subsection{Purpose}

This siting evaluation identifies a list of candidate site locations or areas within INL boundaries for onsite demonstration of advanced reactors. A comparison of suitable advanced reactor sites is provided and includes evaluation of existing buildings, previously developed sites, and undeveloped sites across the INL Site.

The information needed to evaluate potential sites at this initial stage of site selection is assumed to be limited to information that is obtainable from published reports, public records, public and private agencies, and individuals knowledgeable about the locality of a potential site (NRC 2014).

This study identifies regulatory requirements that may be applicable to siting such a facility or are useful in determining specific evaluation criteria. The candidate sites were evaluated and ranked per their

ability to meet DOE and NRC siting criteria for advanced reactors. The evaluation took into consideration how well a candidate site met each of the siting criteria with the understanding that a site may exceed some criteria and not fully meet others. Use was made of previous siting studies to take advantage of available INL knowledge.

\subsection{Background}

In operation since 1949, the INL Site is a DOE reservation located in the southeastern Idaho desert, approximately 25 miles west of Idaho Falls and approximately 890 square miles (569,135 acres) in size.

The major facilities at the INL Site are the Advanced Test Reactor (ATR) Complex; Central Facilities Area (CFA); Critical Infrastructure Test Range Complex (CITRC); Idaho Nuclear Technology and Engineering Center (INTEC); Materials and Fuels Complex (MFC); Naval Reactors Facility (NRF); Radioactive Waste Management Complex (RWMC) managed and operated by Fluor Idaho; and Test Area North (TAN), which includes the Specific Manufacturing Capability (SMC) (Figure 1) (DOE-ID 2016a). 


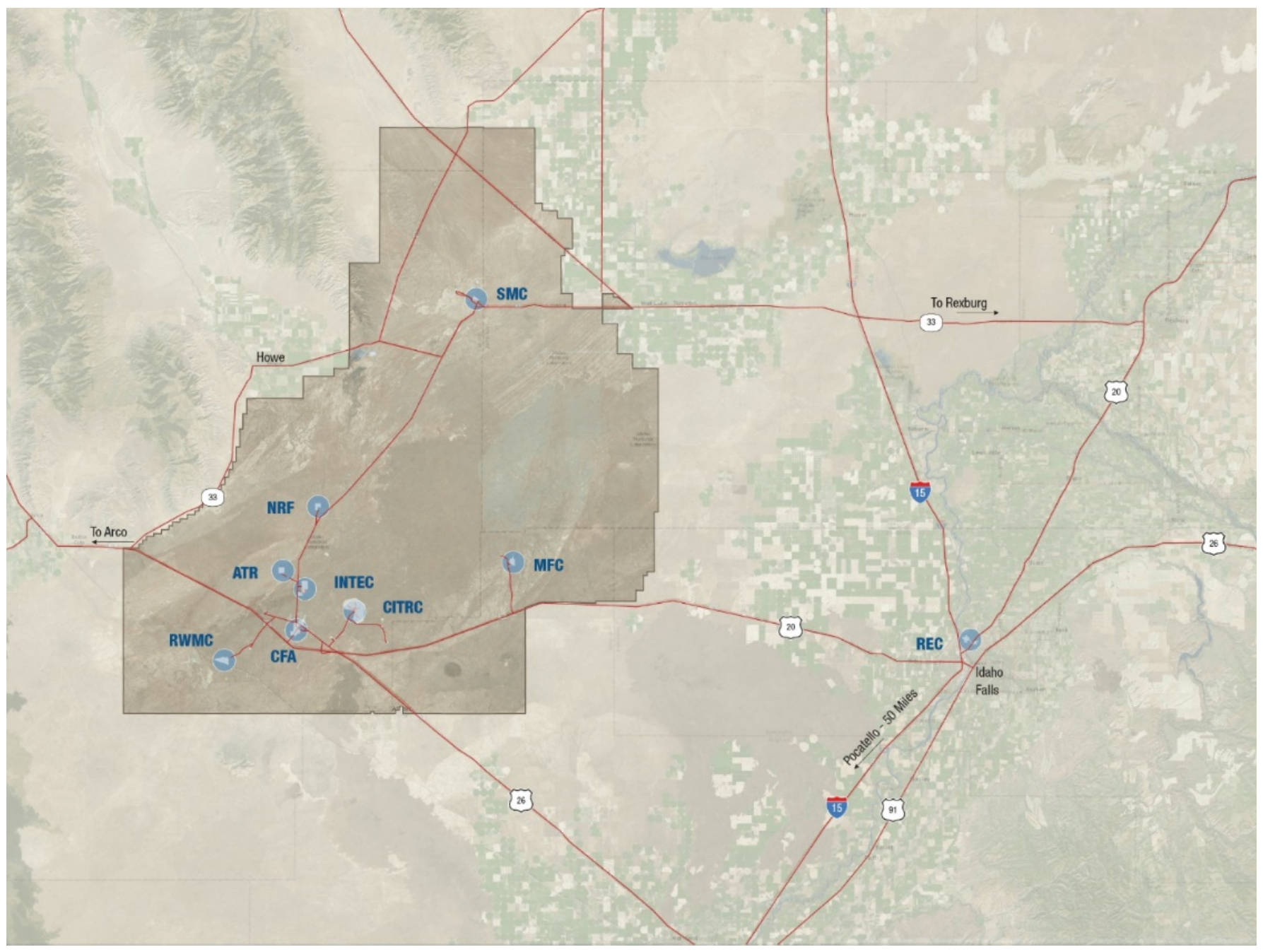

Figure 1. Primary INL Site facility areas. 


\subsection{Senior Seismic Hazard Analysis Committee (SSHAC) Level 3 Analysis}

INL last completed a probabilistic seismic hazard analysis (PSHA) in 1996 that, with updated computations in 2000, currently supports the seismic safety basis of existing INL nuclear facilities classified as Seismic Design Category-3 and above. The initial 1996 PSHA was not conducted under the SSHAC framework since it predates the development of NRC's SSHAC guidance, thus it cannot be used to support the design of new nuclear facilities. INL recently completed a SSHAC Level 1 study (INL 2019a) at three INL sites (ATR, MFC, and NRF), which identified key seismic hazard issues and provided a starting point for the INL Sitewide SSHAC Level 3 study. The tentatively planned completion date for the SSHAC Level 3 analysis is February 2022 (Payne 2019).

The key outcomes of the SSHAC Level 3 analysis that are relevant to the advanced reactor siting study and future siting studies include the following:

- Establishment of the INL PSHA

- Identification of the general INL Site upgrade that is a long lead item in reactor deployment

- Completion of an NRC-approved seismic evaluation

- Creation of Nuclear Quality Assurance (NQA)-1 data from diverse geologic data

- Enablement of lower level updates for follow up analysis.

\subsection{Regulatory Influenced Siting Criteria}

Potential projects currently being evaluated for demonstration on the INL Site include DOE, and NRC regulated advanced reactors. The siting needs, known to date, for these types of regulated advanced reactors are listed below.

\subsubsection{DOE Siting Criteria}

Per DOE O 420.1C and DOE G 420.1-1A, designers are required to choose appropriate site locations for new and modified nuclear facilities. The following factors should be considered in determining facility site suitability:

- Site boundary and land-use characteristics of the site surroundings, including properties at risk from accidental exposures, public exclusion zones (access control), population center distances, and population density

- Site physical characteristics, including topography, meteorology, and hydrology

- Geological and subsurface elements, such as the potential for fault rupture and the severity of vibratory ground motions from earthquakes, soil bearing design capacity, rock or other bearing stratum, ground settlement, and groundwater elevations

- Natural phenomena hazards (NPHs) as discussed in Attachment 2, Chapter IV of DOE O 420.1C, including earthquakes, volcanic ejection, wind, flood, snow, hail, precipitation, and lightning

- Utility systems essential to support safety class SSCs, such as electrical power supply and water supply

- Proximity of services, such as fire department and emergency medical centers

- Emergency response considerations, including population sheltering or shielding parameters and evacuation delay times and rates for the public and collocated workers 
- Potential human-induced hazards from nearby facilities or activities, such as industrial and military facilities (including other DOE facilities), aircraft impacts, pipelines, and transportation routes

- Proximity of nearby facilities and hazards both to and from the proposed facility

- Site-related assumptions of the related environmental impact statement.

\subsubsection{NRC Siting Requirements}

Below is the list of applicable NRC regulations.

10 CFR Part 50, “Domestic Licensing of Production and Utilization Facilities,” governs the licensing of nuclear power plants. Appendix A to Part 50 provides general design criteria (GDC). Criterion 2 (GDC 2), "Design Bases for Protection Against Natural Phenomena," requires structures important to safety be designed to withstand the effects of expected natural phenomena when combined with the effects of normal accident conditions without loss of capability to perform their safety function.

10 CFR Part 51, “Environmental Protection Regulations for Domestic Licensing and Related Regulatory Functions,” provides regulations applicable to NRC's preparation and processing of environmental impact statements and related documents pursuant to Section 102(2)(C) of NEPA.

10 CFR Part 52 "Licenses, Certifications, and Approvals for Nuclear Power Plants," governs the issuance of early site permits, standard design certifications, combined licenses, standard design approvals, and manufacturing licenses for nuclear power facilities licensed under Section 103 of the Atomic Energy Act of 1954, as amended (68 Stat. 919), and Title II of the Energy Reorganization Act of 1974 (88 Stat. 1242). Some of the Part 52 criteria are directly related to site characteristics, as well as to events and conditions outside the nuclear power unit.

10 CFR Part 100, “Reactor Site Criteria,” requires the NRC to consider population density; use of the site environs, including proximity to manmade hazards; and the physical characteristics of the site, including seismology, meteorology, geology, and hydrology, in determining the acceptability of a site for a nuclear power reactor. 10 CFR 100.20 provides factors to be considered, 10 CFR 100.21 provides nonseismic criteria, and 10 CFR 100.23, provides geologic and seismic criteria.

The National Environmental Policy Act of 1969 (NEPA) (42 U.S.C. 4321 et seq.), as amended, implemented by Executive Orders 11514 and 11991 and the Council on Environmental Quality's regulations (40 CFR Parts 1500-1508) requires all agencies of the federal government prepare detailed environmental statements on proposed major federal actions that will significantly affect the quality of the human environment. A principal objective of NEPA requires the federal agency to consider, in its decision-making process, the environmental impacts of each proposed major action and the available alternative actions, including alternative sites (NRC 2014)

\subsubsection{Industry Insight to Siting Criteria}

Additional siting criteria insight was provided by a potential vendor representative during a telephone conversation that their building design for housing their advanced reactor included a basement that would hold the reactor and main floor that would hold the power conversion system. They anticipate using a greenfield site to build this building and will need local potable water, sewer system, and access to INL services.

This vendor is developing a compact fast reactor which uses liquid metal heat transport. These reactors fit into a containerized system that can bring power to areas without reliable power and in some cases without power at all. Their advanced reactor design does not require cooling water since they anticipate using air cooling. 
The vendor would also like the option of selling power to the grid in which case the INL power grid might allow them to demonstrate what they need while avoiding commercial distribution of power.

\subsection{Key Assumptions}

Key assumptions applied during the siting evaluation include the following:

1. Only sites within the INL Site boundary will be evaluated.

2. Sites must be evaluated for suitability for fast and thermal reactor types.

3. Any reactor sited will be $<300 \mathrm{MW}(\mathrm{e})(<20 \mathrm{MW}(\mathrm{t})$ for microreactors).

4. Due to their small source term and inherently safe designs, the minimum area needed for construction and demonstration of a new advanced reactor design is on a 100-acre parcel, allowing for a 25-acre construction area and a one acre actual facility site.

5. Radiation shielding and containment for undeveloped and previously developed site locations is the vendor's responsibility.

6. A minimum floor loading capacity for any existing building to be considered as a potential advanced reactor demonstration site is $750 \mathrm{lbs} / \mathrm{ft}^{2}$ to enable forklift movements within the building.

\subsection{Site Evaluation Process}

While a facility site evaluation process considers many detailed and often complex criteria, it can be refined into an efficient five-step process that analyzes available data and information in a logical sequence. As presented here, the process makes extensive use of previous siting studies to take full advantage of criteria development and decision analyses or ranking strategies that have proven successful in the past. The six-step robust process that supports NEPA, NRC licensing, and DOE regulations is defined as follows:

1. Identify siting criteria (both "Must" and "Want”)

2. Identify candidate sites

3. Apply "Must" screening criteria to all candidate sites

4. Evaluate remaining candidate sites against "Want" criteria

5. Rank candidate sites and recommend the most suitable site(s).

6. Recommend the most suitable site(s).

The "Must” and "Want” criteria are defined in Table 1.

Table 1. Scoring criteria category definitions.

\begin{tabular}{ll}
\hline Criterion & Definition \\
\hline "Must" & $\begin{array}{l}\text { A critical site characteristic that is stated in measurable terms to recognize } \\
\text { when an alternative does and does not meet the criteria; if not met the } \\
\text { location is not suitable. }\end{array}$ \\
"Want" & $\begin{array}{l}\text { An important site characteristic that is desirable and may have varying } \\
\text { degrees of importance. }\end{array}$
\end{tabular}




\section{SITE EVALUATION CRITERIA}

The evaluation process for this siting study began with the review of NRC Regulatory Guide 4.7, General Site Suitability Criteria for Nuclear Power Stations, and previously performed siting studies at INL. The Carbon Free Power Project Phase II, Potential Siting Locations report, completed in January 2016, is the most recently completed siting study at INL for siting a commercial nuclear power plant. In the referenced study, the Utah Associated Municipal Power Systems (UAMPS) worked with INL to site a NuScale small modular commercial nuclear power plant, the Carbon Free Power Project (CFPP), on the INL Site. They utilized a contractor named ENERCON to perform the NRC-approved Electric Power Research Institute process (EPRI 2002), making the outcome of the ENERCON study relevant input to an advanced reactor siting study.

\section{1 "Must" Criteria Selection}

The advanced reactor siting study utilized NRC Regulatory Guide 4.7 as the starting point in identifying applicable site evaluation criteria and added INL specific criteria. Below is the list of "Must" criteria and basis for criteria selection.

"Must" Criteria:

1. Must be located $>10$ miles from an airport.

Basis: Potential hazards associated with nearby transportation routes, industrial and military facilities must be evaluated, and site characteristics established such that potential hazards from such routes and facilities will pose no undue risk to the type of facility proposed to be located at the site (NRC 2014).

2. Must be in an area of $<0.5 \mathrm{G}$ peak ground acceleration.

Basis: The physical characteristics of the site, including meteorology, geology, seismology, and hydrology must be evaluated and site characteristics established such that potential threats will pose no undue risk to the type of facility proposed to be located at the site. Peak ground acceleration (PGA) is equal to the maximum ground acceleration that occurred during earthquake shaking at a location. PGA is equal to the amplitude of the largest absolute acceleration recorded on an accelerogram at a site during an earthquake.

3. Must be located $>5$ miles from surface faults and capable tectonic structures.

Basis: Minimizing the risk from seismic events is an important consideration and is addressed by the NPH clauses in DOE Order 420.1 and DOE Guide 420.1-1. The NRC definition of a capable fault states in part that a fault is capable if there has been ground movement at or near the ground surface at least once in the past 35,000 years or movement of a recurring nature within the past 500,000 years. Based on this definition, the capable faults nearest to INL are the Howe section of the Lemhi fault, the Arco section of the Lost River fault (U.S. Geological Survey [USGS] 2006), and the Blue Dome segment of the Beaverhead fault. These faults terminate just outside the western border of INL, but if a five-mile scoring zone is considered, the zones for the Lemhi and Beaverhead faults would extend onto INL. Owing to the potential importance of minimizing risk from seismic events and the relative ease of avoiding sites near capable faults, this "Must" criterion is appropriate, and the five-mile buffer is understood to be conservative.

4. Must be located away from population centers of $>25,000$ people.

Basis: Every site must have an exclusion area and a low population zone, as defined in § 100.3; The population center distance, as defined in $\S 100.3$, must be at least one and one-third times the distance from the reactor to the outer boundary of the low population zone. 
5. Must be located $>5$ miles from hazardous sites.

Basis: The nature and proximity of man-related hazards (e.g., airports, dams, transportation routes, military, chemical facilities, and explosives test range) must be evaluated to establish site characteristics for use in determining whether a plant design can accommodate commonly occurring hazards and whether the risk of other hazards is very low. The explosives test area is included due to the importance of conforming to current and future INL land-use plans and the safety considerations associated with testing explosives. Figure 2 depicts the institutionally controlled hazardous areas at INL, including CERCLA, radioactive contamination, soil contamination, and previous munitions areas.

6. Must be located $>1$ mile from commercial rail line.

Basis: Exclusion area means the area surrounding the reactor, in which the reactor licensee has the authority to determine all activities including exclusion or removal of personnel and property from the area. This area may be traversed by a highway, railroad, or waterway, provided these are not so close to the facility as to interfere with normal operations of the facility and provided appropriate and effective arrangements are made to control traffic on the highway, railroad, or waterway, in case of emergency, to protect the public health and safety. The primary concern is commercial rail lines.

7. Must be located outside wetland areas.

Basis: Protection of wetlands is mandated in Executive Order 11990. There is only one jurisdictional wetland defined at the INL Site, and it is in the vicinity of the Big Lost River Sinks. Given the high desert environment at INL, mitigation actions required to compensate for a location in a wetland would be difficult, leaving relocation of the facility as the most suitable option.

8. Must be located outside of Comprehensive Environmental Response, Compensation, and Liability Act (CERCLA) sites.

Basis: Siting a facility over or near a designated contamination area, including ordnances, was determined to be undesirable. Doing so could invoke costly remediation and monitoring requirements unrelated to the facility mission. It was determined the facility will not be sited over a known contamination area. 


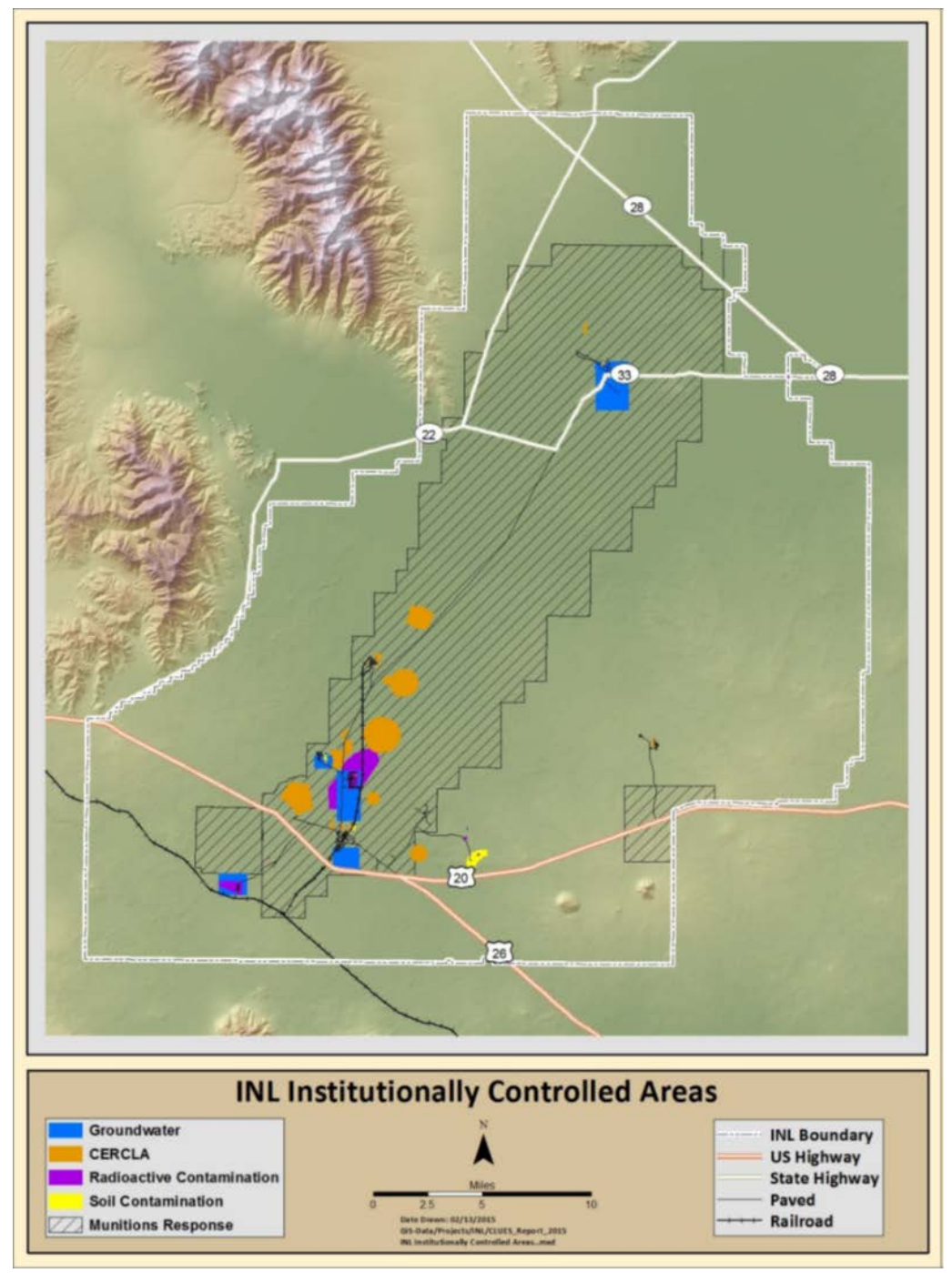

Figure 2. INL institutionally controlled areas.

9. Must be located outside of 100-year floodplain.

Basis: DOE G 420.1-2 stipulates that structures must not be in floodplains or in areas that are potentially subject to flooding due to dam failures to avoid consequences of NPHs (L.C. Kjelstrom and C. Berenbrock 1996).

10. Must meet minimum reactor design requirements.

Basis: Due to the pre-project phase of many of the anticipated advanced reactor designs that are anticipated to come to INL and the extensive list of alternate locations for siting these reactors, siting locations that do not meet minimum vendor expectations will not be evaluated during this siting study.

\section{2 "Want" Criteria Selection}

The NRC Regulatory Guide 4.7 was also used as the starting point in identifying applicable "Want" evaluation criteria. Below is the list of "Want" criteria and basis for criteria selection. 


\section{"Want” Criteria:}

1. Avoid areas of surface-water flooding/ponding.

Basis: A location with elevated topography and good surface-water drainage is required, while a location with subdued topography and poor surface-water drainage would be unacceptable, unless engineering controls were used to eliminate the potential for localized flooding or ponding.

2. Maximize proximity to suitable sources of cooling water.

Basis: The ideal location would minimize additional measures to provide for ready access to adequate amounts of cooling water.

3. Minimize disturbance of the critical habitat of protected species (i.e., sagebrush).

Basis: Selecting a siting area in a sagebrush-dominated location could result in a lengthy delay of design and construction. Stay out of sage grouse lek areas.

4. Avoid areas of high-predictive archaeology zones.

Basis: Based on many site-specific intensive surveys conducted in the past, there are numerous cultural resources (prehistoric and historic) identified on the INL Site, and a predictive analysis suggests there are many that have not been documented (DOE-ID 2016b). Locating the facility outside of high-predictive areas reduces the risk of uncovering archaeological material, thus reducing the risk to schedule variance and cost increases during the mitigation process.

5. Minimize potential adverse interactions with existing programs.

Basis: Considerations of this criterion include potential impact of displacing or impacting operations of collated or adjacent existing projects and programs. Consider impact to potential reprioritizing of existing programs and funding to do that. Potential No Go for some areas. Include impact of foreign national access.

6. Ensure appropriate security controls are available.

Basis: Design Basis Threats (DBTs) are based on quantities of special nuclear material (SNM); if the source material is being brought in then DOE DBT is negligible; if NRC power reactor requires full security system, then access controls might vary by customer; if the advanced small modular reactor is NRC licensed, this criteria might not be a delineator, but currently NRCimposed security requirements are unknown.

7. Minimize distance from transportation routes.

Basis: Locating the facility close to existing public transportation routes will reduce cost by minimizing new road construction and associated potential environmental and cultural resource impacts. Locating the facility near an existing transportation route, including main roads and rail lines, would provide easy delivery of construction materials and reduce construction costs by minimizing the need for potential new roads.

8. Minimize distance to transmission lines.

Basis: If connection to transmission lines are required for a advanced reactor design, the most favorable locations will be those collocated to the INL transmission loop. Figure 3 shows where INL transmission lines are located. 


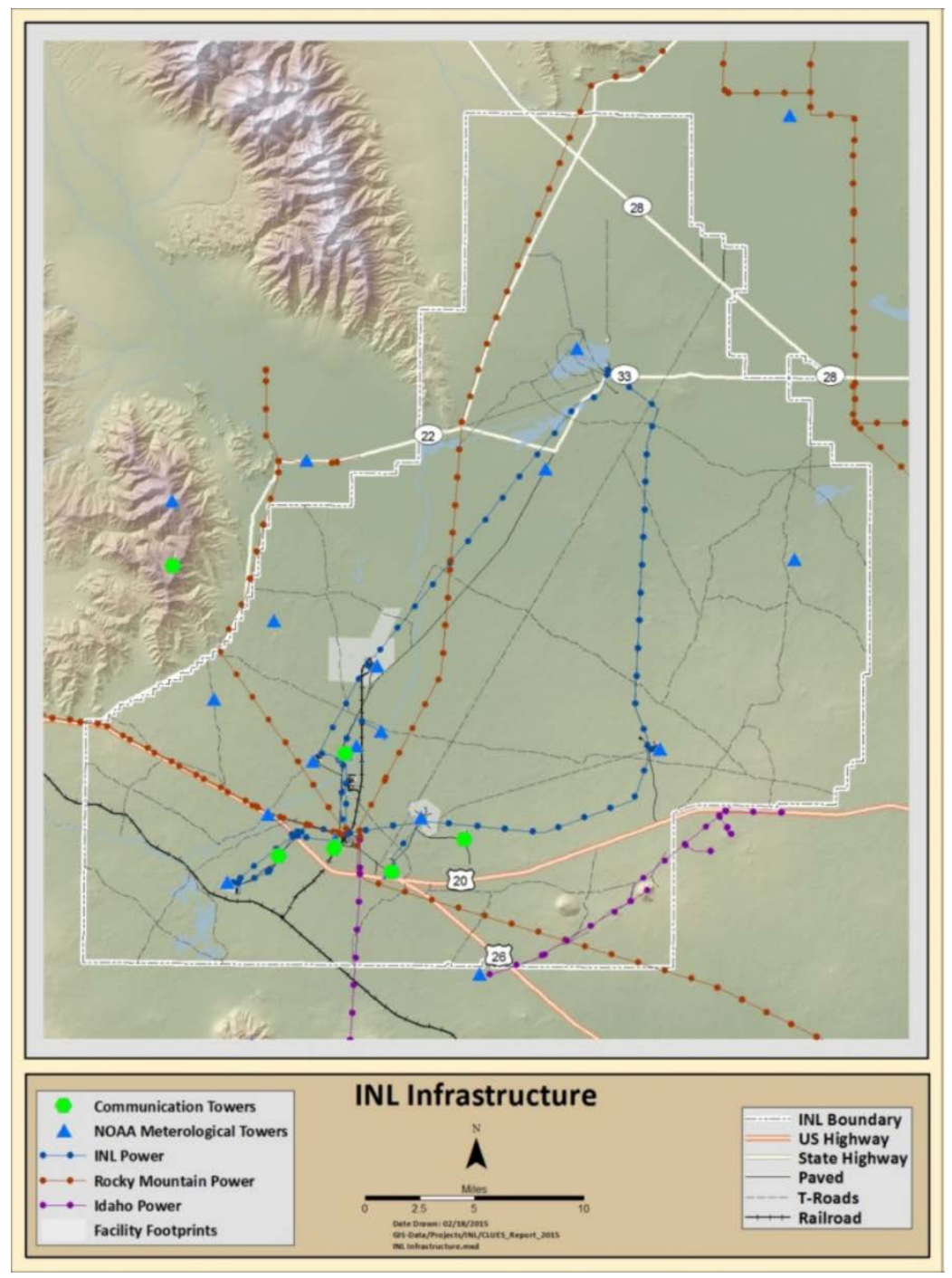

Figure 3. INL transmission lines.

9. Optimize use of Land Use planning zones.

Basis: Every three years, the INL Office of Campus Planning and Space Management works with a team of planning consultants and the laboratory community to update the Campus Master Plan (INL 2019b). The purpose of the Campus Master Plan is to provide a flexible framework for fulfilling physical needs as INL continues to grow and should be consulted during planning of new projects to ensure alignment with INL strategic goals.

10. Maximize use of updated seismic hazard analysis and site-specific characterization data.

Basis: As stated previously, INL recently completed a SSHAC Level 1 study (INL 2019a) at three INL sites (ATR, MFC, and NRF), which identified key seismic hazard issues and provided specific site-characterization data. The team chose to delineate and rank the sites based on this known data.

11. Minimize proximity to faults and building on soil sites.

Minimizing the risk from seismic events is an important consideration, as stated earlier. In addition to the "Must" criteria, the team chose to further delineate the sites based on proximity to 
the faults and those located on soils versus rock. Greater distances from faults and building on rock sites would result in lower motions; soil sites generally amplify ground motions by factors of 1.5 to 2 (Payne 2020).

\section{CANDIDATE SITES IDENTIFICATION}

This section identifies and provides a brief narrative description of each candidate site. A crosssection of locations at INL is included. The previously discussed study to site the CFPP on the INL Site (INL 2019c) was used to facilitate the identification of a large number of candidate advanced reactor sites as well as consulting the INL Campus Mater Plan (INL 2019b). A total of 32 candidate site locations were considered in this study, as shown in Figure 4.

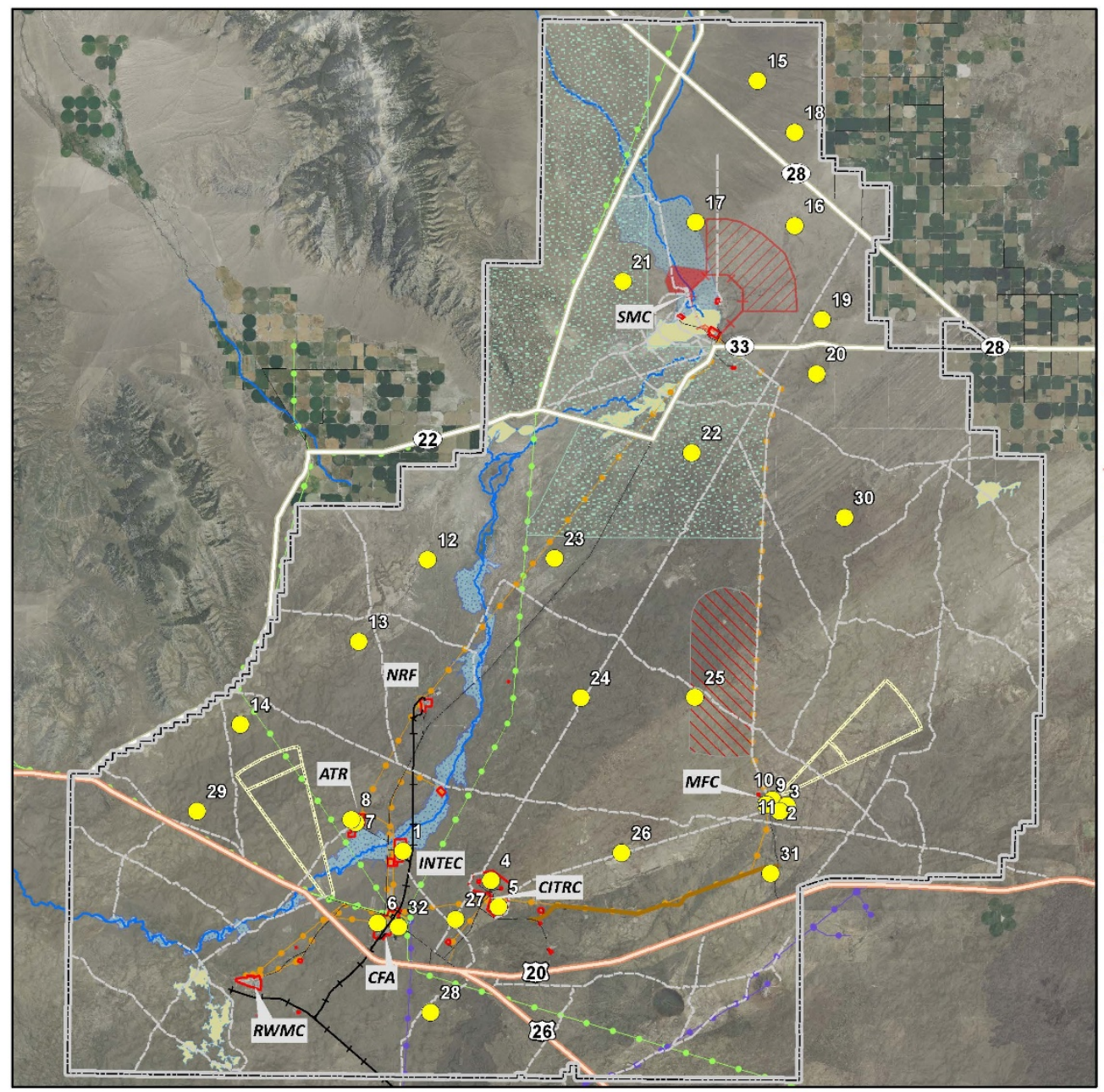

Advanced Reactor Siting Pre-evaluation Map

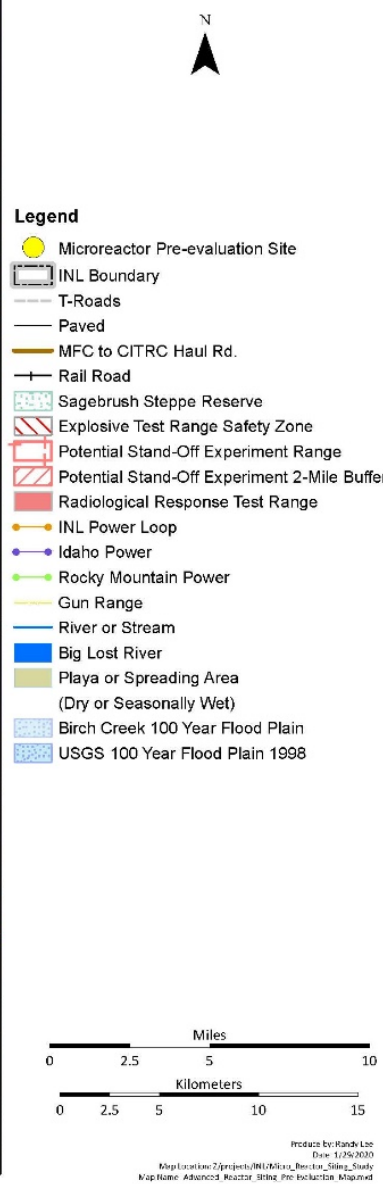

Figure 4. Candidate advanced reactor site locations.

Three types of site descriptors were evaluated: (1) Existing INL buildings; (2) Previously developed sites; and (3) Undeveloped sites. The basis for using these site descriptors is discussed in the following sections. 


\subsection{Existing INL Buildings}

Utilizing an existing INL building that is not fully utilized or is currently vacant includes advantages of prior analyses of most, if not all, site characteristics. If available, this information can greatly assist a advanced reactor site suitability evaluation and dramatically accelerate subsequent site assessments.

\subsubsection{CPP-691 Fuel Process Restoration (FPR) Project Facility (Location 1)}

This candidate building, CPP-691 (Figure 5), is a reinforced concrete building located at INTEC. It includes seven floors with four basement levels of shielded cells in an unfinished, largely unused building, with newly installed infrastructure support systems to make it operational.

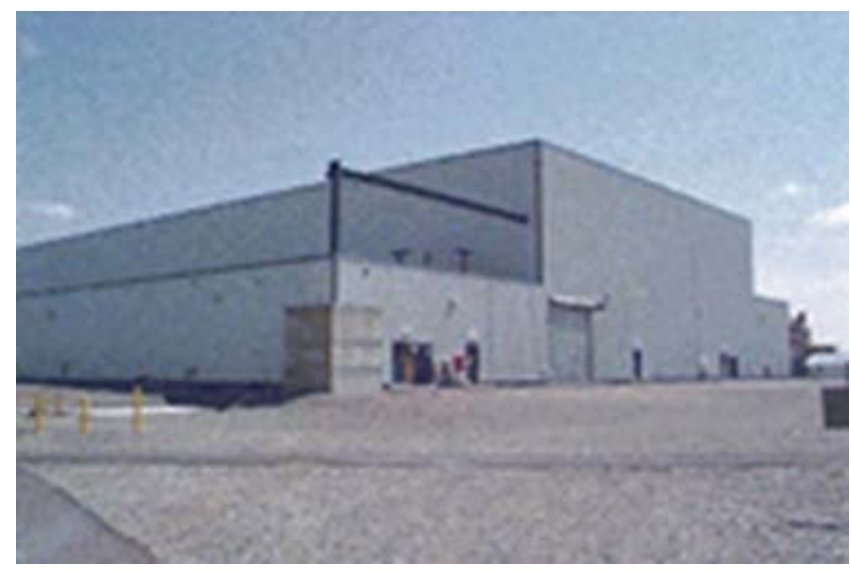

Figure 5. Candidate site \#1, CPP-691 (FPR).

The facility has an interior gross square footage of $172,953 \mathrm{ft}^{2}$ and contains 12 process cells. Seven cells are approximately $19 \times 34 \times 44$-ft. Two cells are about $19 \times 36 \times 44$-ft. Cell \#10 is $16 \times 14 \times 44$-ft, and cell \#11 is about $23 \times 16 \times 13$-ft. Cell \#12 is $22 \times 16 \times 27$-ft. Some of the cells have stainless steel lining already installed on them. There were two sampler cells of $32 \times 7 \times 12$-ft that were part of the original design. They are located to the south of the process cells on the second level.

It includes a 50-ton overhead crane with overhead crane rail and PaR Systems Corporation (PaR) rail in the high bay maintenance area for access to the cells. Access to the high bay maintenance area includes an overhead rollup door of $10 \times 15-\mathrm{ft}$.

There is an existing partial paved, partial gravel road to CPP-691. There are also INL railroad tracks adjacent to the building to the east. There is adequate space for a truck to pull into and out of the area. CPP-691 currently resides outside the INTEC perimeter security fence.

\subsubsection{MFC-767 (EBR-II) Plant Building (Location 2)}

This candidate building, MFC-767 (Figure 6), formally housed the Experimental Breeder Reactor II (EBR-II). Since the EBR-II was decommissioned, the capability for the dome to provide qualified containment has ended.

MFC-767 is a cylindrical structure with a hemispherical dome and an ellipsoidal bottom surface. The cylindrical portion has an inside shell diameter of $80 \mathrm{ft}$. The structure projects $95 \mathrm{ft} 3 \mathrm{in}$. above grade and $43 \mathrm{ft} 6$ in. below grade. The structure includes an operating floor and several below grade levels, along with a reactor cavity. The structure includes several openings near existing grade for access and penetrations. Near the top of the cylinder is a reinforced concrete corbel that supports a crane rail and polar crane.

Upgrades to the structure that were completed in December 2019 include: 
- Repair of the dome access structure

- Updates to the dome floor to support a reactor and avoid disturbing contamination below the structure

- Reestablishment of the engineering safety features related to containment

- Reestablishment of access to utilities.

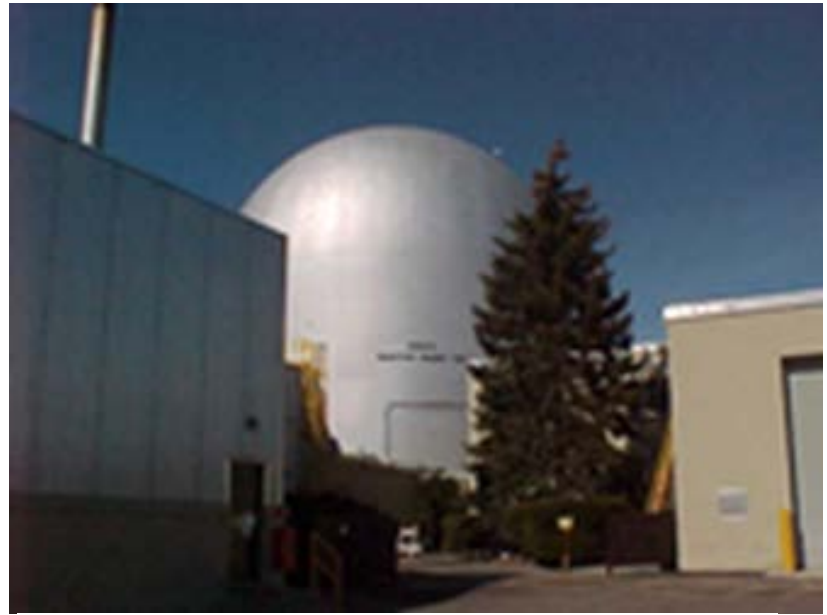

Figure 6. Candidate site \#8, MFC-767 (EBR-II).

\subsubsection{MFC-775 and MFC-776 (ZPPR) Reactor Buildings (Location 3)}

The Zero Power Physics Reactor (ZPPR) was a reactor facility that contained both hazard category 2 and 3 areas. It was originally used to categorize core dynamics of nuclear materials. The reactor was decommissioned and removed in 2009. The workroom, vault, and inside equipment rooms are part of the earth covered mound. Access is normally controlled through Security Post 209. Nuclear material, consisting of reactor fuel sources, heat sources, and miscellaneous items such as foils and counters, is currently stored in the vault (INL 2014).

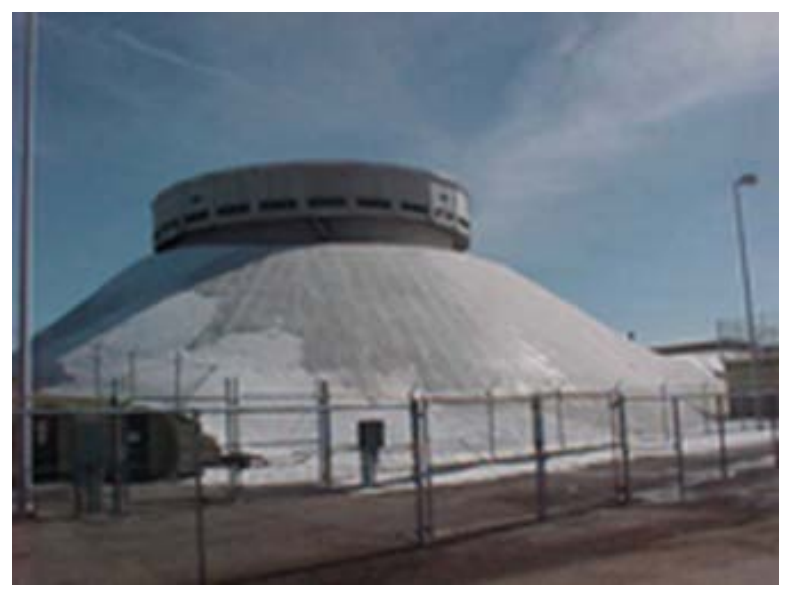

Figure 7. Candidate site \#3, MFC-775/776 (ZPPR). 


\subsubsection{PBF-612 (CITRC) Control System Research Facility (Location 4)}

The Power Burst Facility (PBF) entered operation in 1972 to support DOE and NRC in studying nuclear reactor fuel as a part of the Special Power Excursion Reactor Tests (SPERT) program. The four SPERT reactors were initially constructed for safety studies and irradiation testing of light-water reactors. The remaining buildings, PBF-612 and PBF-613, now support the CITRC and offer opportunity for separation or mobile reactor test stands if needed for reactor development. This area is well supported with water and electrical power, located adjacent to the Antelope Substation, and has independent access to both Highway 20 and INL operations areas.

PBF-612 is a $60 \times 90$-ft building with a $40 \times 90$-ft bay area on the first floor with a varying floor capacity of $100-200 \mathrm{lb} / \mathrm{ft}^{2}$. The basement is roughly $44 \times 37 \times 22-\mathrm{ft}$. The floor plan in the basement is broken up by steel platforms at multiple levels. There are two $10 \times 10$-ft bay doors on opposite sides of the building, and an overhead crane which can be used to bring equipment into the building. There are plenty of open asphalt staging areas around the building. PBF-612 provides restrooms, a breakroom, a conference room, and office space to accommodate 10-15 personnel.

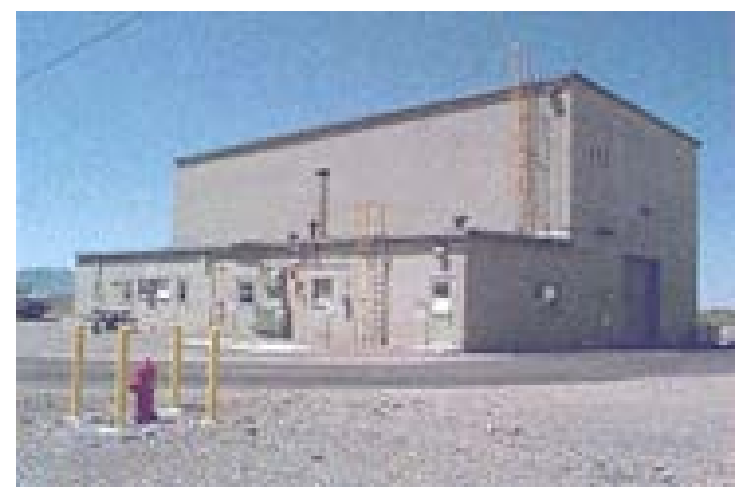

Figure 8. Candidate site \#4, PBF-612.

\subsubsection{PBF-613 (CITRC) Communications Research Facility (Location 5)}

PBF-613 is also being considered for utilization in the demonstration of advanced reactors. It is a 60 $\times 90$-ft building with a $40 \times 90$-ft bay area on the first floor with a floor loading capacity of $750 \mathrm{lb} / \mathrm{ft}^{2}$. The basement is roughly $44 \times 37 \times 22$-ft. It is a unique building in that it has high ceilings and an operational overhead 10 -ton crane.

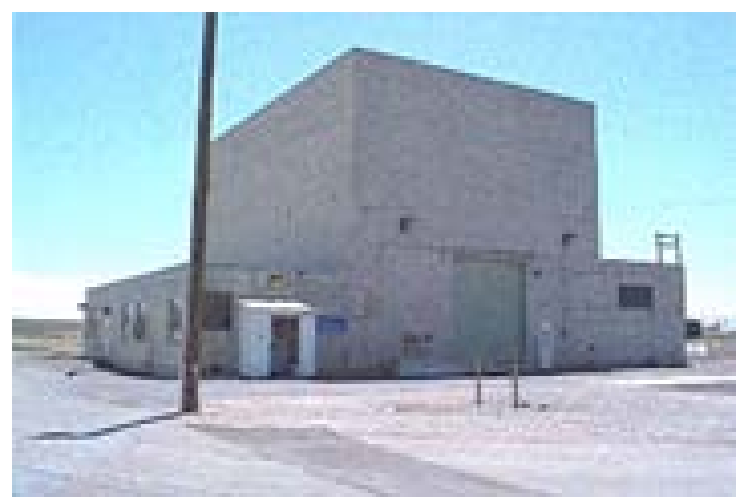

Figure 9. Candidate site \#5, PBF-613. 


\subsection{Previously Developed Sites}

Previously developed siting options are defined in this report as land areas that have been previously disturbed or developed that are not currently in use. These areas pose a lower risk of uncovering unidentified cultural artifacts and have easy access to existing INL infrastructure.

\subsubsection{Near CFA (Locations 6 and 32)}

CFA is about three miles from the intersection of Highway 20 and 26, through the main security gate, or three miles from Highway 20 through the west side security gate. There are multiple previously developed sites at CFA that could be used by advanced reactor developers (see Figure 10). These sites are close to INL operations and emergency services.

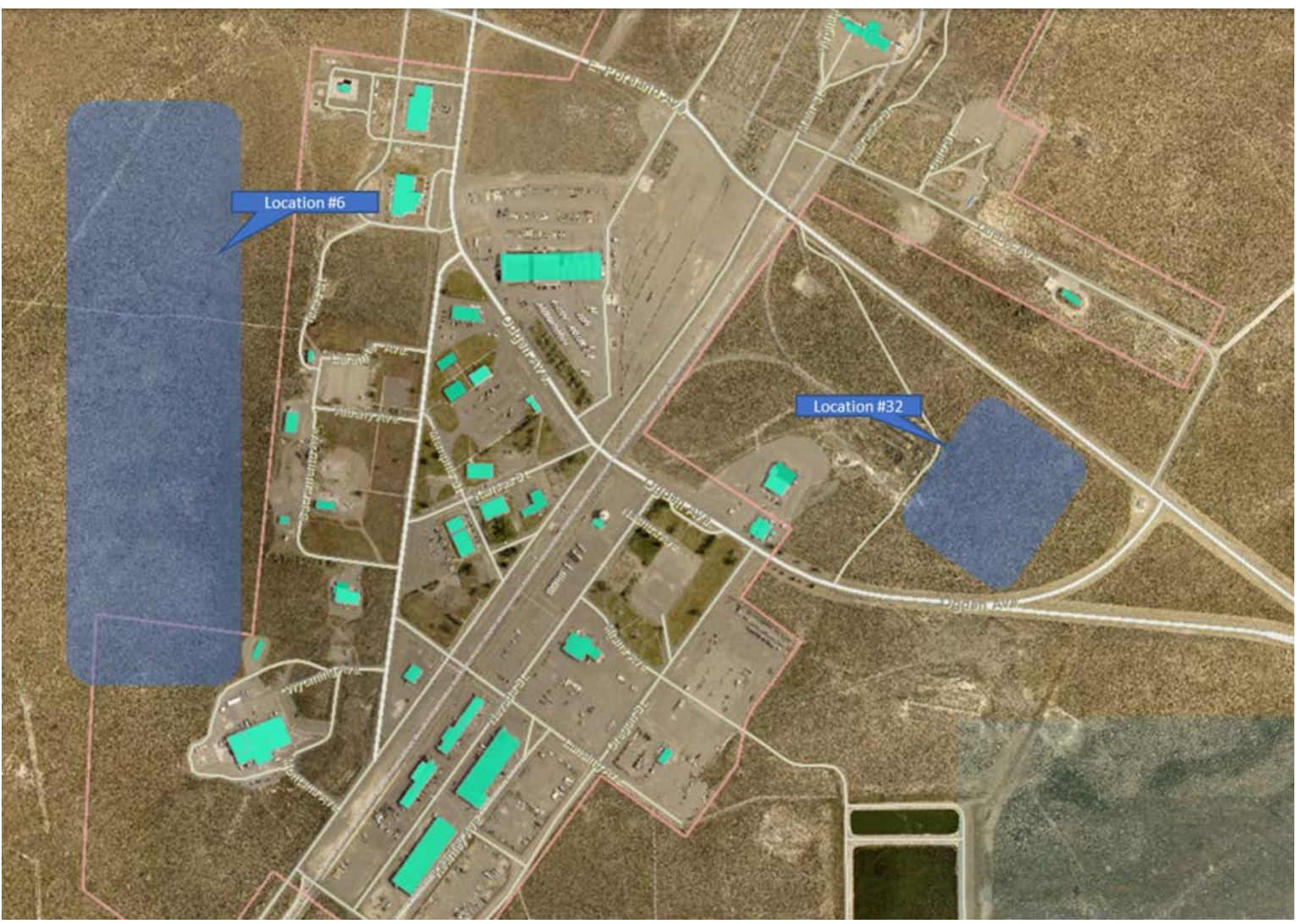

Figure 10. Proposed previously developed sites near CFA.

Roads in and around the area exist, including access to Haul Road. Haul Road is not a common use road at this time and will be barricaded at the MFC and CITRC ends to control use for safety, shipment, security, and maintenance concerns. There are potential limitations on using the road, such as weather conditions, conflicts with use by other programs, load limitations, etc. Also, per EC INL-18-045, "Environmental Checklist for the Haul Road," the road has a design capacity for a 100,000-lb gross vehicle weight, double-droop, three-axle trailer with a 6-inch ground clearance. Shipments not exceeding 80,000 lb can occur from 2010 to 2050. In addition, a DOE-owned railroad track also passes north at Scoville Siding from Mackay Branch through CFA, past the east side of INTEC, and terminates within NRF. A spur line runs west to connect this track through the south end of the INTEC Fuel Storage Facility to the coal-fired plant. A portion of this line is presently out of service. Locating advanced reactor development could introduce a level of complexity with collocated INL workers regarding emergency planning and evacuation routes if needed. 


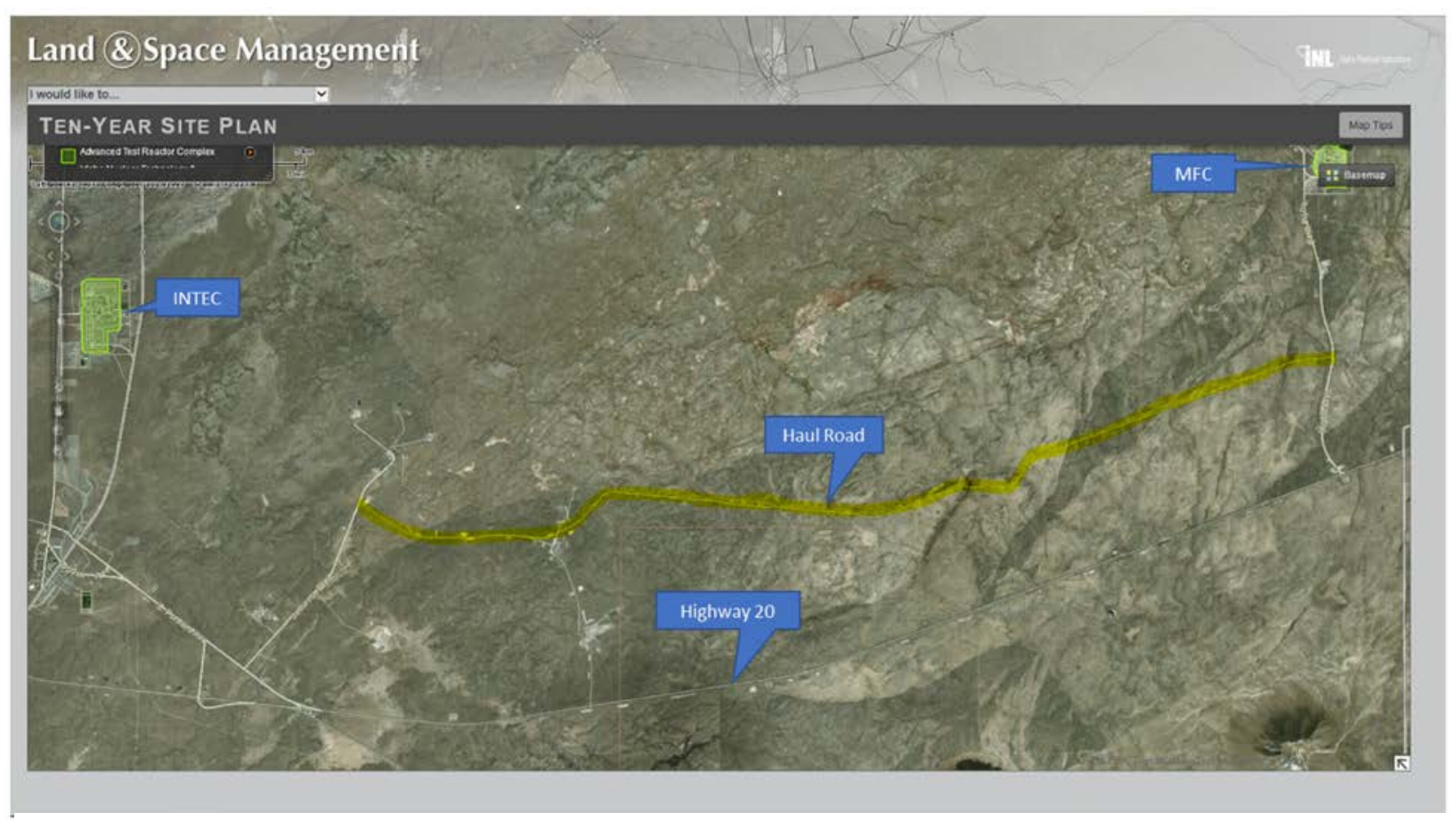

Figure 11. Haul Road location.

\subsubsection{Inside the ATR Complex (Location 7)}

The ATR Complex houses ATR, one of the world's most versatile materials test reactor. A lowtemperature, pressurized, water-cooled reactor for steady-state irradiation, ATR is fully subscribed, meeting the needs of DOE-NE, Naval Reactors, the National Nuclear Security Administration, and many other research users. Other facilities in the ATR Complex include the associated ATR Critical Facility, a Test Train Assembly Facility, and a supporting radioanalytical laboratory that began operation in 2010.

The ATR Complex historically has supported fuel development for the Navy's nuclear propulsion program. Over the last decade, its use has expanded into other mission areas that include particle fuel development for the high-temperature gas reactor, minor actinide-bearing fuel development, and lowenriched fuel for the National Nuclear Security Administration's Reduced Enrichment for Research and Test Reactor Program, which is part of the Global Threat Reduction Initiative. In addition, ATR is one of two test reactors designated by a DOE record of decision as suitable for future production of Pu-238 (INL 2016b).

The ATR Complex, located at the center of the INL Site, is about six miles from Highway 20. ATR operations could contribute to access and planning complexity. Reactors that would benefit from operational support from an actively operating reactor complex could benefit from being near ATR. The site is well characterized and has the infrastructure to support a new nuclear reactor. A recent upgrade to the utility corridor at the ATR Complex may provide cost effective access to future, project-specific utility requirements. Figure 12 illustrates the candidate previously developed site within the ATR Complex. 


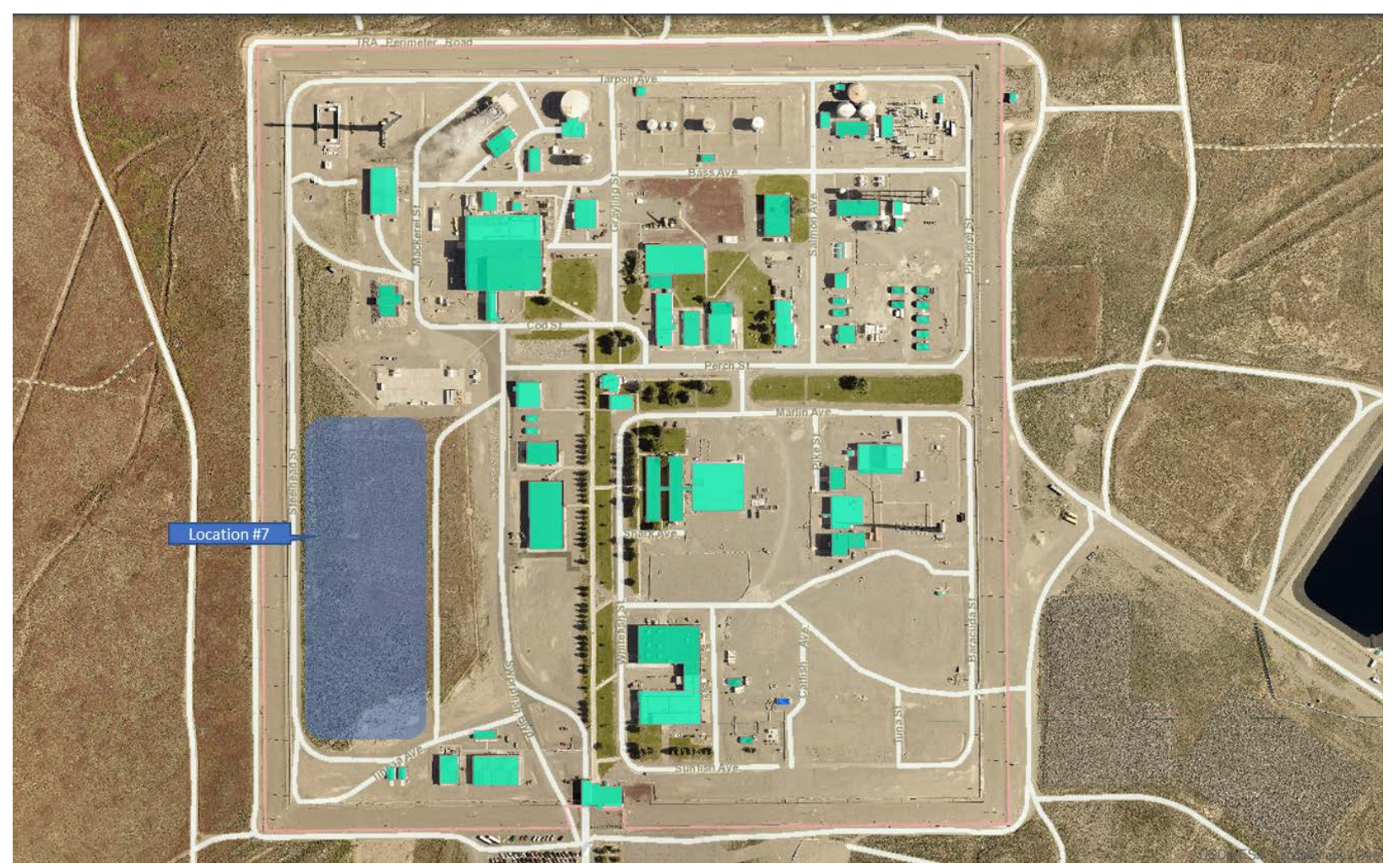

Figure 12. Proposed previously developed site inside the ATR Complex.

\subsection{Undeveloped Sites}

The undeveloped siting options, as used in this study, are areas that have not been previously disturbed or developed. There are multiple locations on the INL Site that could be used to build a reactor. These sites can be integral with or provide separation from INL operations. There are sites all along the boundary of the INL Site that could be developed to provide independent access depending on project need.

Development of an undeveloped site can be undertaken with relatively little concern about prior activities. However, there may be relatively little site-specific data available to support a thorough initial site suitability evaluation. Determining whether an undeveloped site is a viable advanced reactor location may involve greater levels of uncertainty due to risks posed to pristine environments and protected indigenous species.

Due to the large number of undeveloped sites included in this study, the criterion-by-criterion descriptions are presented in detail in Appendix A of this siting study. 


\subsubsection{Near the ATR Complex (Location 8)}

As discussed in the INL Campus Master Plan, a portion of the future research-focused development is planned to occur on the western portion of the complex, outside of the secure area. Figure 13 illustrates the proposed undeveloped site on the west side of the ATR Complex.

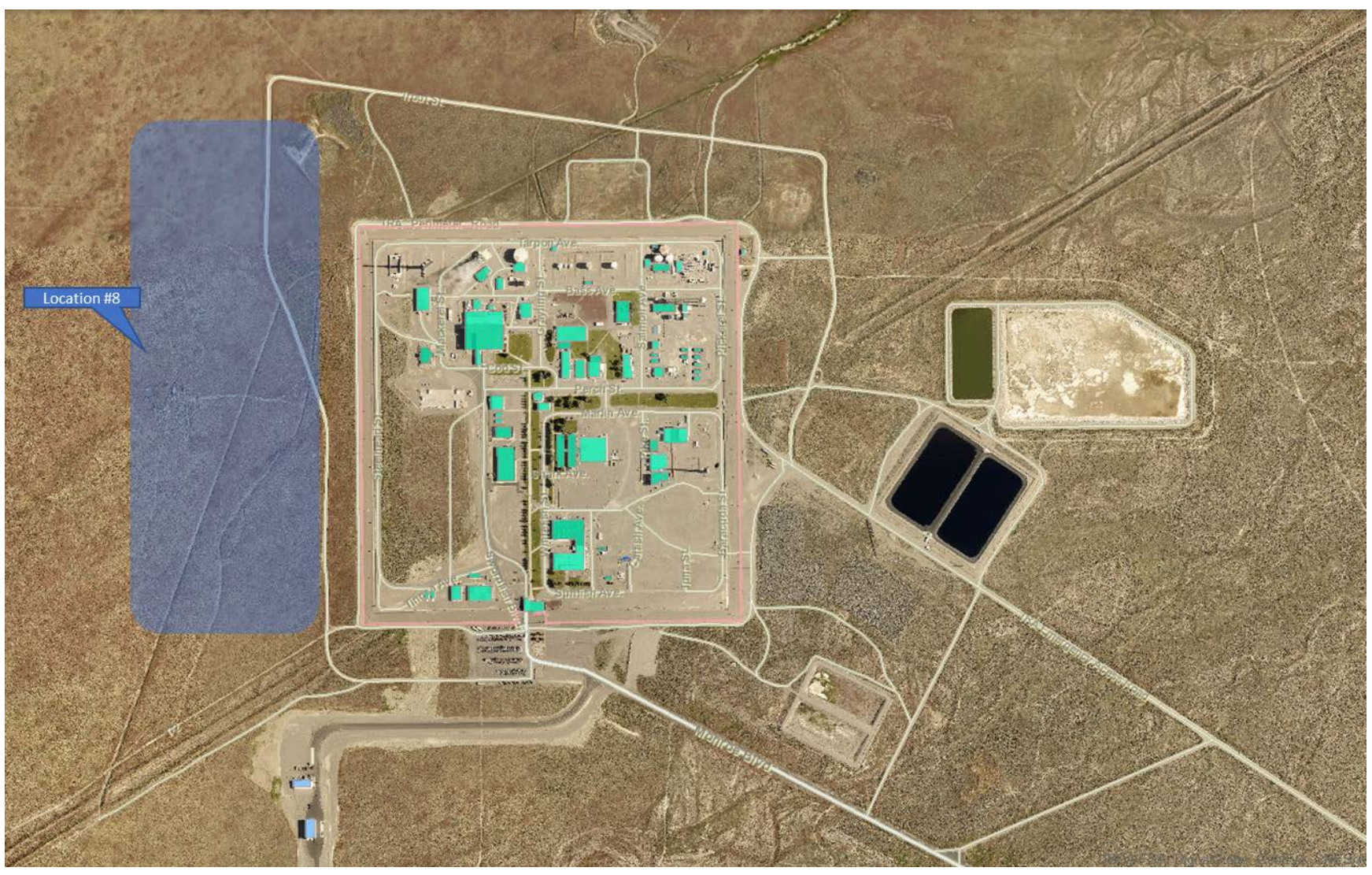

Figure 13. Proposed undeveloped site adjacent to the ATR Complex.

\subsubsection{Near MFC (Locations 9-11)}

MFC is located 28 miles west of Idaho Falls and houses one-of-a-kind hot cell capabilities within the Hot Fuel Examination Facility and the Fuel Conditioning Facility for conducting world-class nuclear research. Additional hot cell capabilities reside in the Analytical Laboratory and the Fuels and Applied Science Building. The recent addition of the Irradiated Materials Characterization Laboratory and ongoing installation of research equipment addresses a previously identified capability gap and allows for preparation of fuel samples for testing.

Facilities at MFC also include analytical laboratories (including mass separators), the Electron Microscopy Laboratory for isotopic and nanometer-scale microstructural and microchemical analysis of material samples from its research facilities, and collocated fuel fabrication glovebox lines (e.g., Fuel Manufacturing Facility and Fuels and Applied Science Building). In addition, MFC operates the Space and Security Power Systems Facility for final assembly and testing of radioisotope power systems and provides capabilities supporting National and Homeland Security R\&D.

Significant infrastructure investment has occurred and will continue to occur at MFC. Resumption of transient testing restarted in Fiscal Y 2018 at the Transient Reactor Test Facility (INL 2016a). 
The area around MFC is not in the floodplain of the Big Lost River, but the west side of MFC, just outside the fence, is subject to flooding due to snowmelt and rainstorms (Irving 2019).

In 2010, BEA contracted Portage, Inc. to perform a diversion dam inspection to assess the ability of the dam to operate as originally designed. As documented in TEV-1368, "MFC Flood Control Diversion Dam Evaluation," the evaluation found, based on the existing ground model, the flood pathway adequate to divert water from the MFC site. However, it appears the pathway will not be able to divert a large storm event. The recommendation from this 2010 analysis was to construct conveyance ditches in two areas with no defined channel to ensure flood water is properly conveyed from the diversion dam without excessively flooding areas surrounding the MFC site. Figure 14 shows the proposed candidate undeveloped site locations around MFC, as well as the candidate existing building locations.

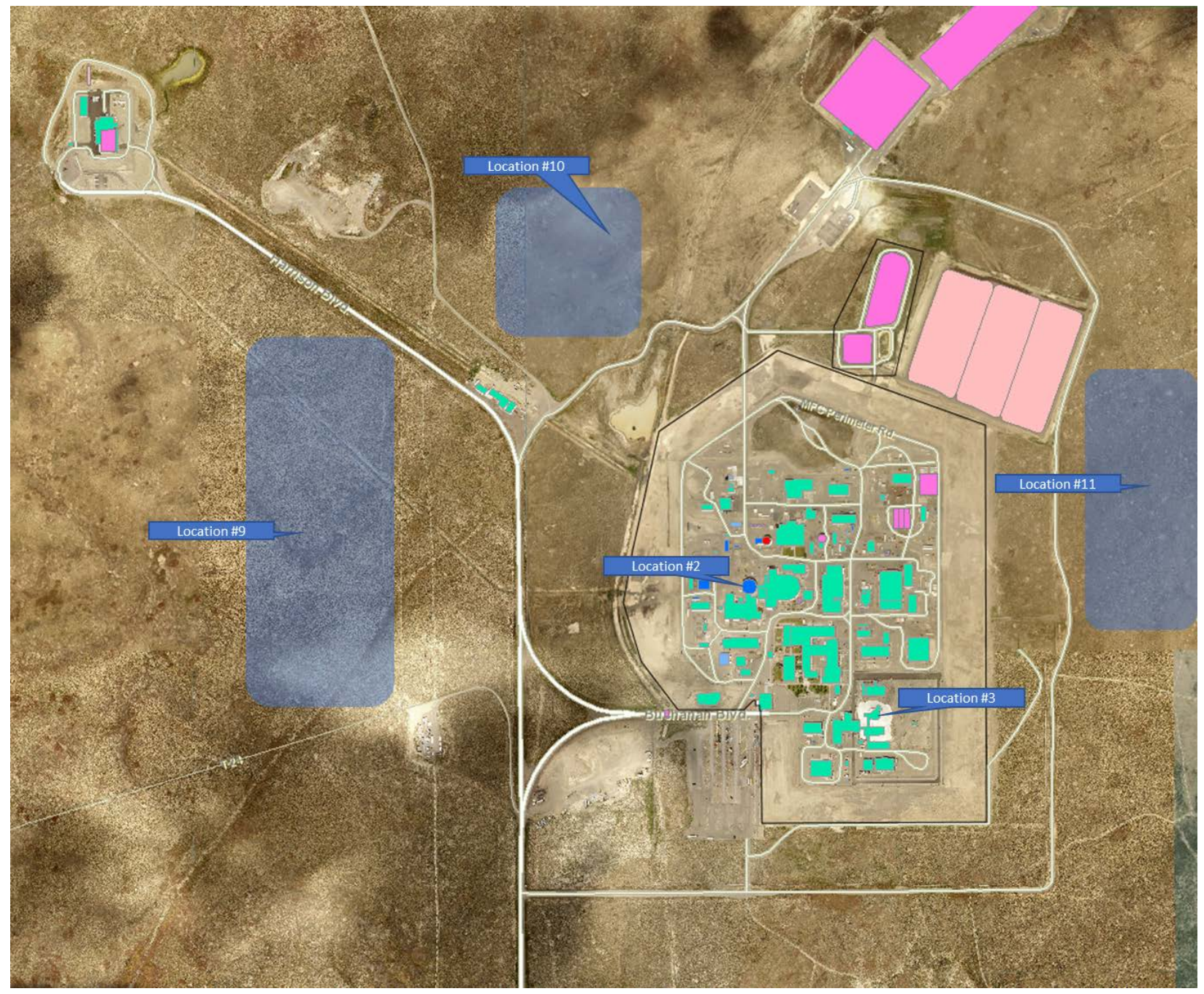

Figure 14. Proposed undeveloped sites around MFC (siting locations \#9, \#10, and \#11) in reference to proposed existing building sites (siting locations \#2 and \#3). 


\section{4. "MUST" CRITERIA SCREENING}

The third step in the evaluation process requires each of the candidate sites be evaluated against the "Must" criteria. Nine of the 32 sites failed the siting study "Must" criteria evaluation (as shown in

Table 2). The nine that failed are highlighted in gray.

Table 2. "Must" criteria evaluation.

\begin{tabular}{|c|c|c|c|c|c|c|c|c|c|c|}
\hline \multirow[b]{2}{*}{ Site } & \multicolumn{10}{|c|}{$\begin{array}{c}\text { Criteria } \\
(\mathbf{P}=\text { Pass, } \mathrm{F}=\text { Fail })\end{array}$} \\
\hline & $\begin{array}{l}\text { Must be } \\
\text { located } \\
>10 \\
\text { miles } \\
\text { from an } \\
\text { airport }\end{array}$ & $\begin{array}{c}\text { Must be in } \\
\text { an area of } \\
<0.5 \mathrm{G} \text { Peak } \\
\text { Ground } \\
\text { Acceleration }\end{array}$ & $\begin{array}{l}\text { Must be } \\
\text { located }>5 \\
\text { miles from } \\
\text { surface } \\
\text { faults and } \\
\text { capable } \\
\text { tectonic } \\
\text { structures }\end{array}$ & $\begin{array}{c}\text { Must be } \\
\text { located } \\
\text { away from } \\
\text { population } \\
\text { centers of } \\
>25,000 \\
\text { people }\end{array}$ & $\begin{array}{l}\text { Must be } \\
\text { located }>5 \\
\text { miles } \\
\text { from } \\
\text { hazardous } \\
\text { site }\end{array}$ & $\begin{array}{l}\text { Must be } \\
\text { located }>1 \\
\text { mile from } \\
\text { commercial } \\
\text { rail line }\end{array}$ & $\begin{array}{l}\text { Must be } \\
\text { located } \\
\text { outside } \\
\text { wetland } \\
\text { areas }\end{array}$ & $\begin{array}{l}\text { Must be } \\
\text { located } \\
\text { outside } \\
\text { of } \\
\text { CERCLA } \\
\text { sites }\end{array}$ & $\begin{array}{l}\text { Must be } \\
\text { located } \\
\text { outside of } \\
100 \text {-year } \\
\text { floodplain }\end{array}$ & $\begin{array}{c}\text { Must meet } \\
\text { minimum } \\
\text { reactor design } \\
\text { requirements }\end{array}$ \\
\hline 1 & $P$ & $P$ & $P$ & $P$ & $P$ & $P$ & $P$ & $P$ & $P$ & $P$ \\
\hline 2 & $P$ & $P$ & $P$ & $P$ & $P$ & $P$ & $P$ & $P$ & $P$ & $P$ \\
\hline 3 & $P$ & $P$ & $P$ & $P$ & $P$ & $P$ & $P$ & $P$ & $P$ & $P$ \\
\hline 4 & $P$ & $P$ & $P$ & $P$ & $P$ & $P$ & $P$ & $P$ & $P$ & $\mathbf{F}$ \\
\hline 5 & $P$ & $P$ & $P$ & $P$ & $P$ & $P$ & $P$ & $P$ & $P$ & $P$ \\
\hline 6 & $P$ & $P$ & $P$ & $P$ & $P$ & $P$ & $P$ & $P$ & $P$ & $P$ \\
\hline 7 & $P$ & $P$ & $P$ & $P$ & $F$ & $P$ & $P$ & $P$ & $P$ & $P$ \\
\hline 8 & $P$ & $\mathrm{P}$ & $P$ & $P$ & $\mathrm{P}$ & $P$ & $P$ & $P$ & $\mathrm{P}$ & $P$ \\
\hline 9 & $P$ & $P$ & $P$ & $P$ & $P$ & $P$ & $P$ & $P$ & $P$ & $P$ \\
\hline 10 & $P$ & $P$ & $P$ & $P$ & $P$ & $P$ & $P$ & $P$ & $P$ & $P$ \\
\hline 11 & $P$ & $P$ & $P$ & $P$ & $P$ & $P$ & $P$ & $P$ & $P$ & $P$ \\
\hline 12 & $P$ & $P$ & $P$ & $P$ & $P$ & $P$ & $P$ & $P$ & $P$ & $P$ \\
\hline 13 & $P$ & $P$ & $P$ & $P$ & $P$ & $P$ & $P$ & $P$ & $P$ & $P$ \\
\hline 14 & $P$ & $P$ & $P$ & $P$ & $F$ & $P$ & $P$ & $P$ & $P$ & $P$ \\
\hline 15 & $P$ & $P$ & $P$ & $P$ & $P$ & $P$ & $P$ & $P$ & $P$ & $P$ \\
\hline 16 & $P$ & $\mathrm{P}$ & $\mathrm{P}$ & $\mathrm{P}$ & $\mathrm{P}$ & $P$ & $P$ & $P$ & $\mathrm{P}$ & $P$ \\
\hline 17 & $P$ & $P$ & $P$ & $P$ & $\mathrm{P}$ & $P$ & $P$ & $P$ & $\mathbf{F}$ & $P$ \\
\hline 18 & $P$ & $P$ & $P$ & $P$ & $P$ & $P$ & $P$ & $P$ & $P$ & $P$ \\
\hline 19 & $P$ & $P$ & $P$ & $P$ & $P$ & $P$ & $P$ & $P$ & $P$ & $P$ \\
\hline 20 & $\mathrm{P}$ & $\mathrm{P}$ & $\mathrm{P}$ & $\mathrm{P}$ & $\mathbf{F}$ & $\mathrm{P}$ & $\mathrm{P}$ & $\mathrm{P}$ & $\mathrm{P}$ & $\mathrm{P}$ \\
\hline 21 & $P$ & $P$ & $P$ & $P$ & $P$ & $P$ & $P$ & $P$ & $P$ & $P$ \\
\hline 22 & $P$ & $P$ & $P$ & $P$ & $\mathbf{F}$ & $P$ & $P$ & $P$ & $P$ & $P$ \\
\hline 23 & $P$ & $P$ & $P$ & $P$ & $\mathbf{F}$ & $P$ & $P$ & $P$ & $P$ & $P$ \\
\hline 24 & $P$ & $\mathrm{P}$ & $\mathrm{P}$ & $\mathrm{P}$ & $\mathbf{F}$ & $P$ & $\mathrm{P}$ & $P$ & $\mathrm{P}$ & $P$ \\
\hline 25 & $\mathrm{P}$ & $\mathrm{P}$ & $\mathrm{P}$ & $\mathrm{P}$ & $P$ & $\mathrm{P}$ & $\mathrm{P}$ & $\mathrm{P}$ & $\mathrm{P}$ & $\mathrm{P}$ \\
\hline 26 & $P$ & $\mathrm{P}$ & $\mathrm{P}$ & $P$ & $\mathrm{P}$ & $P$ & $\mathrm{P}$ & $P$ & $\mathrm{P}$ & $P$ \\
\hline 27 & $P$ & $P$ & $P$ & $P$ & $\mathbf{F}$ & $P$ & $P$ & $P$ & $P$ & $P$ \\
\hline 28 & $P$ & $P$ & $P$ & $P$ & $P$ & $P$ & $P$ & $P$ & $P$ & $P$ \\
\hline 29 & $\mathrm{P}$ & $\mathrm{P}$ & $\mathrm{P}$ & $\mathrm{P}$ & $\mathrm{P}$ & $P$ & $P$ & $P$ & $\mathrm{P}$ & $P$ \\
\hline 31 & $P$ & $P$ & $P$ & $P$ & $P$ & $P$ & $P$ & $P$ & $P$ & $P$ \\
\hline 31 & $P$ & $P$ & $P$ & $P$ & $P$ & $P$ & $P$ & $P$ & $P$ & $P$ \\
\hline 32 & $P$ & $P$ & $P$ & $P$ & $P$ & $P$ & $P$ & $P$ & $P$ & $P$ \\
\hline
\end{tabular}

Of the nine sites that failed the "Must" criteria evaluation, seven failed the "Must be located $>5$ miles from hazardous site" criterion.

Candidate site location \#4, PBF-612 - CITRC Control System Research Facility, failed the "Must meet minimum reactor design requirements" criterion. A key assumption for the potential use of an existing building is that the building must have a minimum floor loading capacity of $750 \mathrm{lb} / \mathrm{ft}^{2}$ to enable 
forklift movements within the building. The ground level floor of PBF-612 currently has a floor load capacity that ranges from $100-200 \mathrm{lb} / \mathrm{ft}^{2}$.

Candidate site location \#17 failed due to being located within the 100-year Birch Creek floodplain (L.C. Kjelstrom and C. Berenbrock 1996).

The sites that remain for further evaluation are illustrated in Figure 15.

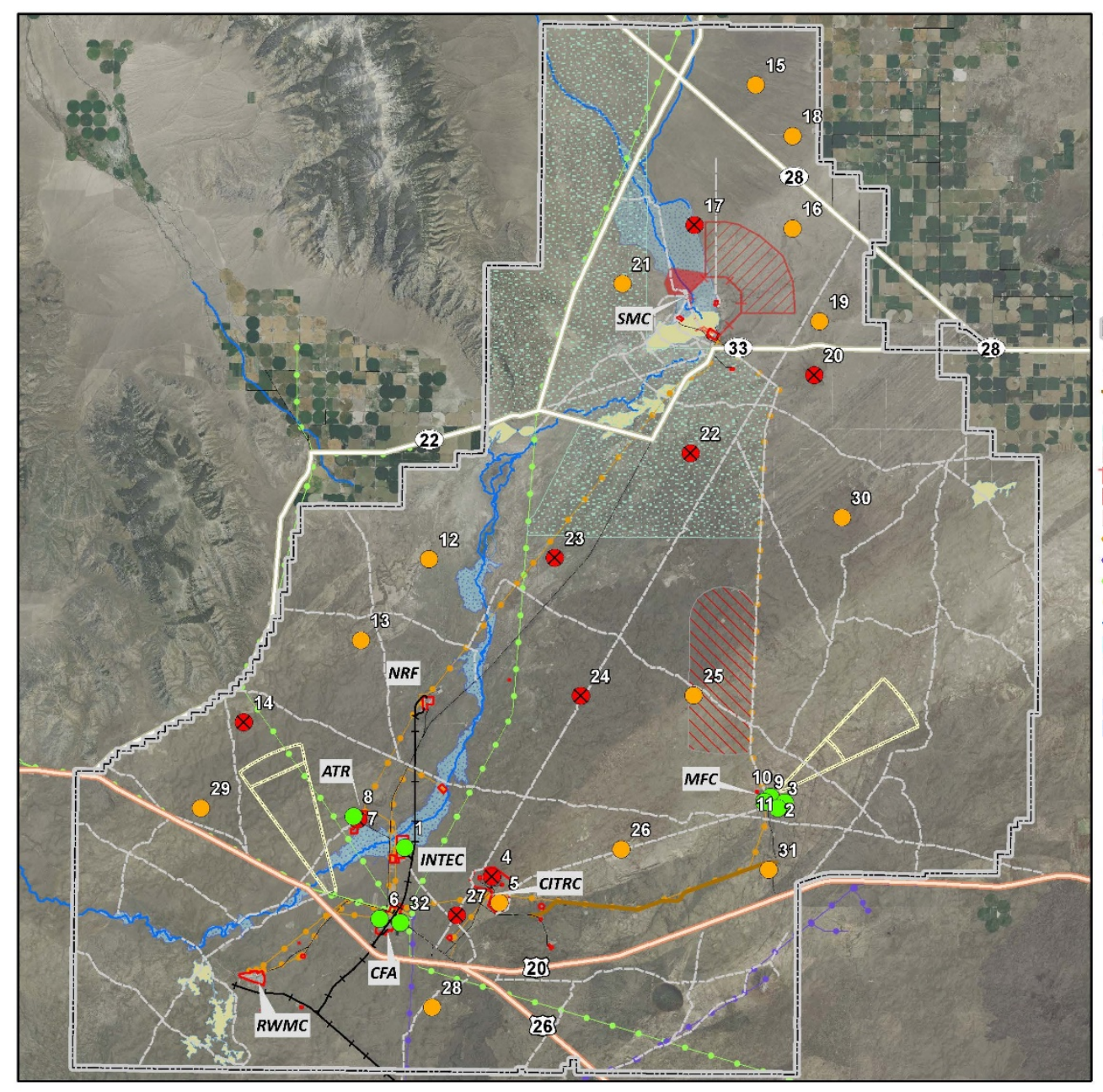

Advanced Reactor Siting Evaluation Map

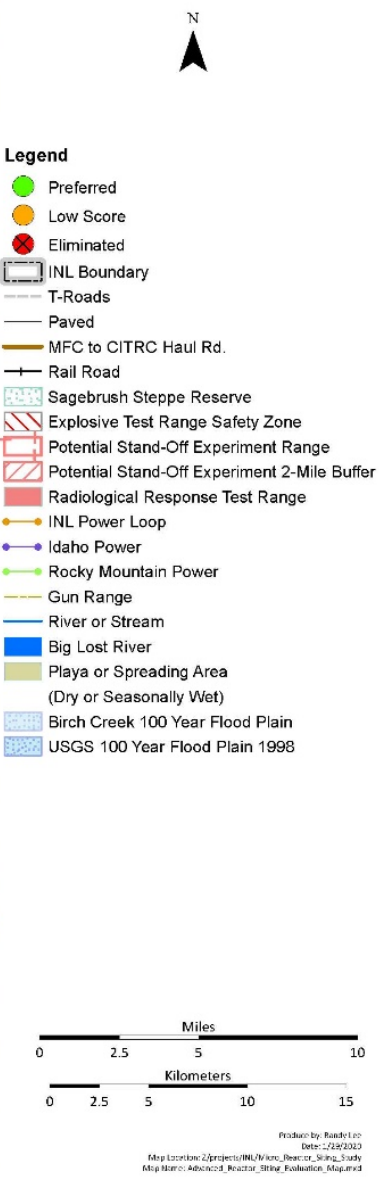

Figure 15. Remaining candidate advanced reactor sites.

\section{ALTERNATIVE EVALUATION}

The alternative evaluation was conducted as a facilitated decision analysis meeting and included a cross-functional team of 19 technical representatives. During the evaluation, which was initiated on January 15, 2020 and concluded on January 23, 2020, facilitated discussions were held and decisions made that were acceptable to the meeting participants. The following subsections summarize the outcomes of the evaluation process. See Appendix B for the agendas and roster of meeting participants.

\subsection{Criteria Ranking}

Using a paired comparison method, the "Want" criteria were ranked against each other in order to weight the criteria based on importance. Using this method, each criterion was compared with the other 
criteria. Meeting participants decided which criterion was more important and assigned a weighting factor on a scale of 5-0 to signify how much more important one criterion was over another.

The results of this comparison provided weighting factors for each of the "Want" criteria. Table 3 displays the results and 5-0 scale definitions of the paired comparison.

Table 3. Paired comparison results of "Want" criteria.

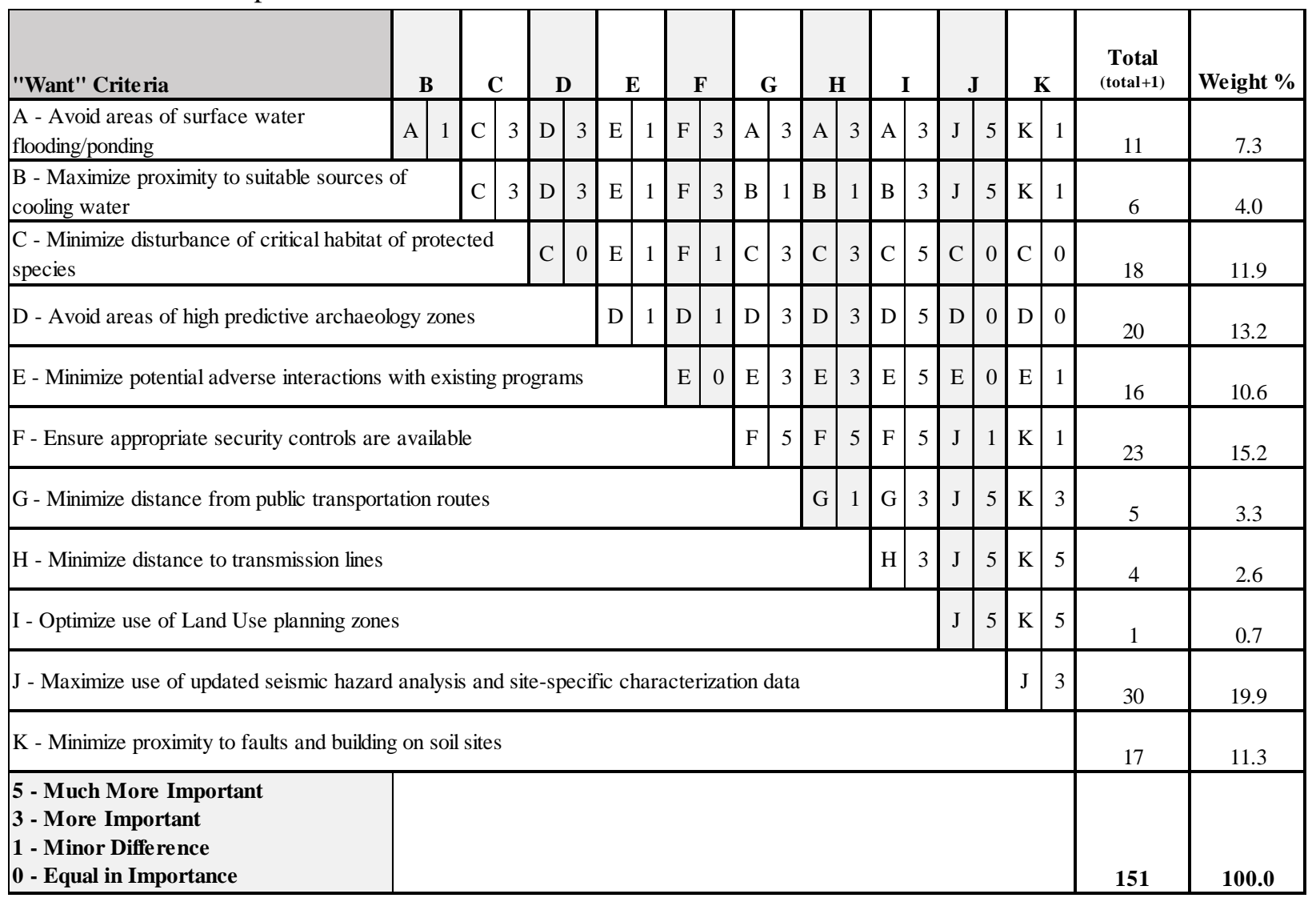

\subsection{Candidate Sites Evaluation}

The next step was to use the weighted "Want" criteria to evaluate candidate site locations. This was done by assigning a value of $10-0$ to a candidate site based on how well the site scored against each criterion. The $10-0$ scale is defined as follows:

- Scoring Definitions for A to I and K:

$10=$ Candidate site meets criterion with minimal to no difficulty

5 = Candidate site meets criterion with some difficulty

$1=$ High degree of uncertainty as to whether the candidate site can meet criterion

$0=$ Candidate site cannot meet criterion 
- Scoring Definitions for J:

$10=$ Candidate site meets criterion with minimal to no difficulty

$5=\mathrm{N} / \mathrm{A}$

$1=\mathrm{N} / \mathrm{A}$

0 = Candidate site cannot meet criterion

The values were then multiplied by the criteria weighting factors, and these product values were summed to provide an overall score for each candidate site. The siting areas with the highest scores (top $70 \%$ ) were considered the preferred candidate sites. Tables 4-6 summarize the results of this evaluation and identify the preferred advanced reactor sites, ranked from high to low and categorized by existing buildings, undeveloped sites, and previously developed sites, respectively.

Table 4. Summary evaluation matrix of preferred candidate sites - existing buildings.

\begin{tabular}{|c|c|c|c|c|c|c|c|}
\hline \multirow{2}{*}{\multicolumn{2}{|c|}{ EVALUATION MATRIX }} & \multicolumn{6}{|c|}{ PREFERRED CANDIDATE SITES } \\
\hline & & \multicolumn{6}{|c|}{ EXISTING BUILDINGS } \\
\hline WANT CRITERIA & WEIGHTS & \multicolumn{2}{|c|}{$2 *$} & \multicolumn{2}{|c|}{3 *** } & \multicolumn{2}{|c|}{1 ***⿰㇇⿰亅⿱丿丶丶 } \\
\hline A - Avoid areas of surface water flooding/ponding & 7.3 & 10 & 73 & 10 & 73 & 10 & 73 \\
\hline B - Maximize proximity to suitable sources of cooling water & 4.0 & 10 & 40 & 10 & 40 & 5 & 20 \\
\hline C - Minimize disturbance of critical habitat of protected species & 11.9 & 10 & 119 & 10 & 119 & 10 & 119 \\
\hline D - Avoid areas of high predictive archaeology zones & 13.2 & 10 & 132 & 10 & 132 & 10 & 132 \\
\hline E - Minimize potential adverse interactions with existing programs & 10.6 & 10 & 106 & 5 & 53 & 10 & 106 \\
\hline F - Ensure appropriate security controls are available & 15.2 & 10 & 152 & 10 & 152 & 5 & 76 \\
\hline G - Minimize distance from public transportation routes & 3.3 & 10 & 33 & 10 & 33 & 10 & 33 \\
\hline $\mathrm{H}$ - Minimize distance to transmission lines & 2.6 & 10 & 26 & 10 & 26 & 10 & 26 \\
\hline I - Optimize use of Land Use planning zones & 0.7 & 10 & 7 & 10 & 7 & 10 & 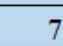 \\
\hline $\begin{array}{l}\text { J - Maximize use of updated seismic hazard analysis and site-specific } \\
\text { characterization data }\end{array}$ & 19.9 & 10 & 199 & 10 & 199 & 10 & 199 \\
\hline $\mathrm{K}$ - Minimize proximity to faults and building on soil sites & 11.3 & 10 & 113 & 10 & 113 & 10 & 113 \\
\hline TOTALS & 100.0 & & 1000 & & 947 & & 904 \\
\hline
\end{tabular}

MFC $\square$-INTEC $\square$-ATR Complex $\square$-CFA

Existing Buildings: *MFC-767 (EBR-II); **MFC-775/776 (ZPPR); ***PP-691 (FPR) 
Table 5. Summary evaluation matrix of preferred candidate sites - undeveloped sites.

\begin{tabular}{|c|c|c|c|c|c|c|c|c|c|}
\hline \multirow{2}{*}{\multicolumn{2}{|c|}{ EVALUATION MATRIX }} & \multicolumn{8}{|c|}{ PREFERRED CANDIDATE SITES } \\
\hline & & \multicolumn{8}{|c|}{ UNDEVELOPED SIIES } \\
\hline$\overline{\text { WANT CRITERIA }}$ & WEIGHTS & \multicolumn{2}{|c|}{10} & \multicolumn{2}{|c|}{9} & \multicolumn{2}{|c|}{11} & \multicolumn{2}{|c|}{8} \\
\hline A - Avoid areas of surface water flooding/ponding & 7.3 & 5 & 36 & 10 & 73 & 10 & 73 & 5 & 36 \\
\hline B - Maximize proximity to suitable sources of cooling water & 4.0 & 10 & 40 & 10 & 40 & 10 & 40 & 10 & 40 \\
\hline C - Minimize disturbance of critical habitat of protected species & 11.9 & 10 & 119 & 10 & 119 & 10 & 119 & 10 & 119 \\
\hline D - Avoid areas of high predictive archaeology zones & 13.2 & 10 & 132 & 10 & 132 & 10 & 132 & 10 & 132 \\
\hline E - Minimize potential adverse interactions with existing programs & 10.6 & 10 & 106 & 5 & 53 & 5 & 53 & 10 & 10 \\
\hline F - Ensure appropriate security controls are available & 15.2 & 5 & 76 & 5 & 76 & 5 & 76 & 5 & 76 \\
\hline G - Minimize distance from public transportation routes & 3.3 & 10 & 33 & 10 & 33 & 10 & 33 & 10 & 33 \\
\hline $\mathrm{H}$ - Minimize distance to transmission lines & 2.6 & 10 & 26 & 10 & 26 & 10 & 26 & 10 & 26 \\
\hline I - Optimize use of Land Use planning zones & 0.7 & 10 & 7 & 10 & 7 & 10 & 7 & 10 & 7 \\
\hline $\begin{array}{l}\mathrm{J} \text { - Maximize use of updated seismic hazard analysis and site-specific } \\
\text { characterization data }\end{array}$ & 19.9 & 10 & 199 & 10 & 199 & 10 & 199 & 10 & 199 \\
\hline $\mathrm{K}$ - Minimize proximity to faults and building on soil sites & 11.3 & 10 & 113 & 10 & 113 & 10 & 113 & 5 & 56 \\
\hline TOTALS & 100.0 & & $8 \mathbf{8 8 7}$ & & 871 & & 871 & & 735 \\
\hline
\end{tabular}

Table 6. Summary evaluation matrix of preferred candidate sites - previously developed sites.

\begin{tabular}{|c|c|c|c|c|c|}
\hline \multirow{2}{*}{\multicolumn{2}{|c|}{ EVALUATION MATRIX }} & \multicolumn{4}{|c|}{ PREFERRED CANDIDATE SITES } \\
\hline & & \multicolumn{4}{|c|}{ PREVIOUSLY DEVELOPED SITES } \\
\hline WANT CRITERIA & WEIGHTS & \multicolumn{2}{|c|}{6} & \multicolumn{2}{|c|}{32} \\
\hline A - Avoid areas of surface water flooding/ponding & 7.3 & 10 & 73 & 10 & 73 \\
\hline B - Maximize proximity to suitable sources of cooling water & 4.0 & 10 & 40 & 10 & 40 \\
\hline C - Minimize disturbance of critical habitat of protected species & 11.9 & 10 & 119 & 10 & 119 \\
\hline D - Avoid areas of high predictive archaeology zones & 13.2 & 10 & 132 & 10 & 132 \\
\hline E - Minimize potential adverse interactions with existing programs & 10.6 & 10 & 106 & 10 & 106 \\
\hline F - Ensure appropriate security controls are available & 15.2 & 5 & 76 & 5 & 76 \\
\hline G - Minimize distance from public transportation routes & 3.3 & 10 & 33 & 10 & 33 \\
\hline $\mathrm{H}$ - Minimize distance to transmission lines & 2.6 & 10 & 26 & 10 & 26 \\
\hline I - Optimize use of Land Use planning zones & 0.7 & 10 & 7 & 10 & 7 \\
\hline $\begin{array}{l}\text { J - Maximize use of updated seismic hazard analysis and site-specific } \\
\text { characterization data }\end{array}$ & 19.9 & 0 & 0 & 0 & 0 \\
\hline $\mathrm{K}$ - Minimize proximity to faults and building on soil sites & 11.3 & 5 & 56 & 5 & 56 \\
\hline TOTALS & 100.0 & & 669 & & 669 \\
\hline
\end{tabular}

\section{$\square$-MFC $\square$ - INTEC $\square$-ATR Complex $\square$-CFA}

Existing Buildings: *MFC-767 (EBR-II); **MFC-775/776 (ZPPR); ***CPP-691(FPR) 


\subsection{Evaluation Results Summary}

\subsubsection{SME Evaluation Results}

As shown in Table 4, the top three ranked options include existing buildings, MFC-767 (EBR-II), MFC-775/776 (ZPPR), and CPP-691 (FPR), in that order. In addition, the next four preferred candidate sites are located adjacent to MFC (sites \#10, \#9, and \#11) and the ATR Complex (site \#8), respectively. The comparatively high scores at these locations are primarily due to existing site-specific characterization data, existing seismic hazard analysis data, and proximity to existing infrastructure (i.e., utilities, roads, security, etc.).

The previously developed candidate sites located at CFA (sites \#6 and \#32) did not rank far behind mainly due to proximity to existing infrastructure and subject matter expert (SME) knowledge of site characteristics. Appendix C contains area maps of the preferred candidate sites.

As follow-up to a management comment, the INL Regulatory Compliance Department completed an analysis on the potential radiation dose to public receptor occupants of site \#31, south of MFC. Based on Environmental Protection Agency (EPA) regulations (40 CFR Part 61), impact to the public due to radiation dose to public receptors if site \#31 is selected as an advanced reactor demonstration site will be less than the EPA standard for dose to the public. MFC operations should not be affected. (Verdoorn 2020) The summary results of the Clean Air Act Assessment Package-88 (CAP88) are included in Appendix D.

\subsubsection{Noted Structural Challenges with Existing Building Preferred Sites}

Prior to siting an advanced reactor at one of the existing building preferred sites, the noted challenges listed below may need to be addressed:

Site \#2 MFC-767 (EBR-II)

- There currently is no program in the facility.

- $\quad$ The access door is $8 \times 10-\mathrm{ft}$.

- Modifying EBR-II may require a cultural resource review due to its eligibility for nomination to the National Register of Historic Places (NRHP) (DOE-ID 2016b). If additional instructions and requirements are identified as a result of the review, project personnel may be required to incorporate them into project plans or work control documents.

- A CERCLA site is embedded in the concrete below the basement floor.

- A building specific security posture would have to be stood up, if required by a new mission.

Site \#3 MFC-775/776 (ZPPR)

- The facility is currently in use.

- $\quad$ The largest access door is approximately $6 \times 7$-ft.

- It is anticipated that structural modifications will be required to the Reactor Cell Filter Structure.

- The Reactor Cell Filter Structure has a significant amount of asbestos, which would need to be remediated.

- The Reactor Cell Filter Structure has hundreds of wood-framed HEPA filters that may need to be replaced, depending on the mission.

- Modifying ZPPR may require a cultural resource review due to its eligibility for nomination to the NRHP (DOE-ID 2016b). If additional instructions and requirements are identified as a result 
of the review, project personnel may be required to incorporate them into project plans or work control documents.

- Non-U.S. citizens are currently prohibited access to the ZPPR facility.

- A significant security posture currently exists at the ZPPR facility.

Site \#1 CPP-691 (FPR)

- The building is located at INTEC, which is managed and operated by the Department of Energy Office of Environmental Management (DOE-EM).

- The large access door on the south side of the building is approximately $10 \times 15$-ft.

- The Calcine Disposition Project's retrieval demonstration in full size, using temporary calcine retrieval equipment, is mocked up in CPP-691. This effort is funded by DOE-EM and has equipment installed in cell 7 , piping runs through parts of the facility, and other equipment staged on cell hatches. There is no clear timeframe for the completion of the work, but it is only using a portion of the facility.

- A SSHAC Level 3 analysis has not been done at INTEC. The current plan for completing the SSHAC Level 3 analysis does not include INTEC. If CPP-691 will be offered as an advanced reactor siting location, an additional borehole for site-specific seismic analyses should be added to the SSHAC Level 3 work plan and analysis. Adding the scope now to the work plan is estimated to be significantly less expensive than waiting and conducting a separate SSHAC Level 3 analysis at INTEC.

- A security posture would have to be implemented.

\section{General Challenges}

- Independent of the building selected, it was suggested that an area be reserved, near the candidate site of interest, for estimating the effects of a proposed advanced reactor on nearby missions.

- Clarification is needed on what determines the "nearest public member" and definition of a collocated worker. DOE regulations specify a general employee can be someone working in conjunction with DOE. NRC specifies, when receiving an occupational dose, that member is not a member of the public. The Defense Nuclear Facilities Safety Board (DNFSB) specifically includes a description of workers as being traditionally inside the boundary of a potential release, and a collocated worker as being at 100 meters from the potential release. This may need the Department of Energy Idaho Operations Office (DOE-ID) to make an official determination (Kropp 2019).

- Based on INL security access requirements, the preferred existing building locations are focused on housing DOE-authorized reactor demonstrations.

\subsection{Sensitivity Analysis}

The following subsections document the results of analyses that evaluate the sensitivity of the overall weighted utility scores for each alternative, relative to changes in criteria weights and alternative scores. As such, these analyses help the decision-maker understand the conditions under which the highest scoring alternative might be replaced by a competing alternative. If the highest scoring alternative remains on top over a broad range of changes, the alternative is considered a "robust" solution with less uncertainty about that alternative being the best decision. The findings and conclusions from these analyses are summarized below by criteria weighting sensitivity and alternative scoring sensitivity. Table 7 defines the scale used to describe the observed sensitivities. 
Table 7. Sensitivity description definitions.

\begin{tabular}{|c|c|c|}
\hline Description & Difference is > & But $\leq$ \\
\hline Completely Insensitive & \multicolumn{2}{|c|}{$\begin{array}{l}\text { Top scoring alternative does not change over full range ( } 0 \% \text { to } \\
100 \% \text {, including end points) }\end{array}$} \\
\hline Very Insensitive & 0.75 & 1.00 \\
\hline Moderately Insensitive & 0.35 & 0.75 \\
\hline Somewhat Sensitive & 0.15 & 0.35 \\
\hline Sensitive & 0.05 & 0.15 \\
\hline Very Sensitive & 0.00 & 0.05 \\
\hline
\end{tabular}

\subsubsection{Criteria Weighting Sensitivity}

The criteria weighting sensitivity analysis was performed by parametrically varying (in $5 \%$ increments) each criterion weight, one-at-a-time, from 0 to $100 \%$. When the criterion being analyzed carried less than $100 \%$ of the total weight, the other criteria are allocated the remaining weight proportional to their originally assigned weight values. The overall alternative scores were recalculated for each incremental change and charted so that changes in the highest scoring alternative could be easily identified. The following charts show the results of the parametric criteria weighting sensitivity analysis.

As shown in the following charts, Figures 16-26, the criteria weighting sensitivity analysis suggests that top ranked site \#2 MFC-767 and second ranked site \#3 MFC-775/776 are positioned as robust top scoring alternatives. The first and second place alternatives are better choices as evidenced by the lack of transitions between the top two scoring alternatives and the remaining sites regardless of the criterion weight setting. Due to undefined advanced reactor design requirements and siting-specific needs, it is no surprise that criteria weight sensitivities arise in the lower ranked candidate site locations where more uncertainty might exist.

Figure 16 shows the top two scoring candidate sites (MFC-767 and MFC-775/776) are completely insensitive to "Avoid areas of surface water flooding/ponding” criterion weighting uncertainties/errors. There is no change that can be made to the established weight (7.3\%) which results in a different alternative becoming the top scoring alternative. The next top scoring alternative, 10-MFC - North Sites, is very sensitive to changes in this criterion. The established weight would require a downward or upward adjustment of only 3\% before another site becomes more desirable (in this case site \#1 CPP-691 or site \#11 MFC - East Sites, respectively). 


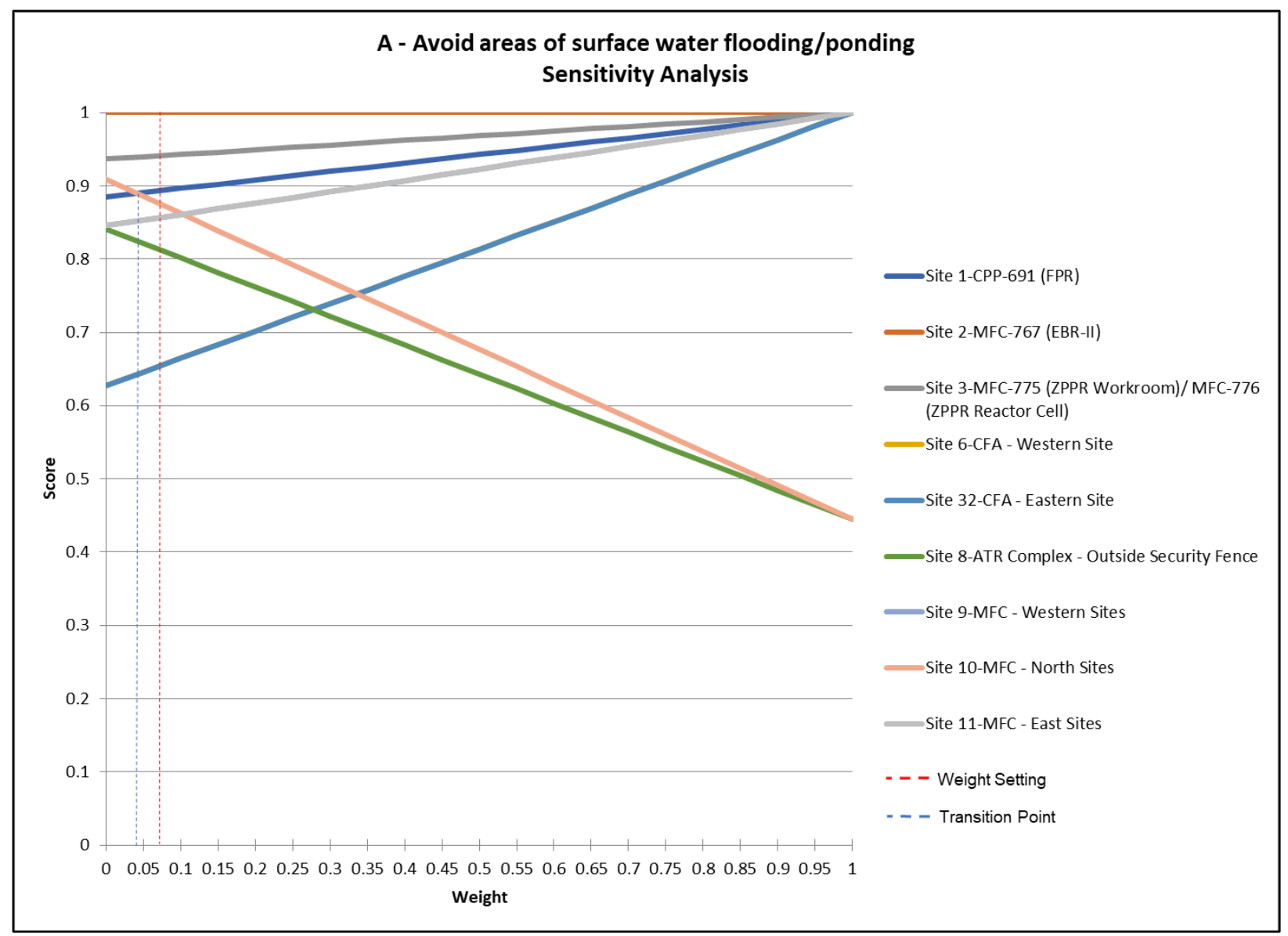

Figure 16. “Avoid areas of surface water flooding/ponding” criterion weight sensitivity with transition points identified relative to assigned weight setting.

Figure 17 shows that the top two scoring candidate sites (MFC-767 and MFC-775/776) are completely insensitive to "Maximize proximity to suitable sources of cooling water" criterion weighting uncertainties/errors. There is no change that can be made to the established weight (4\%) which results in a different alternative becoming the top scoring alternative. The next top scoring alternative, site \#1 CPP-691 (FPR), is very sensitive to changes in this criterion. The established weight would require an upward adjustment of only 3\% before another site becomes more desirable (in this case site \#10 MFC North Sites). 


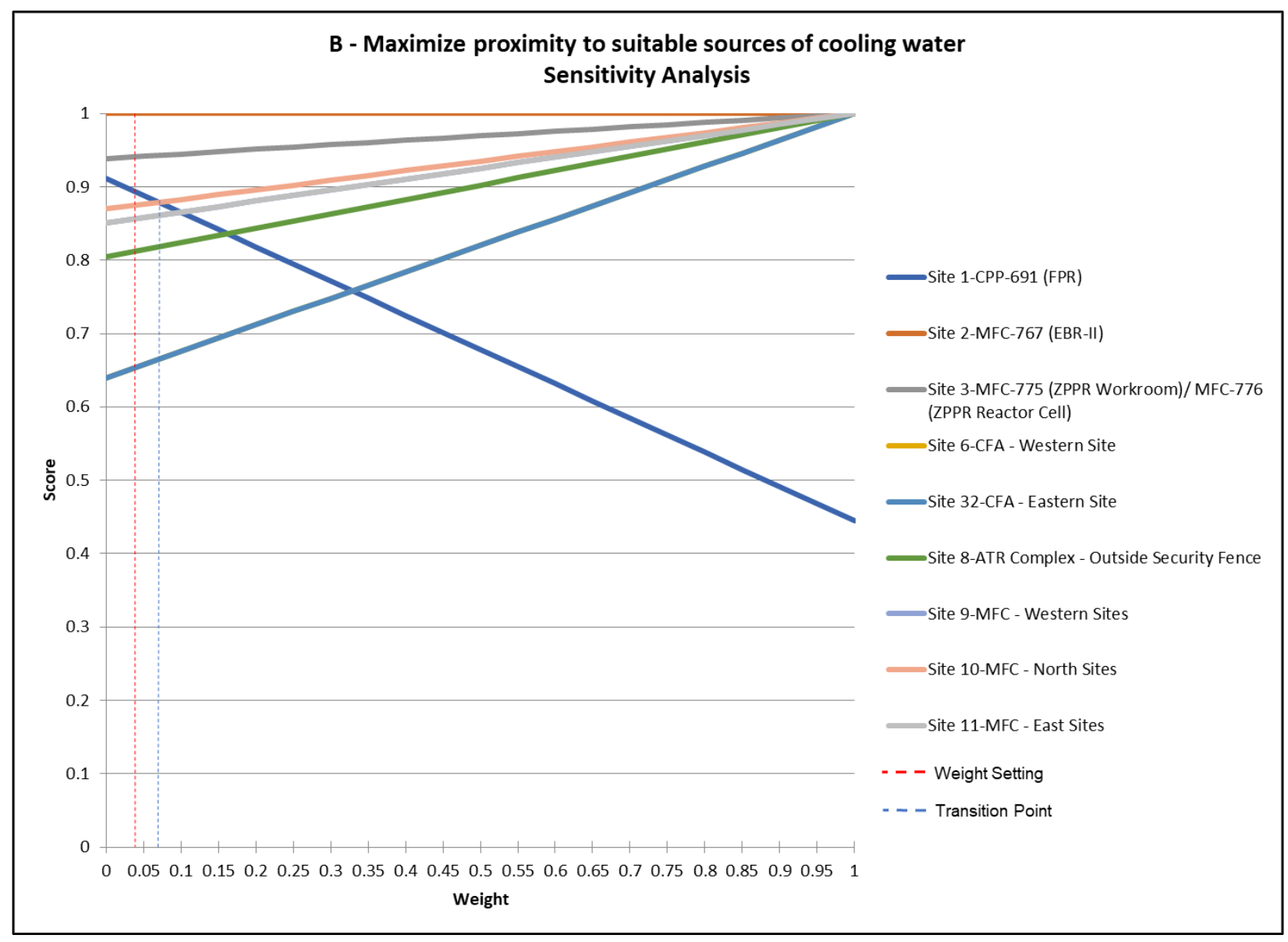

Figure 17. "Maximize proximity to suitable sources of cooling water" criterion weight sensitivity with transition points identified relative to assigned weight setting.

Figures 18 and 19 illustrate that the top scoring candidate site (MFC-767) is completely insensitive to "Minimize disturbance of critical habitat of protected species" and "Avoid areas of high-predictive archaeology zones" criteria weighting uncertainties/errors. There is no change that can be made to the established weights (11.9\% and $13.2 \%$, respectively) which results in a different alternative becoming the top scoring alternative. 


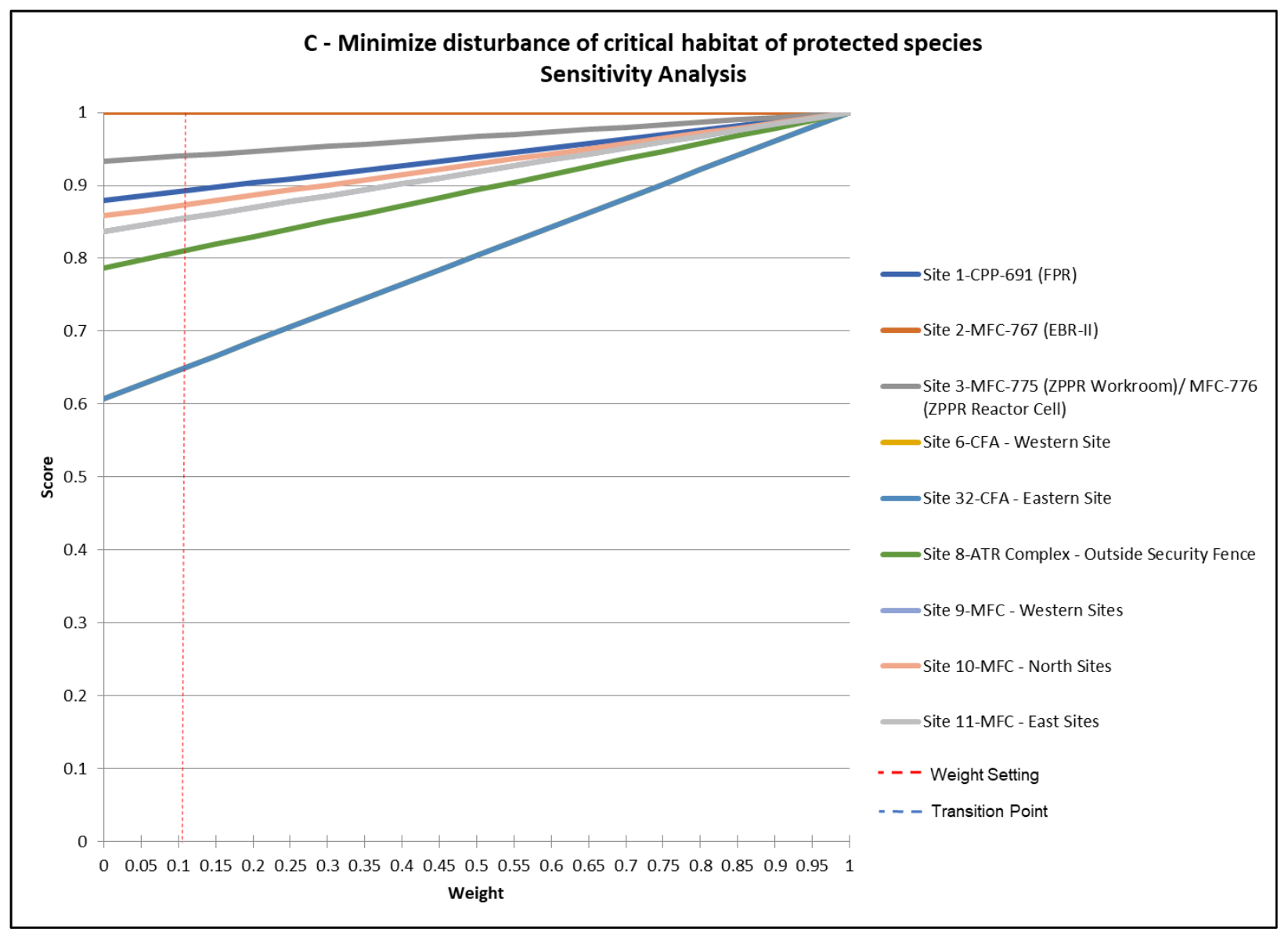

Figure 18. "Minimize disturbance of critical habitat of protected species" criterion weight sensitivity with transition points identified relative to assigned weight setting. 


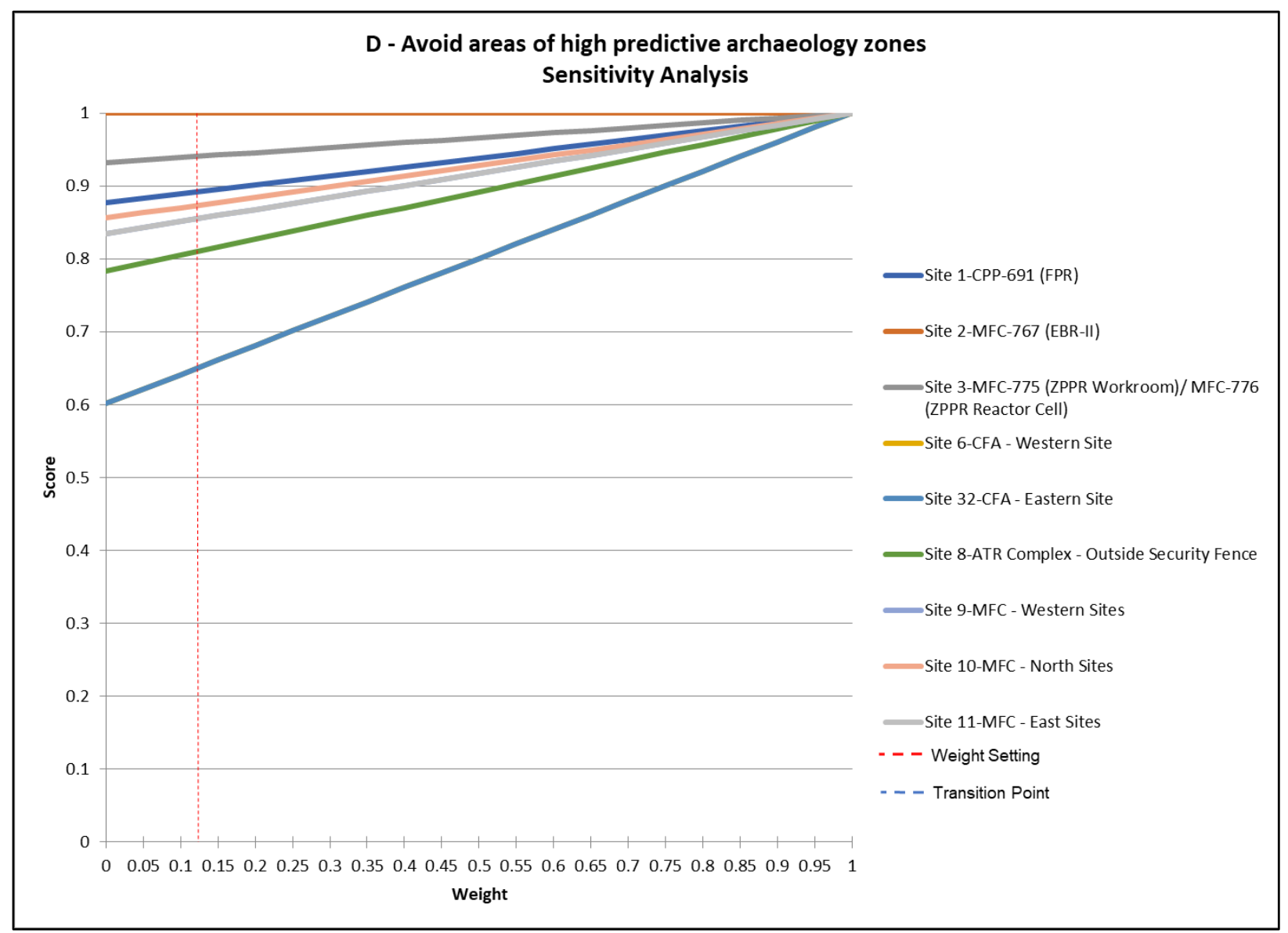

Figure 19. “Avoid areas of high predictive archaeology zones” criterion weight sensitivity with transition points identified relative to assigned weight setting.

Figure 20 illustrates that the top scoring candidate site (MFC-767) is completely insensitive to "Minimize potential adverse interactions with existing programs" criterion weighting uncertainties/errors. There is no change that can be made to the established weight (10.6\%) which results in a different alternative becoming the top scoring alternative. The next top scoring alternative, site \#3 MFC-775/776, is sensitive to changes in this criterion. The established weight would require an upward adjustment of 7\% before another site becomes more desirable (in this case site \#1 CPP-691). 


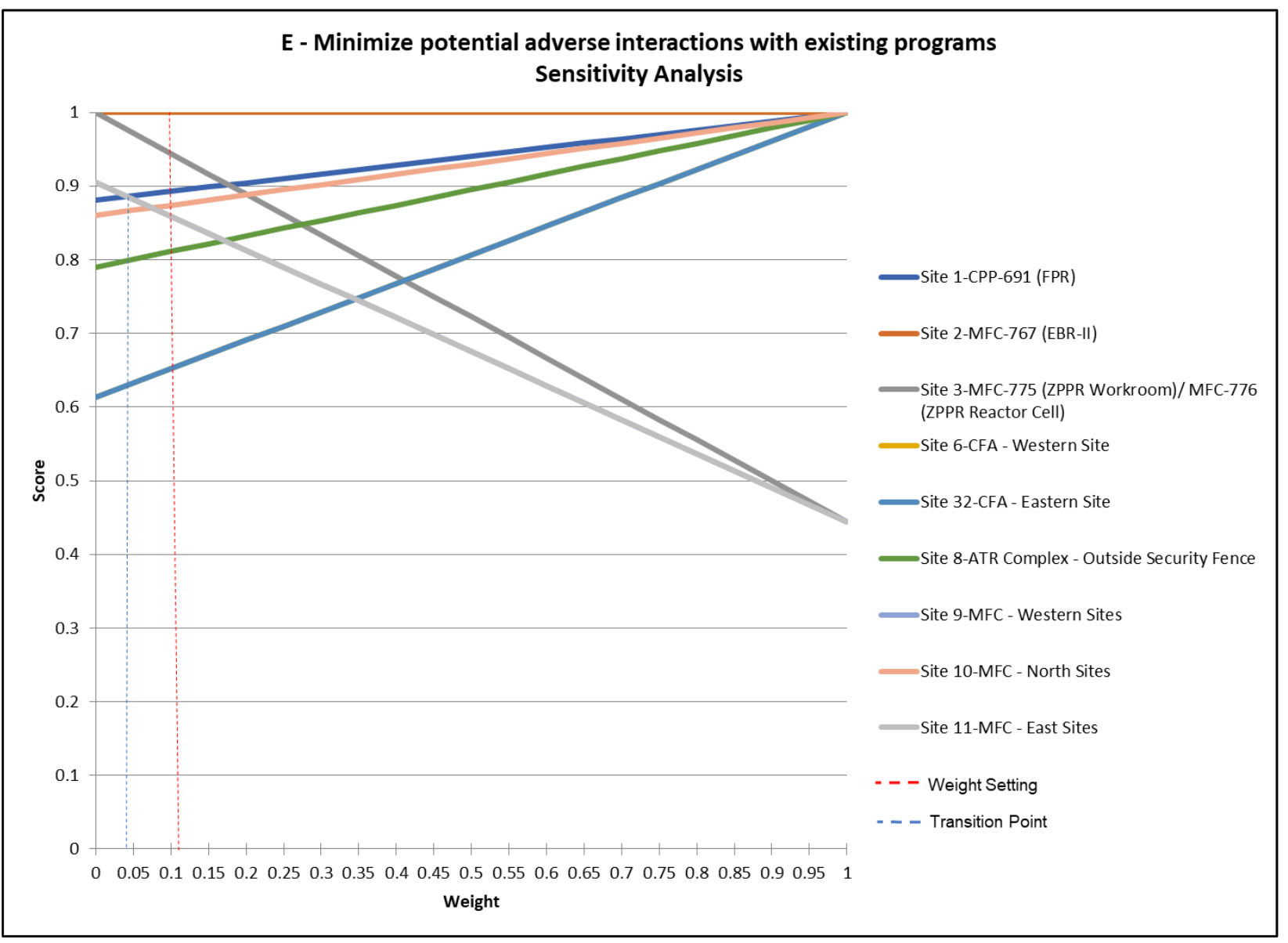

Figure 20. "Minimize potential adverse interactions with existing programs" criterion weight sensitivity with transition points identified relative to assigned weight setting.

Figure 21 illustrates that the top scoring candidate site (MFC-767) is completely insensitive to "Ensure appropriate security controls are available" criterion weighting uncertainties/errors. There is no change that can be made to the established weight (15.2\%) which results in a different alternative becoming the top scoring alternative. The next top scoring alternative, site \#1 CPP-691, is sensitive to changes in this criterion. The established weight would require a downward adjustment of $7 \%$ before another site becomes more desirable (in this case site \#3 MFC-775/776). 


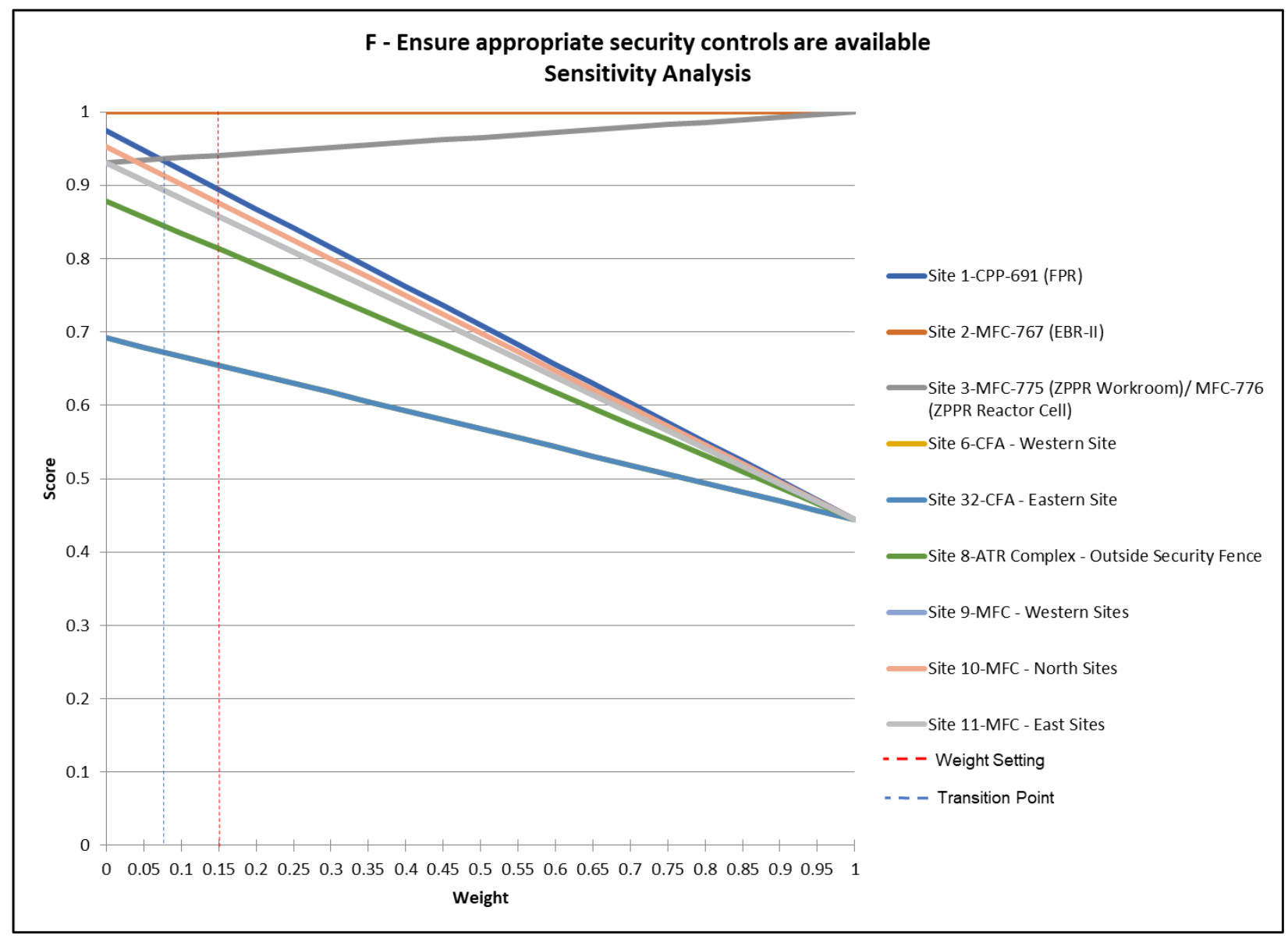

Figure 21. "Ensure appropriate security controls are available" criterion weight sensitivity with transition points identified relative to assigned weight setting.

Figures 22-24 illustrate that the top scoring alternative (i.e., MFC-767) is completely insensitive to "Minimize disturbance from transportation routes," "Minimize distance from transmission lines," and "Optimize use of Land Use planning zones" criteria weighting uncertainties/errors. There is no change that can be made to the established weights (3.3\%, $2.6 \%$, and $0.7 \%$, respectively) which results in a different alternative becoming the top scoring alternative. 


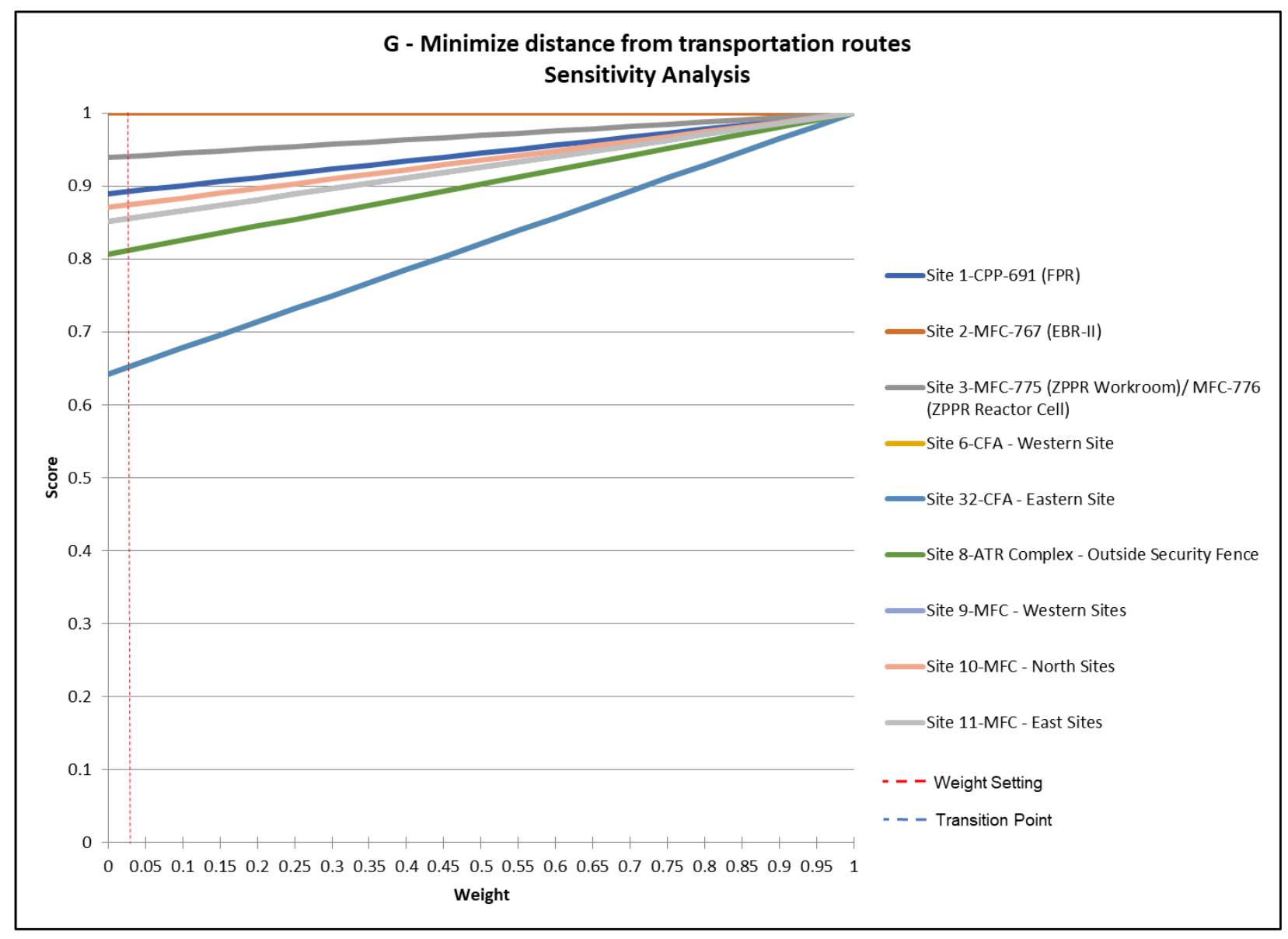

Figure 22. "Minimize distance from transportation routes" criterion weight sensitivity with transition points identified relative to assigned weight setting. 


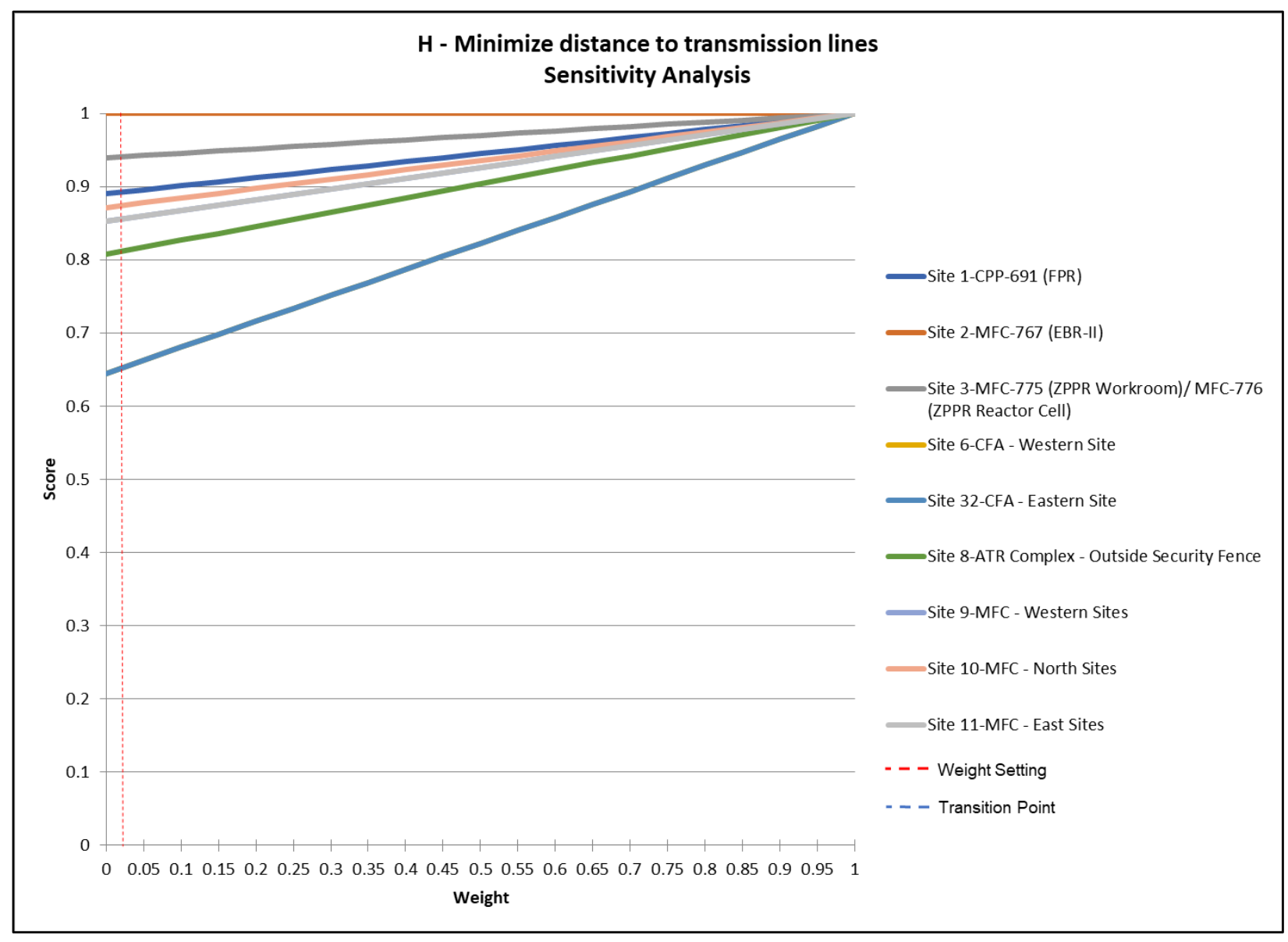

Figure 23. "Minimize distance to transmission lines" criterion weight sensitivity with transition points identified relative to assigned weight setting. 


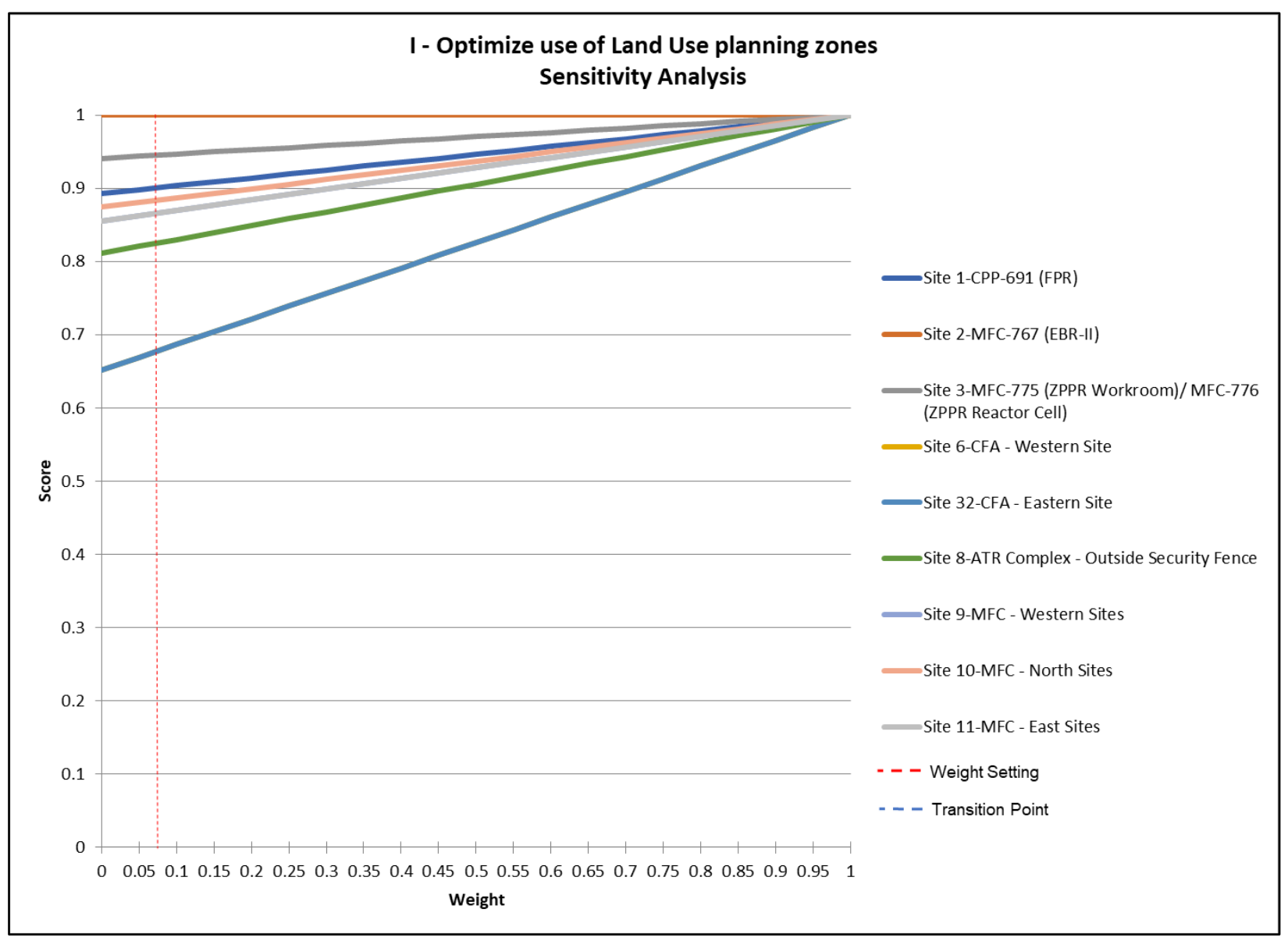

Figure 24. "Optimize use of Land Use planning zones” criterion weight sensitivity with transition points identified relative to assigned weight setting.

Figure 25 illustrates that the top five scoring candidate sites are completely insensitive to "Maximize use of updated seismic hazard analysis and site-specific characterization data" criterion weighting uncertainties/errors. There is no change that can be made to the established weight (19.9\%) which results in a different alternative becoming the top scoring alternative. 


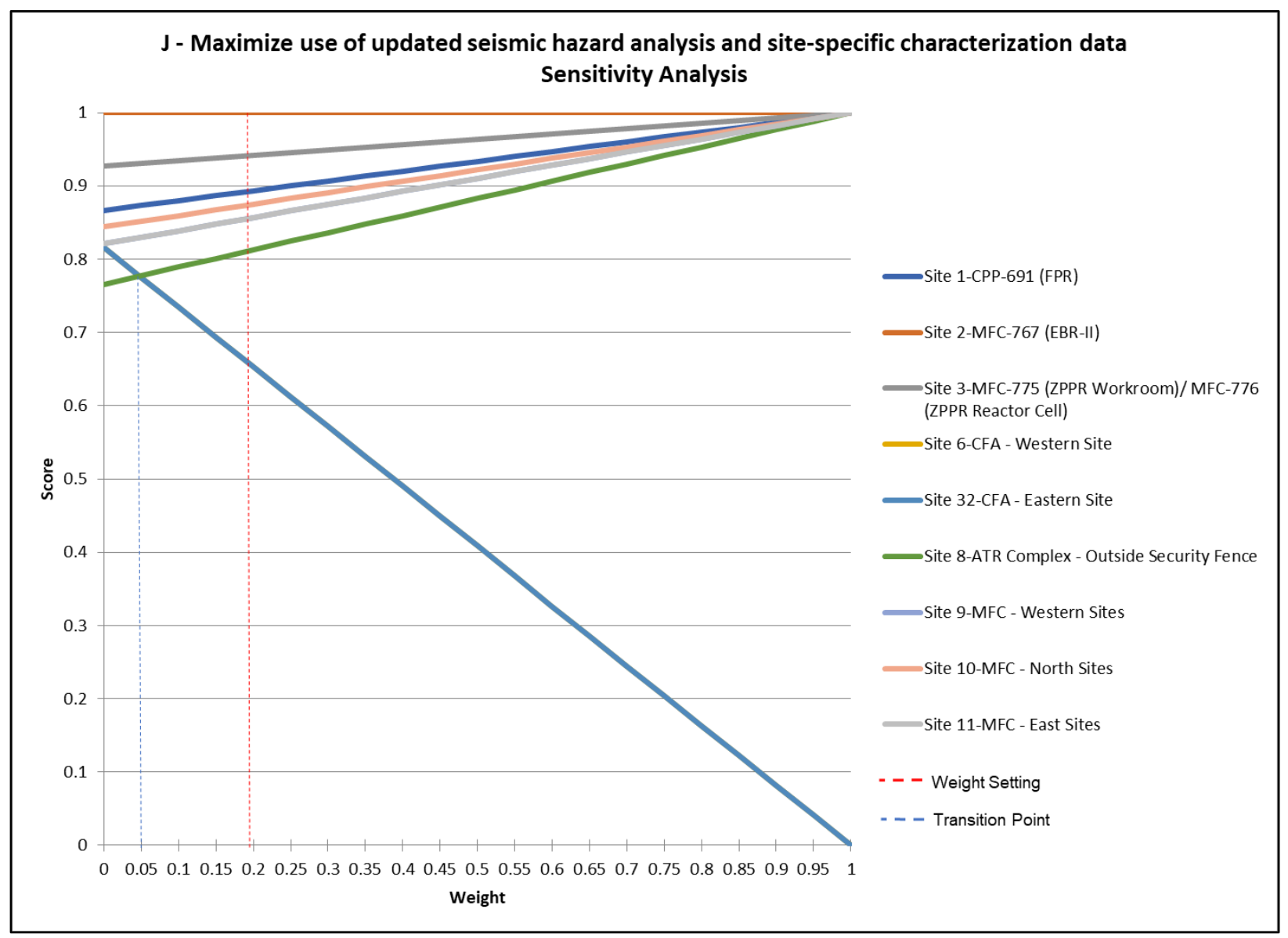

Figure 25. "Maximize use of updated seismic hazard analysis and site-specific characterization data" criterion weight sensitivity with transition points identified relative to assigned weight setting.

Figure 26 illustrates that the top four scoring candidate sites are completely insensitive to "Minimize proximity to faults and building on soil sites" criterion weighting uncertainties/errors. There is no change that can be made to the established weight (11.3\%) which results in a different alternative becoming the top scoring alternative 


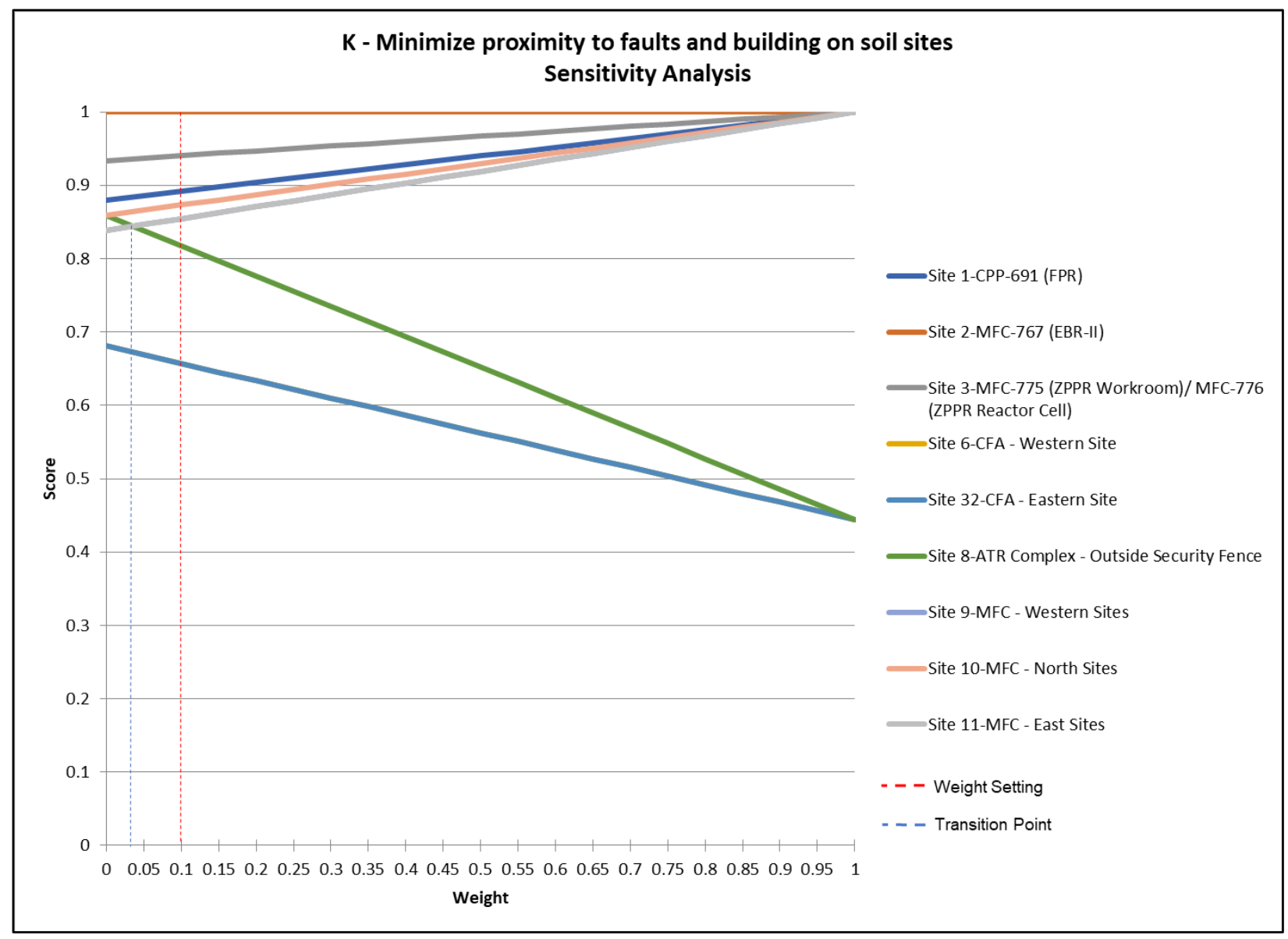

Figure 26. "Minimize proximity to faults and building on soil sites" criterion weight sensitivity with transition points identified relative to assigned weight setting.

\subsubsection{Alternative Scoring Sensitivity}

The alternative scoring sensitivity analysis was performed by parametrically varying by $\pm 20 \%$ each alternative's criteria score (up to a maximum of 1 ) one-at-a-time holding all other values constant. The overall weighted utility scores were recalculated for each change and charted including error bars to allow comparison of the alternative scores including uncertainty. This type of analysis is a standard output of the QuickCompare ${ }^{\circledR}$ tool. 
Figure 27 illustrates the results of the parametric scoring sensitivity analysis. It shows that a $\pm 20 \%$ score uncertainty between the top two scored sites (site \#2 MFC-767 and site \#3 MFC-775/776) produces no overlaps in the error bars demonstrating these sites score higher than other sites in the face of $\pm 20 \%$ scoring uncertainty.

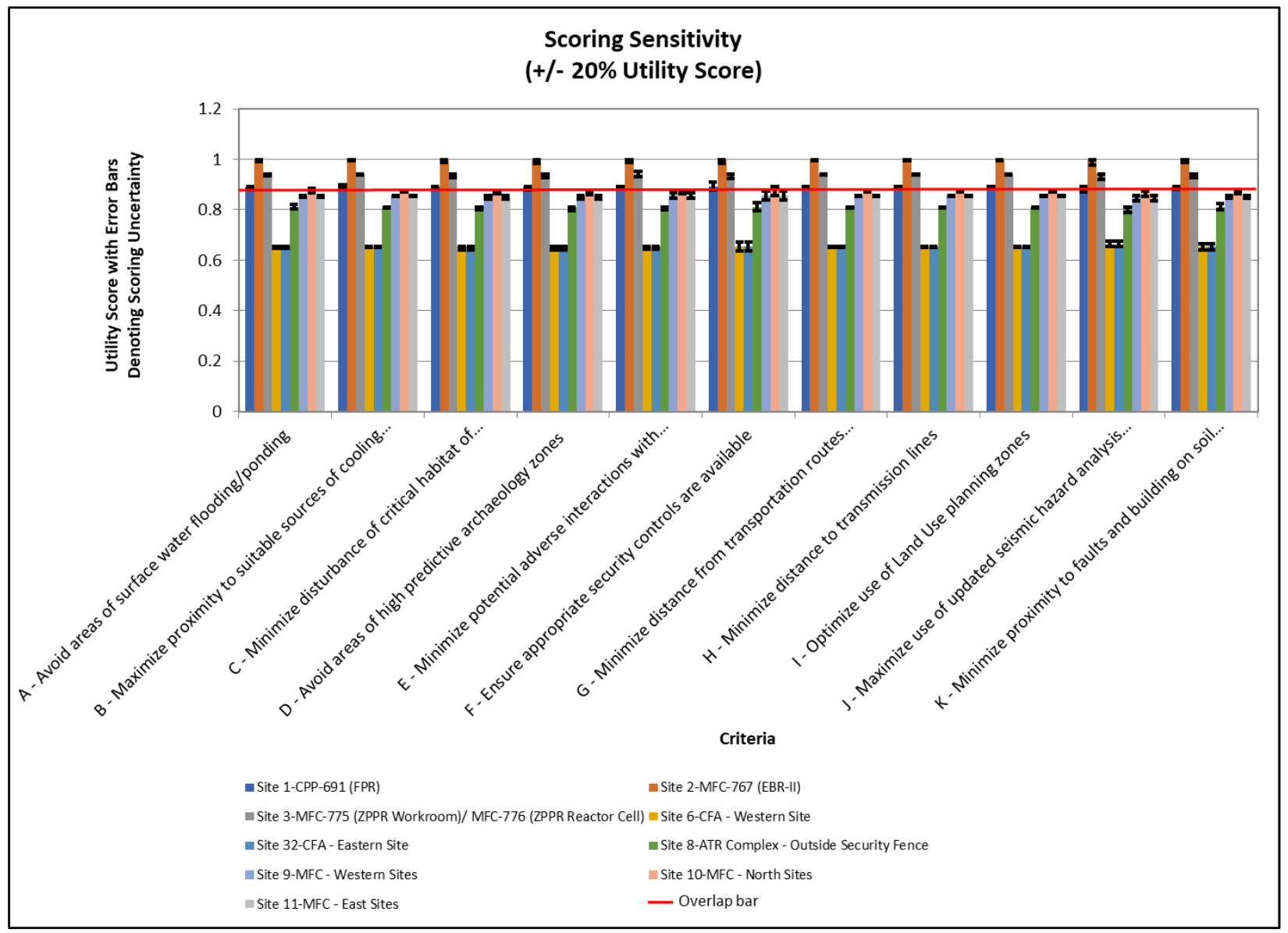

Figure 27. Alternative scoring sensitivity analysis.

The overlap in error bars between the third and fourth top ranked sites (site \#1 CPP-691 and site \#10 MFC - North Sites, respectively) when varying the alternative criteria scores in relation to "Ensure appropriate security controls are available” can be explained by the unavailability of specific security control requirements of the individual advanced reactor demonstrations.

\subsection{Seismic Structural Scoping Studies}

In addition to the SME candidate sites evaluation, INL subcontracted with Simpson Gumpertz \& Heger, Inc. (SGH) to perform seismic structural scoping studies to support research activities associated with the development of an advanced reactor program. The objective of each seismic scoping study was to provide the advanced reactor program with a qualitative assessment of the facilities such that a determination could be made on what codes they might be able to meet and on the usability of each of the facilities.

The following descriptions were used with respect to the structural adequacy of the facilities:

- The structure is "Robust,” meaning it would probably withstand DOE performance category (PC)-3 seismic event 
- The facility is "Pretty Good,” meaning it may withstand a PC-3 seismic event if detailed calculations are performed, but would most likely withstand a PC-2 event

- The facility is "OK," meaning it will not withstand a PC-3 event, and may not withstand a PC-2 event even if detailed calculations are performed

- The facility is “At Risk,” meaning it will most likely not withstand even a PC-2 event.

It should be noted that, once a facility is chosen, detailed structural calculations will need to be performed in accordance with DOE/NRC requirements, based upon the facility's performance categorization.

The four existing buildings that passed the "Must" criteria screening activity were analyzed: CPP691, MFC-767, MFC-775/776, and PBF-613. The following subsections summarize the results for each building. The detailed analyses can be found in the referenced letter reports identified below.

\subsubsection{CPP-691 (FPR) Seismic Structural Scoping Study}

In order to determine whether the CPP-691 facility can withstand a PC-2 or PC-3 seismic event, SGH compared the factored design loads used by Ralph M. Parsons to the current factored design load requirements. Based on these design load comparisons, CPP-691 is "Robust," meaning it would probably withstand a PC-3 level event.

If this structure is chosen for the advanced reactor program, a more detailed structural investigation and analysis should occur which would include (but not be limited to) the following items:

- Identify and find missing drawings and calculations for structural steel and concrete designs. Alternatively, conduct site visits to identify needed-as-built structural designs.

- Check existing structure for compliance with drawings.

- Perform a more detailed structural walkdown to investigate for structural degradation or distress.

- Identify and define loading requirements and criteria (i.e., Does the structure need to comply with DOE and NRC?)

- Perform detailed calculations to determine whether the low roofs are adequately designed to support snow drift loads.

- Review existing structural connection details and perform further calculations to determine whether current seismic detailing requirements for steel and reinforced concrete are met.

- Perform a more detailed seismic analysis (including soil-structure interaction effects) to calculate PC-3 seismic demands should this structure be chosen for the advanced reactor building. Since SGH calculations considered a simplified fixed-base calculation in order to obtain an estimate of the seismic demands, a more detailed seismic analysis would be required.

The complete seismic scoping study can be found in the SGH report titled, "002MAEvans-L191931.00 - CPP-691, FPR Facility Seismic Structural Scoping Study.”

\subsubsection{MFC-767 (EBR-II) Seismic Structural Scoping Study}

SGH reviewed documents associated with the original construction and modifications to identify the structural system and load path. The dome structure transfers vertical dead and snow load down through the reinforced concrete walls and steel shell to the foundation through axial compression. The structure resists global overturning, due to lateral wind and seismic demands through axial tension and 
compression in the concrete walls and steel shell. It resists global shear through the shear in the concrete walls and steel shell. Global demands are transferred down to the foundation at grade.

SGH performed a limited walkdown of the structure, and other than areas designated for repair as part of the SGH repairs, they did not observe any distress or deterioration that appeared as if it would affect the capacity of the structure.

They reviewed applicable codes and standards to identify PC-2 and PC-3 criteria for wind and seismic and calculated applicable dead, live, roof live, rain and snow loads. They used conservative values for PC-3 seismic spectra. They also calculated the controlling loads on the structure, based on applicable load combinations, and performed a structural evaluation. They conservatively considered the reinforced concrete cylindrical walls when evaluating the structure walls, neglecting the contribution to strength from the steel cylinder.

SGH evaluated the global overturning; compression, tension, and shear in the reinforced concrete cylinder; and membrane and bending stress in the dome of the MFC-767 structure. The structure is "Robust," meaning it would probably withstand a PC-3 seismic event once the structure is repaired as discussed in the referenced report. The evaluation is based on conservative input response spectra. Note that the structure is considered "Pretty Good" for tornado missile impact since further calculations would be required to determine if the structure can withstand the design missile impacts. If this structure is chosen to provide a future use, a more detailed walkdown should be performed to obtain a better sense of the overall structural condition and confirm implementation of the repairs and security of the polar crane, and a detailed structural analysis should be performed based on selected design criteria.

The complete seismic scoping study can be found in the SGH report titled, "001CHRoy-L-191931.00 - MFC-767, EBR-II Seismic Structural Scoping Study.”

\subsubsection{MFC-775/776 (ZPPR) Seismic Structural Scoping Study}

The MFC-775/776 complex has two distinct structures, the Workroom/Vault (MFC-775) and the Reactor Cell (MFC-776).

\section{MFC-775, ZPPR Workroom/Vault}

Based on the updated Demand/Capacity Ratio (DCR) calculations, the MFC-775 ZPPR Vault/Workroom structure is "Pretty Good," meaning it may withstand a PC-3 seismic event if detailed calculations are performed but would most likely withstand a PC-2 event.

If this structure is chosen for the advanced reactor program, a more detailed structural investigation and analysis should occur, which would include (but not be limited to) the following items:

Perform a more detailed structural walkdown to investigate for structural degradation or distress.

- Identify and define loading requirements and criteria (i.e., does the structure need to comply with DOE and NRC requirements). Determine whether the use of PC-3 Design Basis Earthquake (DBE) existing and PC-2 DBE existing seismic demands for the repurposing of an existing structure are appropriate.

- Perform a field investigation to determine effective lateral soil pressures on the north wall and perform detailed calculations to determine whether the design of the north wall is adequately designed to support out-of-plane shear loads for PC-3-level seismic demands and nonseismic lateral soil loads.

Review existing structural connection details and perform further calculations to determine whether current seismic detailing requirements are met.

The complete seismic scoping study can be found in the SGH report titled, "004MAEvans-L191931.00 - MFC-775 ZPPR Vault/Workroom Seismic Structural Scoping Study.” 


\section{MFC-776, ZPPR Reactor Cell}

In order to determine whether the ZPPR reactor cell can withstand a PC-2 or PC-3 seismic event, a comparison of the design loads considered in the original design calculations and the 2005 ARES scoping study (ARES Corporation 2005) to the current design load requirements was completed. Based on these design load comparisons, the ZPPR reactor cell is “At Risk," meaning it will most likely not withstand even a PC-2 event. This evaluation is primarily governed by the splices of the steel cable roof using clamps, which are no longer accepted in ASCE 19-16, and the backup containment, which has unknown capacity for lateral loading. If this structure is chosen for the advanced reactor program, a more detailed structural investigation and analysis should occur, which would include, but not be limited to, the following items:

- Identify and find missing drawings and calculations for structural steel and concrete designs. Alternatively, conduct site visits to identify needed as-built structural designs.

- Check existing structure for compliance with drawings.

- Perform a more detailed structural walkdown to investigate for structural degradation or distress. Expose and inspect a sample of cable splices.

- Identify and define loading requirements and criteria (i.e., does the structure need to comply with DOE and NRC requirements?)

- Perform detailed calculations to determine whether the steel cable roof is adequately designed to support dead and seismic loads and the backup containment is adequately designed to resist lateral seismic loads.

- Review existing structural connection details and perform further calculations to determine whether current seismic detailing requirements for steel and reinforced concrete are met.

- $\quad$ Perform the required more detailed seismic analysis (including soil-structure interaction effects) to calculate PC-3 seismic demands as well as comparable or higher seismic demands should this structure be chosen for the advanced reactor building. Current SGH calculations consider a simplified comparison with prior evaluations of the structure in order to obtain an estimate of the seismic demands.

The complete seismic scoping study can be found in the SGH report titled, "005BPDolphyn-L191931.00 - MFC-776, ZPPR Reactor Cell Seismic Structural Scoping Study.”

\subsubsection{PBF-613 Seismic Structural Scoping Study}

Based on the evaluations of the PBF-613 structure, the structure is "Pretty Good," meaning it may withstand a PC-3 seismic event if detailed calculations are performed but would most likely withstand a PC-2 event.

If this structure is chosen for the advanced reactor program, detailed calculations should be performed to determine whether the lateral force resisting system is adequate to transfer seismic loads to the foundation. Additionally, existing structural connection details should be reviewed, and further calculations should be performed to determine whether current seismic detailing requirements for steel, reinforced concrete and reinforced masonry are met.

The complete seismic scoping study can be found in the SGH report title, "003ERMcCarthy-L191931.00 - SPERT IV Area, Power Burst Facility 613, Seismic Structural Scoping Study.” 


\section{RECOMMENDATIONS}

Based on this analysis, it is recommended at this time that advanced reactor demonstrations planning to come to INL strongly consider utilizing one of the following preferred locations, listed from highest to lowest score:

- $\quad$ Site \#2 - MFC-767 (EBR-II)

- $\quad$ Site \#3 - MFC-775/776 (ZPPR)

- $\quad$ Site \#1 - CPP-691 (FPR)

- Site \#10 - Undeveloped area north of MFC

- Site \#9 - Undeveloped area west of MFC

- Site \#11 - Undeveloped area east of MFC

- $\quad$ Site \#8 - Undeveloped area west of the ATR Complex

- Site \#6 - Previously developed area west of CFA

- Site \#32 - Previously developed area east of CFA.

Of note, specific design characteristics of a particular reactor may make a slightly lower scoring location more attractive than a higher scoring location. The scores provide a general basis for site selection.

One option to consider to streamline adoption of these sites is to obtain an NRC Early Site Permit (ESP). An ESP requires SSHAC Level 3 compliant site-characterization data, which currently exists for these candidate sites. However, an ESP can be expeditiously developed for one or more of these sites with existing data. Additional sites could be added if identified and seismic characterization is funded by Spring 2020. The next opportunity for including additional undeveloped sites to the list of preferred siting options will occur after the completion of the SSHAC Level 3 analysis, tentatively planned to complete in February 2022.

The preferred sites listed above, and available site characterization data will be made available to developers granted INL use permits by DOE. Final selection of a reactor demonstration site for a specific advanced reactor will be made in consultation with DOE and in accordance with the site selection process established in the applicable authorized INL use agreement.

\section{REFERENCES}

10 CFR Part 20. U.S. Code of Federal Regulations, Title 10, “Energy,” Part 20, "Standards for Protection Against Radiation."

10 CFR Part 50. U.S. Code of Federal Regulations, Title 10, "Energy,” Part 50, "Domestic Licensing of Production and Utilization Facilities," Appendix A, "General Design Criteria for Nuclear Power Plants.”

10 CFR Part 51. U.S. Code of Federal Regulations, Title 10, “Energy,” Part 51, "Environmental Protection Regulations for Domestic Licensing and Related Regulatory Functions."

10 CFR Part 52. U.S. Code of Federal Regulations, Title 10, “Energy,” Part 52, "Licenses, Certifications, and Approvals for Nuclear Power Plants."

10 CFR Part 100. U.S. Code of Federal Regulations, Title 10, “Energy,” Part 100, “Reactor Site Criteria.” 
40 CFR Parts 1500-1508. U.S. Code of Federal Regulations, Title 40, "Protection of Environment,” Parts 1500-1508, "Regulations for Implementing NEPA," Council on Environmental Quality, Washington DC.

40 CFR Part 61, Subpart H. U.S. Code of Federal Regulations, Title 40, “Protection of Environment,” Part 61, "National Emission Standards for Emissions of Radionuclides Other Than Radon from Department of Energy Facilities,” §61.92.

ARES Corporation. 2005. "Seismic/Structural Scoping Study for the Zero Power Physics Reactor.” ARES Report 0527101.01-001.

ARES Corporation. 2006. "Structural Analysis of the MFC Building 775 Vault/Workroom Structure." W7750-0151-ES.

DOE. 2012. "Nonreactor Nuclear Safety Design Guide for use with DOE O 420.1C, Facility Safety.” DOE G 420.1-1A, U.S. Department of Energy.

DOE. 2018. “Facility Safety.” DOE O 420.1C, Ch. 2, U.S. Department of Energy.

DOE-ID. 2016a. “Idaho National Laboratory - Site Environmental Report.” DOE/ID-12082(15), U.S. Department of Energy Idaho Operations Office.

DOE-ID. 2016b. “Idaho National Laboratory Cultural Resource Management Plan.” DOE/ID-10997, Revision 6, U.S. Department of Energy Idaho Operations Office.

Dolphyn, B., M. Mudlock, and S. Bolourchi, “005BPDolphyn-L-191931.00 - MFC-776, ZPPR Reactor Cell Seismic Structural Scoping Study.” March 19, 2020.

EC. 2018. "Expanded Use of the Multipurpose Haul Road at the Idaho National Laboratory.” INL-18045, Regulatory \& Monitoring Services.

EPRI. 2002. "Siting Guide: Site Selection and Evaluation Criteria for an Early Site Permit Application.” Mar 21, 2002.

Evans, M., M. Mudlock, and S. Bolourchi, “002MAEvans-L-191931.00 - CPP-691, FPR Facility Seismic Structural Scoping Study.” January 29, 2020.

Evans, M., M. Mudlock, and S. Bolourchi, “004MAEvans-L-191931.00 - MFC-775 ZPPR, Vault/Workroom Seismic Structural Scoping Study.” March 19, 2020.

INL. 2011. “MFC Flood Control Diversion Dam Evaluation.” TEV-1368, Rev. 0.

INL. 2014. “Zero Power Physics Reactor Facility.” MFC00075, Rev. 1, MFC Nuclear Operations Training.

INL. 2016a. "Idaho National Laboratory Comprehensive Land Use and Environmental Stewardship Report.” INL/EXT-05-00726, Rev. 3.

INL. 2016b. "SSHAC Level 1 Probabilistic Seismic Hazard Analysis for the Idaho National Laboratory." INL/EXT-15-36682, Revision 2, Battelle Energy Alliance External Report.

INL. 2019a. "Work Plan for the Site-wide SSHAC Level 3 Probabilistic Seismic Hazard Analysis at INL.” INL/EXT-18-52101, Revision 1.

INL. 2019b. “2020 Campus Master Plan.” INL/INT-17-43395.

INL. 2019c. “MFC New Nuclear Site Development.” INL/EXT-19-55457.

Irving, J., email conversation with A. Conner, May 2, 2019. 
Kjelstrom, L.C. and C. Berenbrock. 1996. "Estimated 100-Year Peak Flows and Flow Volumes in the Big Lost River and Birch Creek at the Idaho National Engineering Laboratory, Idaho.” Water Resources Investigations Report 96- 4163, U.S. Geological Survey.

Kropp, G., email conversation with C. Richins, J. Sturm, and G. Griffith, February 13, 2020.

McCarthy, E., M. Mudlock, and S. Bolourchi. "003ERMcCarthy-L-191931.00 - SPERT IV Area, Power Burst Facility 613, Seismic Structural Scoping Study.”

NRC. 2014. “General Site Suitability Criteria for Nuclear Power Stations.” NRC ML12188A053, RG 4.7, Rev. 3, Regulatory Guide.

Office of Nuclear Energy. 2019. "Energy Department Launches New Demonstration Center for Advanced Nuclear Technologies.” https://www.energy.gov/ne/articles/energy-department-launches-newdemonstration-center-advanced-nuclear-technologies.

Payne, S., email conversation with A. Conner, November 12, 2019.

Payne, S., email conversation with A. Conner, January 14, 2020.

Roy, C.H., M. Mudlock, and S. Bolourchi, “001CHRoy-L-191931.00 - MFC-767, EBR-II Seismic Structural Scoping Study.” January 29, 2020.

USGS. 2006. “Quaternary Fault and Fold Database for the United States.” Accessed July 6, 2007. http//earthquakes.usgs.gov/regional/qfaults/.

Verdoorn, M., email conversation with A. Conner, March 18, 2020. 
Page intentionally left blank 


\section{Appendix A \\ Candidate Site Descriptions and Scoring Explanations}


Microreactor Candidate Site Descriptions and Scoring Explanations - Existing Buildings

\begin{tabular}{|c|l|l|l|l|l|l|l|}
\hline & & & & & & & \\
Location & Existing Building & Score & Flooding/Ponding - A & Score & Cooling Water - B & Score & Critical Habitat - C \\
\hline 1 & CPP-691 (FPR) & 10 & Outside of flooding area & 5 & $\begin{array}{l}\text { Existing wells in CERCLA } \\
\text { sites }\end{array}$ & 10 & $\begin{array}{l}\text { Outside of Sagebrush } \\
\text { Habitat; Outside of } \\
\text { conservation areas and } \\
\text { away from active leks }\end{array}$ \\
\hline 2 & MFC-767 (EBR-II) & 10 & Outside of flooding area & 10 & Existing wells & 10 & $\begin{array}{l}\text { Outside of Sagebrush } \\
\text { Habitat; Outside of } \\
\text { conservation areas and } \\
\text { away from active leks }\end{array}$ \\
\hline 3 & $\begin{array}{l}\text { MFC-775 (ZPPR } \\
\text { Workroom)/ MFC- } \\
776 \text { (ZPPR Reactor } \\
\text { Cell) }\end{array}$ & 10 & Outside of flooding area & 10 & $\begin{array}{l}\text { Existing wells } \\
\text { Habitat; Outside of } \\
\text { conservation areas and } \\
\text { away from active leks }\end{array}$ \\
\hline 5 & PBF-613 & 10 & Outside of flooding area & 10 & Existing wells & 10 & $\begin{array}{l}\text { Outside of conservation } \\
\text { areas and away from } \\
\text { active leks }\end{array}$ \\
\hline
\end{tabular}

Microreactor Candidate Site Descriptions and Scoring Explanations - Existing Buildings (continued)

\begin{tabular}{|c|l|l|l|l|l|l|l|}
\hline Location & Existing Building & Score & Predictive Archaeology Zones - D & Score & Existing Programs - E & Score & Security - F \\
\hline 1 & CPP-691 (FPR) & 10 & No impact & 10 & $\begin{array}{l}\text { facility managed by DOE } \\
\text { EM Program (Fluor); } \\
\text { existing program operating } \\
\text { within building is planned } \\
\text { to be complete in 2-3 } \\
\text { YEARS }\end{array}$ & $\begin{array}{l}\text { fectside existing INTEC } \\
\text { facility PIDAS }\end{array}$ \\
\hline 2 & MFC-767 (EBR-II) & 10 & No impact & $\begin{array}{l}\text { No existing program } \\
\text { within building }\end{array}$ & 10 & Inside MFC facility PIDAS \\
\hline 3 & $\begin{array}{l}\text { MFC-775 (ZPPR } \\
\text { Workroom)/ MFC- } \\
776 \text { (ZPPR Reactor } \\
\text { Cell) }\end{array}$ & 10 & No impact & $\begin{array}{l}\text { ZPPR will have to be } \\
\text { relocated }\end{array}$ & 10 & Inside ZPPR PIDAS \\
\hline 5 & PBF-613 & 5 & $\begin{array}{l}\text { Highly sensitive area for cultural } \\
\text { impacts if microreactor } \\
\text { operations requires an } \\
\text { expansion of facilities off the } \\
\text { existing asphalt }\end{array}$ & 1 & $\begin{array}{l}\text { Inside critical mission area; } \\
\text { highly utilized by other } \\
\text { programs }\end{array}$ & Within security controls \\
\hline
\end{tabular}

\section{Microreactor Candidate Site Descriptions and Scoring Explanations - Existing Buildings (continued)}

\begin{tabular}{|c|c|c|c|c|c|c|c|}
\hline Location & Existing Building & Score & $\begin{array}{l}\text { Distance from Transportation } \\
\text { Routes - G }\end{array}$ & Score & $\begin{array}{l}\text { Distance to Transmission } \\
\text { Lines - H }\end{array}$ & Score & $\begin{array}{l}\text { Land Use Planning Zones - } \\
\text { I }\end{array}$ \\
\hline 1 & CPP-691 (FPR) & 10 & $\begin{array}{l}\text { Near existing high quality roads; } \\
\text { INL rail line runs adjacent to } \\
\text { building }\end{array}$ & 10 & $\begin{array}{l}\text { Near transmission lines } \\
\text { and existing infrastructure; } \\
\text { utilities are run up to the } \\
\text { building }\end{array}$ & 10 & $\begin{array}{l}\text { Within appropriate } \\
\text { planning zones }\end{array}$ \\
\hline 2 & MFC-767 (EBR-II) & 10 & Near existing high quality roads & 10 & $\begin{array}{l}\text { Near transmission lines } \\
\text { and existing infrastructure } \\
\text { and update utility corridor } \\
\text { along the western and } \\
\text { northern perimeter of MFC }\end{array}$ & 10 & $\begin{array}{l}\text { Within appropriate } \\
\text { planning zones }\end{array}$ \\
\hline 3 & $\begin{array}{l}\text { MFC-775 (ZPPR } \\
\text { Workroom)/ MFC- } \\
776 \text { (ZPPR Reactor } \\
\text { Cell) }\end{array}$ & 10 & Near existing high quality roads & 10 & $\begin{array}{l}\text { Near transmission lines } \\
\text { and existing infrastructure; } \\
\text { working on updating utility } \\
\text { corridor on east side of } \\
\text { MFC }\end{array}$ & 10 & $\begin{array}{l}\text { Within appropriate } \\
\text { planning zones }\end{array}$ \\
\hline 5 & PBF-613 & 10 & Near existing high quality roads & 10 & $\begin{array}{l}\text { Next to substation and } \\
\text { transmission lines and } \\
\text { within existing } \\
\text { infrastructure }\end{array}$ & 10 & $\begin{array}{l}\text { Within appropriate } \\
\text { planning zones }\end{array}$ \\
\hline
\end{tabular}


Microreactor Candidate Site Descriptions and Scoring Explanations - Existing Buildings (continued)

\begin{tabular}{|c|c|c|c|c|c|c|}
\hline Location & Existing Building & Score & $\begin{array}{l}\text { Updated Seismic Hazard Analysis } \\
\text { and Site-Characterization Data - J }\end{array}$ & Score & $\begin{array}{l}\text { Proximity to Faults and } \\
\text { Building on Soil Sites - K }\end{array}$ & Additional Comments \\
\hline 1 & CPP-691 (FPR) & 10 & $\begin{array}{l}\text { Seismic Hazard Analysis and Site- } \\
\text { Characterization Data available } \\
\text { for INTEC facility; additional } \\
\text { seismic structural evaluation } \\
\text { completed in January } 2020 \text { found } \\
\text { building to be "Robust" meaning } \\
\text { it would probably withstand a } \\
\text { Performance Category 3 (PC-3) } \\
\text { event }\end{array}$ & 10 & Not near faults & Contains a 50 ton overhead crane \\
\hline 2 & MFC-767 (EBR-II) & 10 & $\begin{array}{l}\text { Seismic Hazard Analysis and Site- } \\
\text { Characterization Data available } \\
\text { for MFC facility; additional } \\
\text { seismic structural evaluation } \\
\text { completed in January } 2020 \text { found } \\
\text { building to be "Robust" meaning } \\
\text { it would probably withstand a PC } \\
\text { 3 event }\end{array}$ & 10 & Not near faults & \\
\hline 3 & $\begin{array}{l}\text { MFC-775 (ZPPR } \\
\text { Workroom)/ MFC- } \\
776 \text { (ZPPR Reactor } \\
\text { Cell) }\end{array}$ & 10 & $\begin{array}{l}\text { Seismic Hazard Analysis and Site- } \\
\text { Characterization Data available } \\
\text { for MFC facility; additional } \\
\text { seismic structural evaluation } \\
\text { pending }\end{array}$ & 10 & Not near faults & \\
\hline 5 & PBF-613 & 0 & \begin{tabular}{|l|} 
Site characterization data not \\
available for PBF-613; additional \\
seismic structural evaluation \\
completed in January 2020 found \\
building to be "Pretty Good" \\
meaning it may withstand a PC-3 \\
seismic event if detailed \\
calculations are performed but \\
would most likely withstand a \\
PC-2 event
\end{tabular} & 10 & Not near faults & $\begin{array}{l}\text { Standard operating utilities exist } \\
\text { within the building; includes an } \\
\text { overhead crane }\end{array}$ \\
\hline
\end{tabular}


Microreactor Candidate Site Descriptions and Scoring Explanations - Previously Developed Sites

\begin{tabular}{|c|l|l|l|l|l|l|l|}
\hline & & & & & & & \\
Location & Site Description & Score & Flooding/Ponding - A & Score & Cooling Water - B & Score & Critical Habitat - C \\
\hline 6 & CFA - Western Site & 10 & Outside of flooding area & 10 & Existing wells & 10 & $\begin{array}{l}\text { Outside of conservation areas } \\
\text { and away from active leks }\end{array}$ \\
\hline 32 & CFA - Eastern Site & 10 & Outside of flooding area & 10 & Existing wells & 10 & $\begin{array}{l}\text { Outside of conservation areas } \\
\text { and away from active leks }\end{array}$ \\
\hline
\end{tabular}

Microreactor Candidate Site Descriptions and Scoring Explanations - Previously Developed Sites (continued)

\begin{tabular}{|c|l|l|l|l|l|l|l|}
\hline Location & Site Description & Score & Predictive Archaeology Zones - D & Score & Existing Programs - E & Score & Security - F \\
\hline 6 & CFA - Western Site & 10 & $\begin{array}{l}\text { Previously disturbed area; Low } \\
\text { probability of unearthing } \\
\text { unknown cultural artifacts }\end{array}$ & 10 & No conflicts & 5 & $\begin{array}{l}\text { No additional security control } \\
\text { beyond main gate entrance }\end{array}$ \\
\hline 32 & CFA - Eastern Site & 10 & $\begin{array}{l}\text { Previously disturbed area; Low } \\
\text { probability of unearthing } \\
\text { unknown cultural artifacts }\end{array}$ & 10 & No conflicts & 5 & $\begin{array}{l}\text { No additional security control } \\
\text { beyond main gate entrance }\end{array}$ \\
\hline
\end{tabular}

Microreactor Candidate Site Descriptions and Scoring Explanations - Previously Developed Sites (continued)

\begin{tabular}{|c|l|l|l|l|l|l|}
\hline Location & Site Description & Score & $\begin{array}{l}\text { Distance from Transportation } \\
\text { Routes - G }\end{array}$ & Score & $\begin{array}{l}\text { Distance to Transmission } \\
\text { Lines - H }\end{array}$ & Score \\
\hline 6 & CFA - Western Site & 10 & Near existing high quality roads & 10 & $\begin{array}{l}\text { Near transmission lines } \\
\text { and existing infrastructure }\end{array}$ & $\begin{array}{l}10 \\
\text { Lithin appropriate planning } \\
\text { zones }\end{array}$ \\
\hline 32 & CFA - Eastern Site & 10 & Near existing high quality roads & 10 & $\begin{array}{l}\text { Near transmission lines } \\
\text { and existing infrastructure }\end{array}$ & $\begin{array}{l}\text { Within appropriate planning } \\
\text { zones }\end{array}$ \\
\hline
\end{tabular}

Microreactor Candidate Site Descriptions and Scoring Explanations - Previously Developed Sites (continued)

\begin{tabular}{|c|c|c|c|c|c|c|}
\hline Location & Site Description & Score & $\begin{array}{l}\text { Updated Seismic Hazard Analysis } \\
\text { and Site-Characterization Data - }\end{array}$ & Score & $\begin{array}{l}\text { Proximity to Faults and } \\
\text { Building on Soil Sites - K }\end{array}$ & Additional Comments \\
\hline 6 & CFA - Western Site & 0 & No data for CFA & 5 & $\begin{array}{l}\text { Soil over basalt, not rock; } \\
\text { soil sites generally amplify } \\
\text { ground motions by factors } \\
\text { of } 1.5 \text { to } 2\end{array}$ & \\
\hline 32 & CFA - Eastern Site & 0 & No data for CFA & 5 & $\mid \begin{array}{l}\text { Soil over basalt, not rock; } \\
\text { soil sites generally amplify } \\
\text { ground motions by factors } \\
\text { of } 1.5 \text { to } 2\end{array}$ & \\
\hline
\end{tabular}


Microreactor Candidate Site Descriptions and Scoring Explanations - Undeveloped Sites

\begin{tabular}{|c|c|c|c|c|c|c|c|c|c|c|c|c|c|}
\hline Location & Existing Building & Score & Flooding/Ponding - A & Score & Cooling Water - B & Score & Critical Habitat - C & Score & \begin{tabular}{|l} 
Predictive \\
Archaeology Zones - D
\end{tabular} & Score & Existing Programs - E & Score & Security - F \\
\hline 8 & $\begin{array}{l}\text { ATR Complex- } \\
\text { Outside Security } \\
\text { Fence }\end{array}$ & 5 & $\begin{array}{l}\text { drainage area, high degree of } \\
\text { flooding }\end{array}$ & 10 & Existing wells & 10 & $\begin{array}{l}\text { Outside of Sagebrush } \\
\text { Habitat; Outside of } \\
\text { conservation areas and } \\
\text { away from active leks }\end{array}$ & 10 & $\begin{array}{l}\text { Need to survey ditch, } \\
\text { minimal chance of } \\
\text { finding cultural } \\
\text { artifacts }\end{array}$ & 10 & $\begin{array}{l}\text { new parking lot on } \\
\text { westside, new access } \\
\text { to ATRC, moving site a } \\
\text { little south would be } \\
\text { will eliminate } \\
\text { conflicts }\end{array}$ & 5 & $\begin{array}{l}\text { Outside ATR Complex } \\
\text { facility PIDAS }\end{array}$ \\
\hline 9 & MFC - Western Sites & 10 & Outside of flooding area & 10 & Existing wells & 10 & $\begin{array}{l}\text { Outside of conservation } \\
\text { areas and away from } \\
\text { active leks }\end{array}$ & 10 & $\begin{array}{l}\text { Low probability of } \\
\text { unearthing unknown } \\
\text { cultural artifacts }\end{array}$ & 5 & \begin{tabular}{|l|} 
Need to locate site \\
out of TREAT \\
boundary/buffer zone
\end{tabular} & 5 & $\begin{array}{l}\text { Outside MFC facility } \\
\text { PIDAS }\end{array}$ \\
\hline 10 & MFC - North Sites & 5 & $\begin{array}{l}\text { drainage area, high degree of } \\
\text { flooding }\end{array}$ & 10 & Existing wells & 10 & $\begin{array}{l}\text { Outside of conservation } \\
\text { areas and away from } \\
\text { active leks }\end{array}$ & 10 & \begin{tabular}{|l|} 
Low probability of \\
unearthing unknown \\
cultural artifacts
\end{tabular} & 10 & No impacts & 5 & $\begin{array}{l}\text { Outside MFC facility } \\
\text { PIDAS }\end{array}$ \\
\hline 11 & MFC - East Sites & 10 & Outside of flooding area & 10 & Existing wells & 10 & $\begin{array}{l}\text { Outside of conservation } \\
\text { areas and away from } \\
\text { active leks }\end{array}$ & 10 & $\begin{array}{l}\text { Low probability of } \\
\text { unearthing unknown } \\
\text { cultural artifacts }\end{array}$ & 5 & $\begin{array}{l}\text { Need to ensure site is } \\
\text { located beyond the } \\
500 \text { yard buffer zone } \\
\text { around the HCI tank } \\
\text { and ZIRCEX facility }\end{array}$ & 5 & $\begin{array}{l}\text { Outside MFC facility } \\
\text { PIDAS }\end{array}$ \\
\hline 12 & \begin{tabular}{|l|} 
on the west side of \\
inL Site
\end{tabular} & 1 & $\begin{array}{l}\text { Located near designated } \\
\text { wetlands area }\end{array}$ & 10 & Existing wells & 10 & $\begin{array}{l}\text { Inside Conservation Area } \\
\text { but manageable }\end{array}$ & 1 (Cultur & $\begin{array}{l}\text { Need to survey. In } \\
\text { proximity of a tribally } \\
\text { sensitive site. }\end{array}$ & 10 & No impacts & 1 & $\begin{array}{l}\text { Need to build all new } \\
\text { security controls }\end{array}$ \\
\hline 13 & $\begin{array}{l}\text { on the west side of } \\
\text { INL Site }\end{array}$ & 5 & Previously observed flooding & 10 & Existing wells & 10 & $\begin{array}{l}\text { Inside Conservation Area } \\
\text { but manageable }\end{array}$ & 0 (CRMO & $\begin{array}{l}\text { Potential significant } \\
\text { cultural issues; need } \\
\text { to survey. In direct } \\
\text { proximity of a tribally } \\
\text { sensitive site. }\end{array}$ & 10 & No impacts & 1 & $\begin{array}{l}\text { Need to build all new } \\
\text { security controls }\end{array}$ \\
\hline 15 & $\begin{array}{l}\text { in northern corner } \\
\text { of INL Site }\end{array}$ & 10 & No flooding issues & 5 & & 10 & $\begin{array}{l}\text { Inside Conservation Area } \\
\text { but manageable }\end{array}$ & 5 & \begin{tabular}{|l|} 
Potential significant \\
cultural issues; need \\
to survey
\end{tabular} & 10 & No impacts & 1 & $\begin{array}{l}\text { Need to build all new } \\
\text { security controls }\end{array}$ \\
\hline 16 & $\begin{array}{l}\text { in northern corner } \\
\text { of INL Site }\end{array}$ & 10 & No flooding issues & 5 & & 10 & $\begin{array}{l}\text { Outside of conservation } \\
\text { areas }\end{array}$ & 5 & \begin{tabular}{|l|}
$\begin{array}{l}\text { Potential significant } \\
\text { cultural issues; need } \\
\text { to survey }\end{array}$ \\
\end{tabular} & 10 & No impacts & 1 & $\begin{array}{l}\text { Need to build all new } \\
\text { security controls }\end{array}$ \\
\hline $\begin{array}{c}17 \\
\text { Eliminated } \\
\text { upon } \\
\text { further } \\
\text { review by } \\
\text { SME due to } \\
\text { 100-yr Birch } \\
\text { Creek } \\
\text { floodplain } \\
\end{array}$ & INL Site, above SMC & 5 & ding & 5 & $\begin{array}{l}\text { Suggested Change: Drilling } \\
\text { a well would be required } \\
\text { for cooling water. This }\end{array}$ & & $\begin{array}{l}\text { Outside of c } \\
\text { areas }\end{array}$ & 5 & $\begin{array}{l}\text { Potential significant } \\
\text { cultural issues; need } \\
\text { to survey }\end{array}$ & 10 & & 1 & $\begin{array}{l}\text { Need to build all } r \\
\text { security controls }\end{array}$ \\
\hline 18 & $\begin{array}{l}\text { in northern corner } \\
\text { of INL Site }\end{array}$ & 10 & No flooding issues & 5 & $\begin{array}{l}\text { applies for all locations } \\
\text { below. We have well data } \\
\text { in many of these areas. }\end{array}$ & 10 & $\begin{array}{l}\text { Outside of conservation } \\
\text { areas }\end{array}$ & 5 & \begin{tabular}{|l|}
$\begin{array}{l}\text { Potential significant } \\
\text { cultural issues; need } \\
\text { to survey }\end{array}$ \\
\end{tabular} & 10 & No impacts & 1 & $\begin{array}{l}\text { Need to build all new } \\
\text { security controls }\end{array}$ \\
\hline 19 & $\begin{array}{l}\text { in northern area of } \\
\text { INL Site, along Hwy } \\
33\end{array}$ & 10 & No flooding issues & 5 & $\begin{array}{l}\text { More would be needed on } \\
\text { production requirements. } \\
\text { Note: cost to put in well }\end{array}$ & 10 & $\begin{array}{l}\text { Outside of conservation } \\
\text { areas }\end{array}$ & 1 & $\begin{array}{l}\text { Highly sensitive area } \\
\text { for cultural impacts }\end{array}$ & 10 & No impacts & 1 & $\begin{array}{l}\text { Need to build all new } \\
\text { security controls }\end{array}$ \\
\hline 21 & \begin{tabular}{|l|} 
in northern area of \\
INL Site, along Hwy \\
22
\end{tabular} & 10 & No flooding issues & 5 & $\begin{array}{l}\text { along northern end of INL } \\
\text { is less, where depth to } \\
\text { water is in the } 200 \text { to } 300 \mathrm{ft}\end{array}$ & 5 & $\begin{array}{l}\text { Sagebrush Habitat; } \\
\text { no leks }\end{array}$ & 5 & \begin{tabular}{|l|}
$\begin{array}{l}\text { Potential significant } \\
\text { cultural issues; need } \\
\text { to survey }\end{array}$ \\
\end{tabular} & 10 & No impacts & 1 & $\begin{array}{l}\text { Need to build all new } \\
\text { security controls }\end{array}$ \\
\hline 25 & \begin{tabular}{|l|} 
located fairly central \\
within INL Site, \\
above MFC
\end{tabular} & 10 & No flooding issues & 5 & $\begin{array}{l}\text { range. Cost to put a well } \\
\text { along the southern end is } \\
\text { higher, where depth to }\end{array}$ & 10 & $\begin{array}{l}\text { Outside of conservation } \\
\text { areas }\end{array}$ & 5 & \begin{tabular}{|l|}
$\begin{array}{l}\text { Potential significant } \\
\text { cultural issues; need } \\
\text { to survey }\end{array}$ \\
\end{tabular} & 1 & $\begin{array}{l}\text { Impacts to explosive } \\
\text { test range }\end{array}$ & 1 & $\begin{array}{l}\text { Need to build all new } \\
\text { security controls }\end{array}$ \\
\hline 26 & $\begin{array}{l}\text { located between } \\
\text { CITRC and MFC }\end{array}$ & 10 & No flooding issues & 5 & $\begin{array}{l}\text { water is in the } 600 \text { to } 700 \mathrm{ft} \\
\text { range. (Brian V. Twining } \\
\text { revised } 1 / 27 / 2020 \text { ) }\end{array}$ & 5 & Sagebrush Habitat & 5 & \begin{tabular}{|l|}
$\begin{array}{l}\text { Potential significant } \\
\text { cultural issues; need } \\
\text { to survey }\end{array}$ \\
\end{tabular} & 1 & $\begin{array}{l}\text { Impacts to explosive } \\
\text { test range }\end{array}$ & 1 & $\begin{array}{l}\text { Need to build all new } \\
\text { security controls }\end{array}$ \\
\hline 28 & $\begin{array}{l}\text { located in southern } \\
\text { area of INL Site, } \\
\text { south of Hwy 20/26 }\end{array}$ & 10 & No flooding issues & 5 & & 1 & $\begin{array}{l}\text { Sagebrush Habitat; } \\
\text { close to lek }\end{array}$ & 1 & \begin{tabular}{|l|}
$\begin{array}{l}\text { Highly sensitive area } \\
\text { for cultural impacts }\end{array}$ \\
\end{tabular} & 10 & No impacts & 1 & $\begin{array}{l}\text { Need to build all new } \\
\text { security controls }\end{array}$ \\
\hline 29 & \begin{tabular}{|l|} 
located on east side \\
of INL Site along \\
Hwy 20/26
\end{tabular} & 10 & No flooding issues & 5 & & 5 & Sagebrush Habitat & 5 & \begin{tabular}{|l|}
$\begin{array}{l}\text { Potential significant } \\
\text { cultural issues; need } \\
\text { to survey }\end{array}$ \\
\end{tabular} & 10 & No impacts & 1 & $\begin{array}{l}\text { Need to build all new } \\
\text { security controls }\end{array}$ \\
\hline 30 & $\begin{array}{l}\text { located on west side } \\
\text { of INL Site }\end{array}$ & 10 & No flooding issues & 5 & & 5 & Sagebrush Habitat & 5 & \begin{tabular}{|l|}
$\begin{array}{l}\text { Potential significant } \\
\text { cultural issues; need } \\
\text { to survey }\end{array}$ \\
\end{tabular} & 5 & \begin{tabular}{|l|} 
Area proposed for Full \\
Scale Test Range \\
(FSTR)
\end{tabular} & 1 & $\begin{array}{l}\text { Need to build all new } \\
\text { security controls }\end{array}$ \\
\hline 31 & $\begin{array}{l}\text { located south of } \\
\text { MFC, near Hwy } 20\end{array}$ & 10 & No flooding issues & 5 & & 5 & Sagebrush Habitat & 10 & \begin{tabular}{|l|}
$\begin{array}{l}\text { Potential significant } \\
\text { cultural issues; need } \\
\text { to survey }\end{array}$ \\
\end{tabular} & 10 & No impacts & 1 & $\begin{array}{l}\text { Need to build all new } \\
\text { security controls }\end{array}$ \\
\hline
\end{tabular}


Microreactor Candidate Site Descriptions and Scoring Explanations - Undeveloped Sites (continued)

\begin{tabular}{|c|c|c|c|c|c|c|c|c|c|c|c|c|}
\hline Location & Existing Building & Score & \begin{tabular}{|l|} 
Distance from \\
Transportation Routes \\
G
\end{tabular} & Score & \begin{tabular}{|l|} 
Distance to \\
Transmission Lines - H \\
\end{tabular} & Score & $\begin{array}{l}\text { Land Use Planning } \\
\text { Zones - I }\end{array}$ & Score & $\begin{array}{l}\text { Updated Seismic Hazard } \\
\text { Analysis and Site- } \\
\text { Characterization Data - J }\end{array}$ & Score & $\begin{array}{l}\text { Proximity to Faults } \\
\text { and Building on Soil } \\
\text { Sites - K }\end{array}$ & Additional Comments \\
\hline 8 & $\begin{array}{l}\text { ATR Complex - } \\
\text { Outside Security } \\
\text { Fence }\end{array}$ & 10 & $\begin{array}{l}\text { Near existing high } \\
\text { quality roads }\end{array}$ & 10 & \begin{tabular}{|l} 
Near transmission \\
lines and existing \\
infrastructure
\end{tabular} & 10 & $\begin{array}{l}\text { Within appropriate } \\
\text { planning zones }\end{array}$ & 10 & $\begin{array}{l}\text { Seismic Hazard Analysis } \\
\text { and Site- } \\
\text { Characterization Data } \\
\text { available for ATR-C } \\
\text { facility area; data is } \\
\text { applicable within } 500 \\
\text { yards outside the fence }\end{array}$ & 5 & About 20 feet of soil & \\
\hline 9 & MFC - Western Sites & 10 & $\begin{array}{l}\text { Near existing high } \\
\text { quality roads }\end{array}$ & 10 & \begin{tabular}{|l} 
Near transmission \\
lines and existing \\
infrastructure
\end{tabular} & 10 & $\begin{array}{l}\text { Within appropriate } \\
\text { planning zones }\end{array}$ & 10 & $\begin{array}{l}\text { Seismic Hazard Analysis } \\
\text { and Site- } \\
\text { Characterization Data } \\
\text { available for MFC } \\
\text { facility; data is } \\
\text { applicable withing } 500 \\
\text { yards outside of fence } \\
\end{array}$ & 10 & Not near faults & \\
\hline 10 & MFC - North Sites & 10 & $\begin{array}{l}\text { Near existing high } \\
\text { quality roads }\end{array}$ & 10 & $\begin{array}{l}\text { Near transmission } \\
\text { lines and existing } \\
\text { infrastructure }\end{array}$ & 10 & $\begin{array}{l}\text { Within appropriate } \\
\text { planning zones }\end{array}$ & 10 & $\begin{array}{l}\text { Seismic Hazard Analysis } \\
\text { and Site- } \\
\text { Characterization Data } \\
\text { available for MFC } \\
\text { facility; data is } \\
\text { applicable withing } 500 \\
\text { yards outside of fence }\end{array}$ & 10 & Not near faults & \\
\hline 11 & MFC - East Sites & 10 & $\begin{array}{l}\text { Near existing high } \\
\text { quality roads }\end{array}$ & 10 & $\begin{array}{l}\text { Near transmission } \\
\text { lines and existing } \\
\text { infrastructure }\end{array}$ & 10 & \begin{tabular}{|l} 
Within appropriate \\
planning zones
\end{tabular} & 10 & $\begin{array}{l}\text { Seismic Hazard Analysis } \\
\text { and Site- } \\
\text { Characterization Data } \\
\text { available for MFC } \\
\text { facility; data is } \\
\text { applicable withing } 500 \\
\text { yards outside of fence }\end{array}$ & 10 & Not near faults & \\
\hline 12 & $\begin{array}{l}\text { on the west side of } \\
\text { INL Site }\end{array}$ & 1 & Not close to roads & 1 & \begin{tabular}{|l} 
Not close to \\
transmission lines
\end{tabular} & 1 & $\begin{array}{l}\text { Outside of planned } \\
\text { zones }\end{array}$ & 0 & No data available & 10 & Not near faults & \\
\hline 13 & $\begin{array}{l}\text { on the west side of } \\
\text { INL Site }\end{array}$ & 1 & Not close to roads & 1 & \begin{tabular}{|l|} 
Not close to \\
transmission lines
\end{tabular} & 1 & $\begin{array}{l}\text { Outside of planned } \\
\text { zones }\end{array}$ & 0 & No data available & 10 & Not near faults & \\
\hline 15 & $\begin{array}{l}\text { in northern corner } \\
\text { of INL Site }\end{array}$ & 5 & Not close to roads & 5 & $\begin{array}{l}\text { Transmission lines in } \\
\text { the area }\end{array}$ & 5 & $\begin{array}{l}\text { Outside of planned } \\
\text { zones }\end{array}$ & 0 & No data available & 10 & Not near faults & \\
\hline 16 & $\begin{array}{l}\text { in northern corner } \\
\text { of INL Site }\end{array}$ & 5 & $\begin{array}{l}\text { Relatively close to } \\
\text { highway }\end{array}$ & 1 & $\begin{array}{l}\text { Not close to } \\
\text { transmission lines }\end{array}$ & 5 & $\begin{array}{l}\text { Close to planned } \\
\text { zoning }\end{array}$ & 0 & No data available & 10 & Not near faults & \\
\hline $\begin{array}{c}17 \\
\text { Eliminated } \\
\text { upon } \\
\text { further } \\
\text { review by } \\
\text { SME due to } \\
\text { 100-yr Birch } \\
\text { Creek } \\
\text { floodplain }\end{array}$ & $\begin{array}{l}\text { in northern area of } \\
\text { INL Site, above SMC } \\
\end{array}$ & & Not close to roads & 1 & $\begin{array}{l}\text { Not close to } \\
\text { transmission lines }\end{array}$ & 5 & $\begin{array}{l}\text { Close to planned } \\
\text { zoning }\end{array}$ & 0 & No data available & 10 & Not near faults & \\
\hline 18 & $\begin{array}{l}\text { in northern corner } \\
\text { of INL Site }\end{array}$ & 5 & $\begin{array}{l}\text { Relatively close to } \\
\text { highway }\end{array}$ & 5 & $\begin{array}{l}\text { Relatively close to } \\
\text { transmission line }\end{array}$ & 5 & $\begin{array}{l}\text { Close to planned } \\
\text { zoning }\end{array}$ & 0 & No data available & 10 & Not near faults & \\
\hline 19 & $\begin{array}{l}\text { in northern area of } \\
\text { INL Site, along Hwy } \\
33\end{array}$ & 5 & $\begin{array}{l}\text { Relatively close to } \\
\text { highway }\end{array}$ & 5 & $\begin{array}{l}\text { Relatively close to } \\
\text { transmission line }\end{array}$ & 5 & $\begin{array}{l}\text { lose to planned } \\
\text { zoning }\end{array}$ & 0 & No data available & 5 & Deep soil layer & \\
\hline 21 & $\begin{array}{l}\text { in northern area of } \\
\text { INL Site, along Hwy } \\
22\end{array}$ & 5 & $\begin{array}{l}\text { Relatively close Hyw } \\
22\end{array}$ & 1 & \begin{tabular}{|l} 
Not close to \\
transmission lines
\end{tabular} & 1 & $\begin{array}{l}\text { Outside of planned } \\
\text { zones }\end{array}$ & 0 & No data available & 10 & Not near faults & \\
\hline 25 & $\begin{array}{l}\text { located fairly central } \\
\text { within INL Site, } \\
\text { above MFC }\end{array}$ & 1 & Not close to roads & 1 & $\begin{array}{l}\text { Not close to } \\
\text { transmission lines }\end{array}$ & 1 & $\begin{array}{l}\text { Outside of planned } \\
\text { zones }\end{array}$ & 0 & No data available & 10 & Not near faults & \\
\hline 26 & $\begin{array}{l}\text { located between } \\
\text { CITRC and MFC }\end{array}$ & 1 & Not close to roads & 1 & $\begin{array}{l}\text { Not close to } \\
\text { transmission lines }\end{array}$ & 10 & $\begin{array}{l}\text { Within appropriate } \\
\text { planning zones }\end{array}$ & 0 & No data available & 10 & Not near faults & \\
\hline 28 & $\begin{array}{l}\text { located in southern } \\
\text { area of INL Site, } \\
\text { south of Hwy 20/26 }\end{array}$ & 5 & $\begin{array}{l}\text { Relatively close to } \\
\text { highway; south of } \mathrm{Hwy} \\
20 \text { at intersection of } \\
\text { Hwy } 20 / 26\end{array}$ & 5 & $\begin{array}{l}\text { Relatively close to } \\
\text { transmission line }\end{array}$ & 10 & $\begin{array}{l}\text { Within appropriate } \\
\text { planning zones }\end{array}$ & 0 & No data available & 10 & Not near faults & \\
\hline 29 & $\begin{array}{l}\text { located on east side } \\
\text { of INL Site along } \\
\text { Hwy 20/26 }\end{array}$ & 5 & \begin{tabular}{|l} 
Relatively close to \\
Hwy 20/26
\end{tabular} & 5 & $\begin{array}{l}\text { Relatively close to } \\
\text { transmission line }\end{array}$ & 10 & $\begin{array}{l}\text { Within appropriate } \\
\text { planning zones }\end{array}$ & 0 & No data available & 5 & Close to fault & \\
\hline 30 & $\begin{array}{l}\text { located on west side } \\
\text { of INL Site }\end{array}$ & 1 & Not close to roads & 1 & \begin{tabular}{|l|} 
Not close to \\
transmission lines
\end{tabular} & 5 & $\begin{array}{l}\text { Close to planned } \\
\text { zoning }\end{array}$ & 0 & No data available & 10 & Not near faults & \\
\hline 31 & $\begin{array}{l}\text { located south of } \\
\text { MFC, near Hwy } 20 \\
\end{array}$ & 10 & $\begin{array}{l}\text { Close to Hyw } 20 \text { and } \\
\text { haul road }\end{array}$ & 5 & $\begin{array}{l}\text { Relatively close to } \\
\text { transmission line }\end{array}$ & 10 & $\begin{array}{l}\text { Within appropriate } \\
\text { planning zones }\end{array}$ & 0 & No data available & 10 & Not near faults & \\
\hline
\end{tabular}


Page intentionally left blank 


\section{Appendix B \\ SME Evaluation Meetings - Documentation}

\section{Microreactors Siting - Candidate Sites Evaluation}

Wednesday, January 15, 2020

8:00 Introductions

8:05 Project Overview

8:15 Review Go/No Go or "Must" Criteria and Initial Screening of Candidate Sites

8:35 Review List of "Want" Criteria and Modify, as needed

8:55 Conduct Paired Comparison of "Want" Criteria

9:25 Capture Technical Input on Candidate Sites and Assign Scores

10:45 Capture Final Comments and Wrap Up

10:55 Adjourn 


\section{Microreactors Siting - Candidate Sites Evaluation}

Thursday, January 23, 2020

12:30 Welcome

12:35 Review Results from January $15^{\text {th }}$ Meeting

12:45 Continue Capture Technical Input on Candidate Sites and Assign Scores

2:00 Review Ranked List of Candidate Sites and Discuss, as needed

2:15 Capture Final Comments and Wrap Up

2:25 Adjourn

Scoring Definitions for A-I:

$10=$ Candidate site meets criterion with minimal to no difficulty

5 = Candidate site meets criterion with some difficulty

$1=$ High degree of uncertainty as to whether the candidate site can meet criterion

$0=$ Candidate site cannot meet criterion

Scoring Definitions for $\mathrm{J}$ :

$10=$ Candidate site meets criterion with minimal to no difficulty

$5=\mathrm{N} / \mathrm{A}$

$1=\mathrm{N} / \mathrm{A}$

$0=$ Candidate site cannot meet criterion

Scoring Definitions for K:

$10=$ Low ground motions at candidate sites

$5=$ Intermediate ground motions at candidate sites

$1=\mathrm{N} / \mathrm{A}$

$0=$ High ground motions at candidate sites 


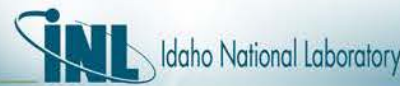

\section{Microreactors Siting - Candidate Sites Evaluation January 23, 2020}

Meeting Participants:

\begin{tabular}{|c|c|c|c|c|}
\hline $1 / 15 / 20$ & $1 / 23 / 20$ & NAME & EMAIL ADDRESS & ORGANIZATION \\
\hline $\bar{X}$ & $\bar{X}$ & Jeffrey Anderson & jeffrey.anderson@inl.gov & Physical Security \\
\hline $\bar{X}$ & & Jason Andrus & jason.andrus@inl.gov & $\begin{array}{l}\text { Adv Nuclear Facility } \\
\text { Safety Engineering }\end{array}$ \\
\hline$X$ & $X$ & Alison Conner & alison.conner@inl.gov & $\begin{array}{l}\text { Systems Analyses \& } \\
\text { Engineering }\end{array}$ \\
\hline & $\mathrm{X}$ & Reese Cook & reese.cook@inl.gov & Cultural Resources \\
\hline $\bar{X}$ & $\bar{X}$ & George Griffith & george.griffith@inl.gov & INL SMR RDD\&D \\
\hline $\mathrm{X}$ & & Louis Guillen & louis.guillen@inl.gov & Project Engineering \\
\hline $\bar{X}$ & & Helen Guymon & helen.guymon@in.gov & Project Management \\
\hline $\bar{X}$ & $\mathrm{X}$ & Kirt Hodges & kirt.hodges@inl.gov & Physical Security \\
\hline $\mathrm{X}$ & & Nicholas Holmer & nicholas.holmer@inl.gov & Cultural Resources \\
\hline $\mathrm{X}$ & $\mathrm{X}$ & Randy Lee & randy.lee@inl.gov & Campus Development \\
\hline $\bar{X}$ & $\bar{X}$ & Sal Mascarenas & salvador.mascarenas@inl.gov & Project Engineering \\
\hline $\bar{X}$ & $\bar{X}$ & Mike W. Patterson & mw.patterson@inl.gov & Nuclear Engineering \\
\hline $\bar{X}$ & $\mathrm{X}$ & Suzette Payne & suzette.payne@inl.gov & Geophysics Engineering \\
\hline $\bar{X}$ & $\bar{X}$ & Troy Reiss & troy.reiss@inl.gov & $\begin{array}{l}\text { Adv Nuclear Facility } \\
\text { Safety Engineering }\end{array}$ \\
\hline $\bar{X}$ & $\bar{X}$ & Wayne Ridgway & wayne.ridgway@inl.gov & Project Management \\
\hline $\bar{X}$ & $\bar{X}$ & Mary Scales English & mary.scalesenglish@inl.gov & Cultural Resources \\
\hline $\mathrm{X}$ & $\mathrm{X}$ & Tim Solle & timothy.solle@inl.gov & MFC ES\&S \\
\hline $\mathrm{X}$ & $\mathrm{X}$ & Brian Twining & btwining@usgs.gov & USGS \\
\hline $\mathrm{X}$ & & Mark Verdoom & mark.verdoom@inl.gov & Regulatory Compliance \\
\hline
\end{tabular}


Page intentionally left blank 


\section{Appendix C INL Site Maps}




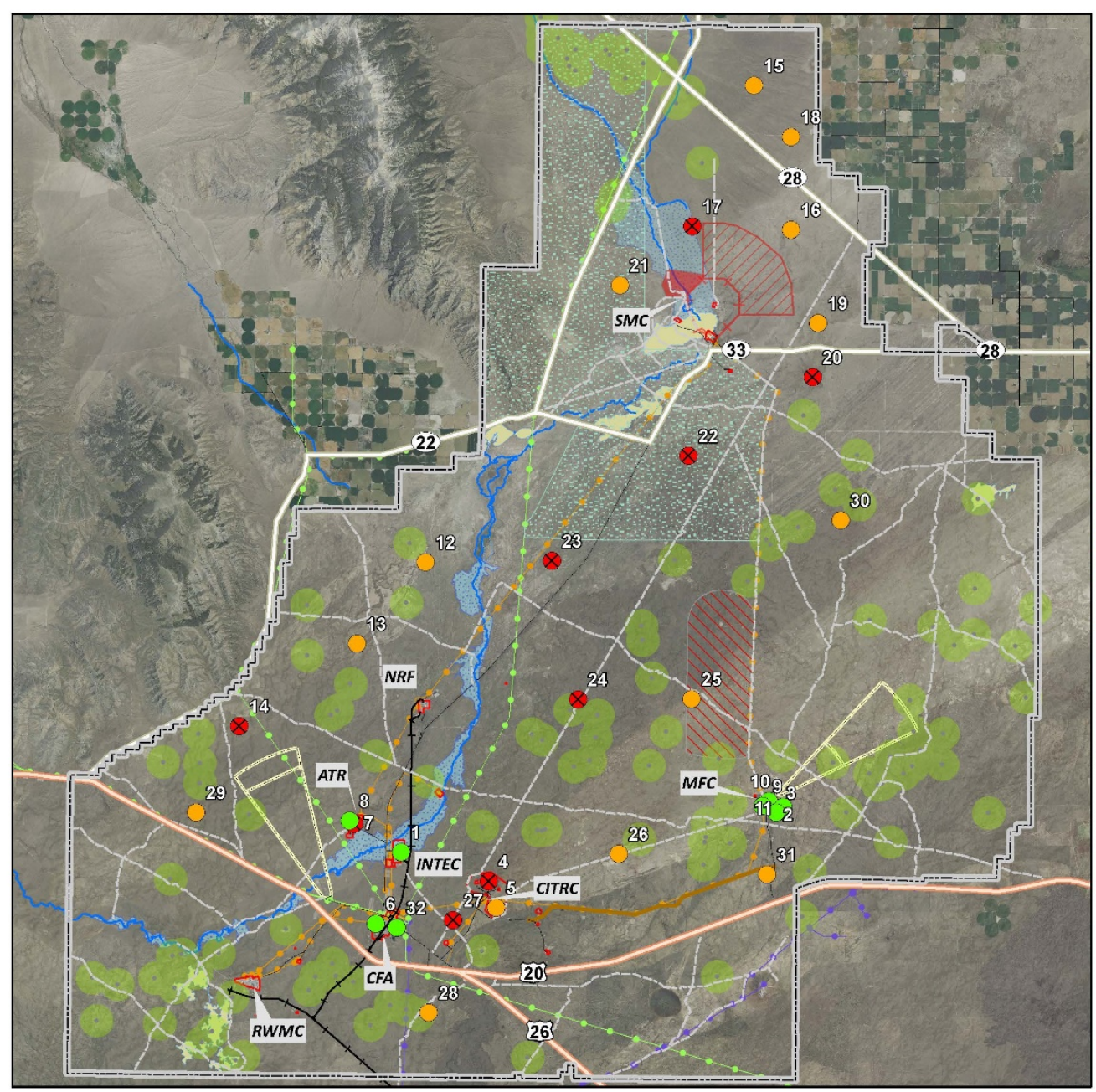

\section{Advanced Reactor Siting Evaluation Map}

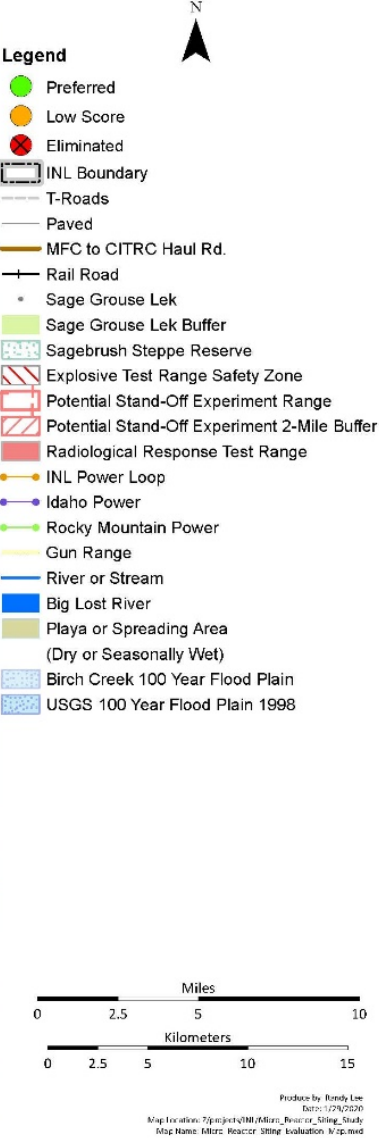




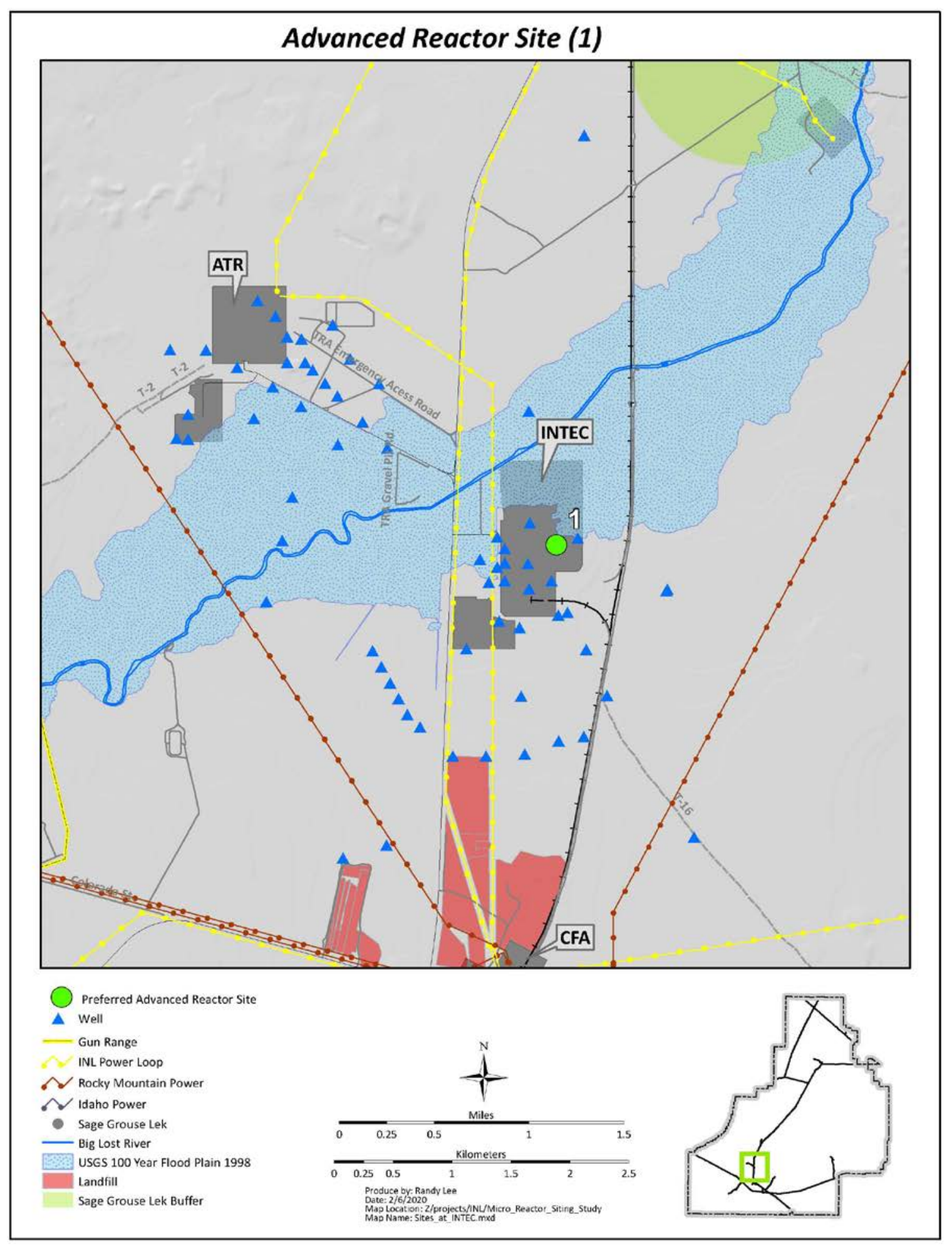




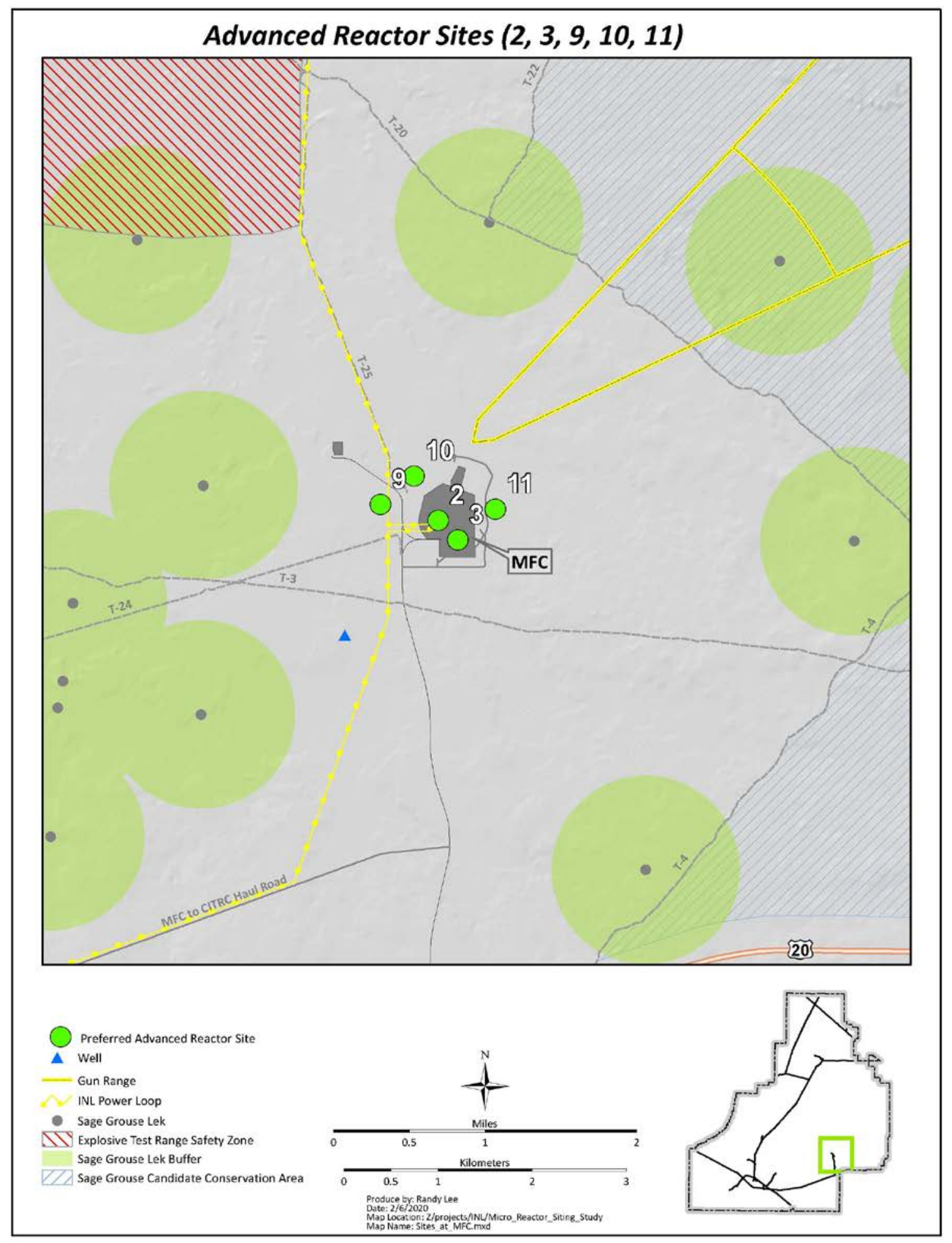




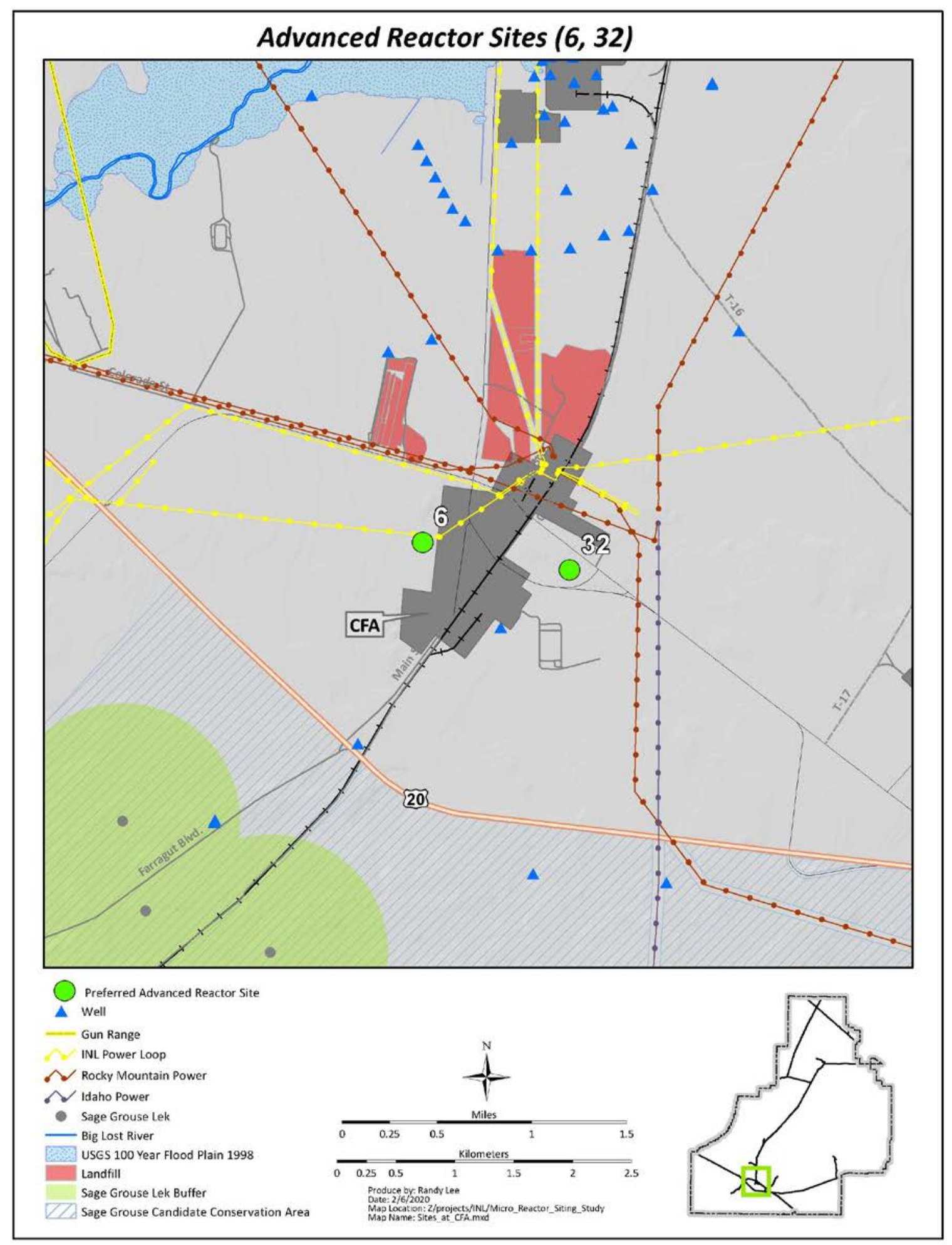




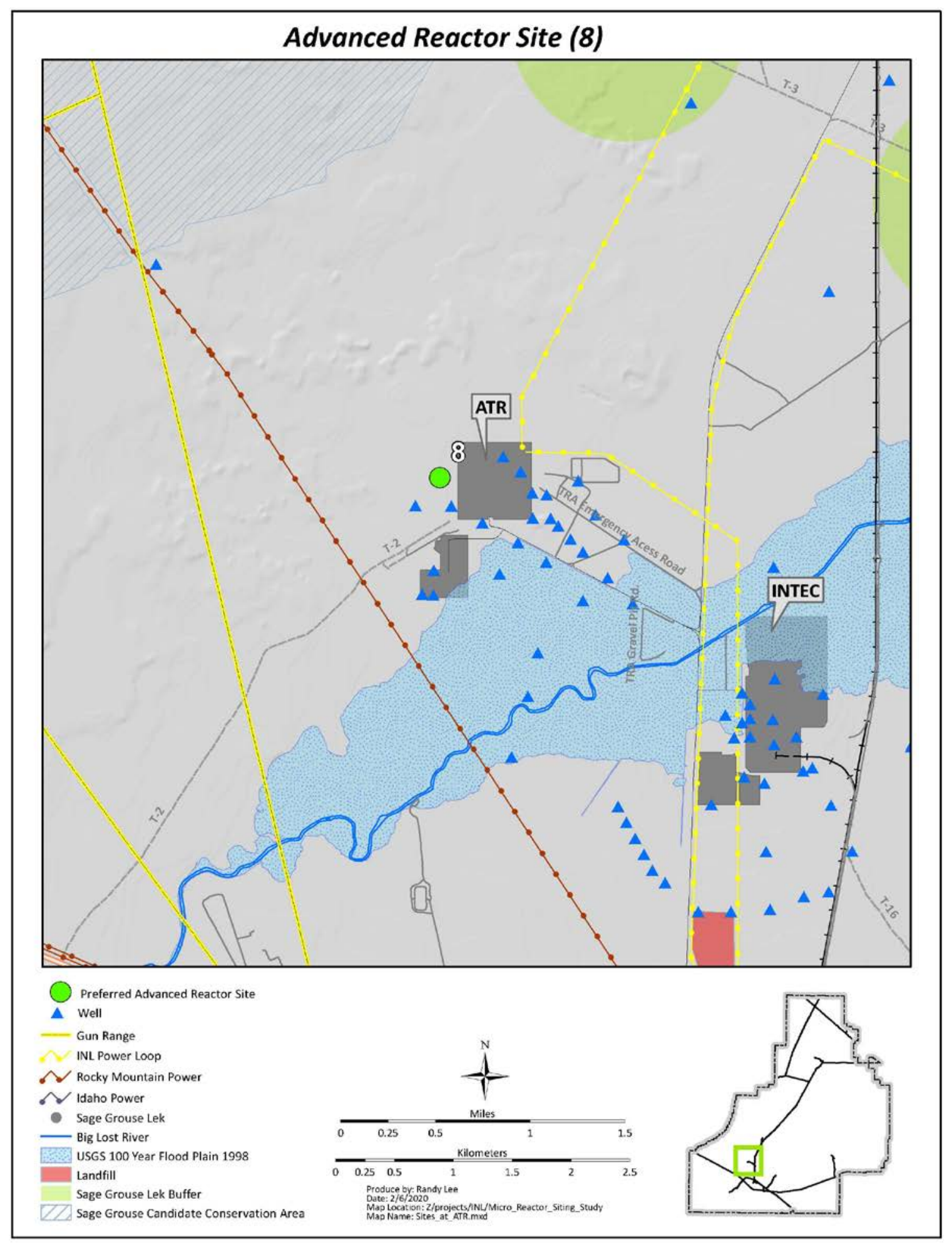


Page intentionally left blank 


\section{Appendix D \\ Summary Results of CAP88 at Site \#31}


MFC Sources for 2018 NESHAP

\begin{tabular}{|c|c|}
\hline MFC 704008 & \multirow{4}{*}{ TREAT } \\
\hline MFC 720007 & \\
\hline MFC 752004 & \\
\hline MFC 752 _. 005 & \\
\hline MFC 764 001 & \multirow[t]{16}{*}{ Main Stack } \\
\hline MFC $768 \_105$ & \\
\hline MFC_768_108 & \\
\hline MFC_774_026 & \\
\hline MFC_ 774_027 & \\
\hline MFC_774_028 & \\
\hline MFC $774 \quad 029$ & \\
\hline MFC 777002 & \\
\hline MFC 785018 & \\
\hline MFC_787_001 & \\
\hline MFC 792A 001 & \\
\hline MFC_793_001 & \\
\hline MFC_ 794002 & \\
\hline MFC 794006 & \\
\hline MFC 1702001 & \\
\hline MFC 1729001 & \\
\hline
\end{tabular}

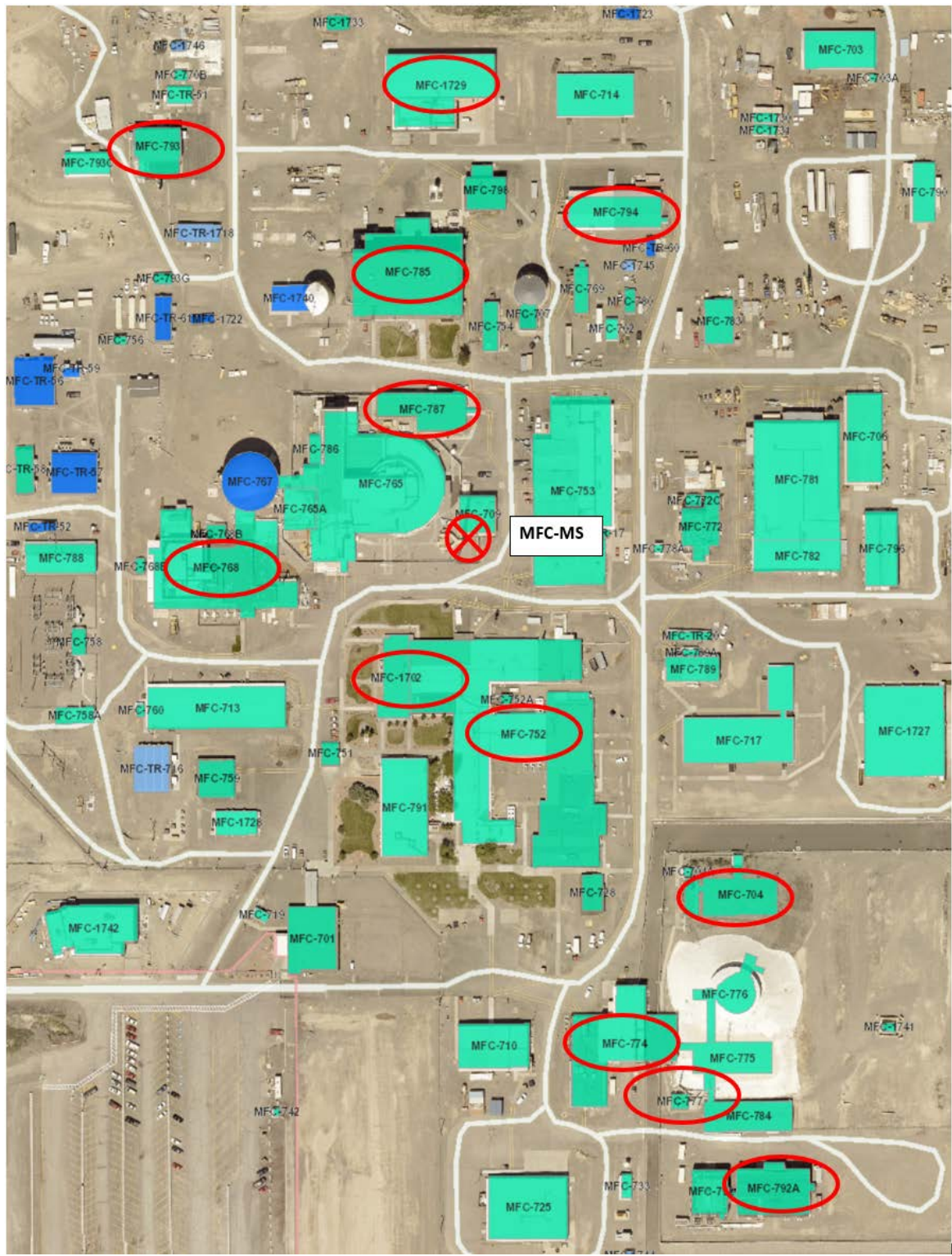


Distances to site \#31

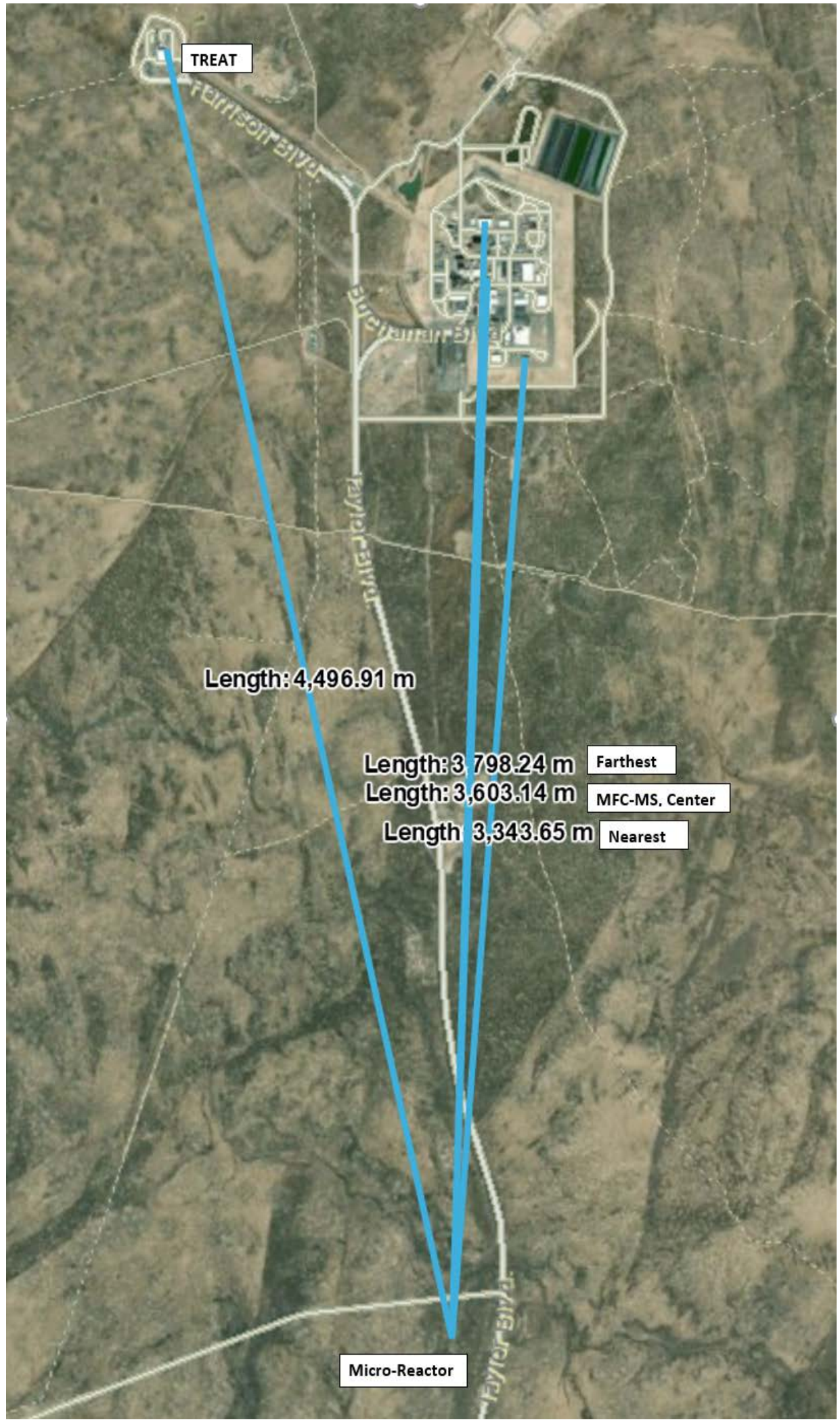


Dose Results at \#31 site

\begin{tabular}{|l|c|c|c|c|}
\hline Source & $\begin{array}{c}\text { Distance to } \\
\text { \#31 Site }(\mathrm{m})\end{array}$ & $\begin{array}{c}\text { Direction } \\
\text { from } \\
\text { Source }\end{array}$ & $\begin{array}{c}\text { Abated } \\
\text { Dose } \\
\text { (mrem/yr) }\end{array}$ & $\begin{array}{c}\text { Unabated } \\
\text { Dose } \\
\text { (mrem/yr) }\end{array}$ \\
\hline MFC-TREAT & 4500 & SSE & $9.6 \mathrm{E}-04$ & NA \\
\hline MFC-MS & 3600 & S & $5.4 \mathrm{E}-08$ & NA \\
\hline MFC-Others & 3600 & S & $1.7 \mathrm{E}-02$ & NA \\
\hline MFC-HALEU & 3600 & S & $6.0 \mathrm{E}-07$ & 6.6 \\
\cline { 3 - 5 } & & Total & $1.8 \mathrm{E}-02$ & 6.6 \\
\cline { 3 - 5 }
\end{tabular}

